\title{
Commercial Light Water Reactor -Tritium Extraction Facility Process Waste Assessment (Project S-6091)
}

\author{
RECORDS ADMINISTRATION
}

by

R. H. Hsu

Westinghouse Savannah River Company Savannah River Site

Aiken, South Carolina 29808

A. O. Delley

RECEVED

MAR 27998

OSTI

G. J. Alexander

R. A. Malstrom

B. R. Nobles

E. A. Clark

S. D. Carson

Sandi National Laboratories

NM USA

P. K. Peterson

Sandi National Laboralories

NM

USA

R. N. Lutz

\section{INFORMATION ONLY}

MASTER

ESTRIBUTON OF nTIS DOCUMLNT is UNLMTIED

DOE Contract No. DE-AC09-89SR18035

This paper was prepared in connection with work done under the above contract number with the U.S. Department of Energy. By acceptance of this paper, the publisher and/or recipient acknowledges the U.S. Government's right to retain a nonexclusive, royalty-free license in and to any copyright covering this paper, along with the right to reproduce and to authorize others to reproduce all or part of the copyrighted paper. 


\title{
WSRC-TR-96-0294 \\ Project S-6091
}

Commercial Light Water Reactor - Tritium Extraction Facility

Process Waste Assessment (U)

(Waste Assessment and Treatment and Disposal Option Assessment)

\section{Rev. 1}

November 30, 1997

\author{
Savannah River Technology Center \\ Westinghouse Savannah River Company \\ Aiken, SC 29808
}




\section{DISCLAIMER}

This report was prepared as an account of work sponsored by an agency of the United States Government. Neither the United States Government nor any agency thereof, nor any of their employees, makes any warranty, express or implied, or assumes any legal liability or responsibility for the accuracy, completeness, or usefulness of any information, apparatus, product, or process disclosed, or represents that its use would not infringe privately owned rights. Reference herein to any specific commercial product, process, or service by trade name, trademark, manufacturer, or otherwise does not necessarily constitute or imply its endorsement, recommendation, or favoring by the United States Government or any agency thereof. The views and opinions of authors expressed herein do not necessarily state or reflect those of the United States Government or any agency thereof.

This report has been reproduced directly from the best available copy.

Available to DOE and DOE contractors from the Office of Scientific and Technical Information, P.O. Box 62, Oak Ridge, TN 37831; prices available from (615) 576-8401.

Available to the public from the National Technical Information Service, U.S. Department of Commerce; 5285 Port Royal Road, Springfield, VA 22161. 


\section{DISCLAIMER}

Portions of this document may be illegible electronic image products. Images are produced from the best available original document. 


\section{WSRC-TR-96-0294}

\section{Project S-6091}

\section{Commercial Light Water Reactor - Tritium Extraction Facility}

Process Waste Assessment (U)

(Waste Assessment and Treatment and Disposal Option Assessment)

Rev. 1

November 30, 1997

Prepared by:

R. H. Hsu

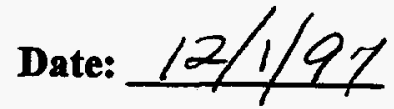

Chemical \& Hydrogen Technology, SRTC

Reviewed by:
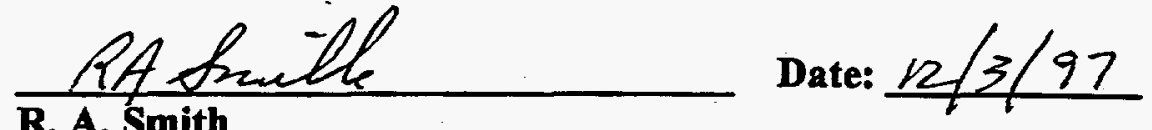

CLWR-Tritium Extraction Facility Project

Approved by:

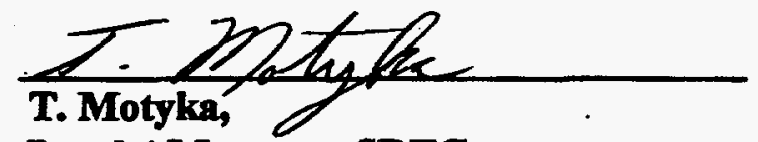

Date: $12 / 18 / 97$

Level 4 Manager, SRTC

Approved by:
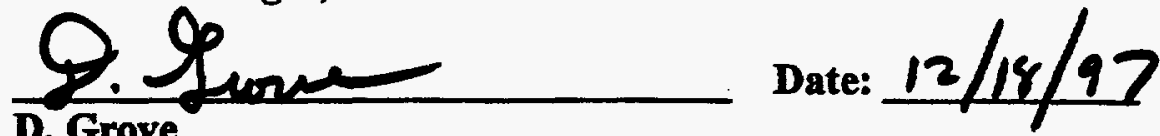

PE \& CD Manager, CLWR-TEF Project

Classification Reviewed by: T. MO TY KA

$$
\begin{gathered}
\text { UNCLASJIFIEO } \\
12 / 1 / 97
\end{gathered}
$$




\section{WSRC-TR-96-0294}

\section{Project S-6091}

Commercial Light Water Reactor - Tritium Extraction Facility

Process Waste Assessment

\section{CO-AUTHORS}

Susan D. Carson

Phyllis K. Peterson

Sandia National Laboratories-New Mexico Albuquerque, New Mexico 87185

\section{CONTRIBUTORS}

Elliot A. Clark

G. Jack Alerander Alexcia O. Delley Jeffrey S. Holder Rex N. Lutz

Robert A. Malstrom

Billie R. Nobles

Anita S. Poore

Paul J. Rowan

Don F. Sink

Westinghouse Savannah River Company

Aiken, SC 29808 


\section{List of Acronyms and Abbreviations}

\begin{tabular}{|c|c|}
\hline $\mathrm{Ag}$ & Silver \\
\hline Al & Aluminum \\
\hline AlNiCo & Aluminum-Nickel-Cobalt \\
\hline ALARA & As Low As Reasonably Achievable \\
\hline APT & Accelerator Production of Tritium \\
\hline Ar & Argon \\
\hline ASTM & American Society of Testing and Materials \\
\hline $\mathbf{B a}$ & Barium \\
\hline BDAT & Best Demonstrated Available Technology \\
\hline BNL & Brookhaven National Laboratory \\
\hline $\mathbf{C}$ & Carbon \\
\hline${ }^{\circ} \mathrm{C}$ & Celsius degree (unit of temperature) \\
\hline CAI & Controlled Air Incinerator \\
\hline CAM & Continuous Air Monitor \\
\hline $\begin{array}{l}\mathrm{cc} \\
\mathrm{Cd}\end{array}$ & $\begin{array}{l}\text { Cubic centimeter } \\
\text { Cadmium }\end{array}$ \\
\hline CERCLA & $\begin{array}{l}\text { Comprehensive Environmental Responsibility, Compensation, } \\
\text { and Liability Act of } 1981\end{array}$ \\
\hline CFC & Chloroflurocarbon \\
\hline cfm & Cubic Feet per Minute \\
\hline CFR & Code of Federal Regulations \\
\hline $\mathbf{C i}$ & Curies \\
\hline CIF & Consolidated Incineration Facility (at SRS) \\
\hline CLWR & Commercial Light Water Reactor \\
\hline CLWR-TEF & Commercial Light Water Reactor-Tritium Extraction Facility \\
\hline COBRA & COmputerized (Radioactive Waste) Burial Record Analysis (at SRS) \\
\hline Cr & Chromium \\
\hline CRM & Count Rate Meter \\
\hline $\mathrm{Cu}$ & Copper \\
\hline D & Deuterium Isotope of Hydrogen \\
\hline D\&D & Decontamination \& Decommissioning \\
\hline DCF & Design Change Form \\
\hline DCS & Distributed Control System \\
\hline $\mathrm{D}_{2} \mathrm{O}$ & Deuterium Oxide (Heavy Water) \\
\hline DOE & Department of Energy \\
\hline DOP & Dioctyl phthalate (used to check HEPA filter efficiency) \\
\hline dpm & Disintegrations per Minute \\
\hline DSSI & Diversified Scientific Services, Inc. (Oak Ridge, TN) \\
\hline $\begin{array}{l}\text { DWPF } \\
\text { EAV }\end{array}$ & Defense Waste Processing Facility (Vitrification Facility at SRS) \\
\hline
\end{tabular}


EIS

EPA

ES\&H

ETF

of

FDD

FFCA

$\mathrm{ft}$

FY

gpm

$\mathbf{H}$

He-3

HEPA

$\mathrm{Hg}$

HIW

HTO

HVAC

HW/MW DF

I. D.

IINTV

ILTV

IIV

INEL

ITP

JCW

${ }^{\circ} \mathrm{K}$

KD-0

$\mathrm{kg}$

1

LANA

LANL

lb

LDR

LiAl

LLW

$\mathrm{m}^{3}$

$\mathbf{M g}$

$\min$

$\mu \mathrm{Ci} / \mathrm{cc}$

MLLW

mrem

$\mathrm{Na}$

NEPA
Environmental Impact Statement

Environmental Protection Agency

Environmental, Safety \& Health

Effluent Treatment Facility (Liquid Waste Treatment Facility at SRS)

Fahrenheit degree (unit of temperature)

Facility Design Description

Federal Facilities Compliance Act of 1992

foot or feet

Fiscal Year

Gallons per Minute

Hydrogen (Protium Isotope)

Helium-3

High Efficiency Particulate Air (Filter)

Mercury

High-Level Waste

Hydrogen Tritium Oxygen (Tritiated water)

Heating, Ventilation and Air Conditioning

Hazardous Waste/Mixed Waste Disposal Facility (at SRS)

Inside diameter

Intermediate Level Non-Tritium Vaults (part of SRS IIV)

Intermediate Level Tritium Vaults (part of SRS IIV)

Intermediate Level Vaults (part of SRS E-Area Vaults)

Idaho National Engineering Laboratory

In-Tank Precipitation (Liquid waste pre-treatment facility for DWPF)

Job Control Waste

Degree Kelvin

Key Decision Zero

kilogram or 1000 gram (unit of mass)

liter

LAnthanum Nickel Aluminum (Metal Hydride Bed Fill Material)

Los Alamos National Laboratory

pound

Land Disposal Restriction

Lithium Aluminum

Low-Level Waste

Lead Test Assembly

Cubic Meters

Magnesium

minute

Micro $\left(10^{-5}\right)$ Curies per cubic centimeter

Mixed Low-Level Waste

millirem (absorbed radiation dose)

Sodium

National Environmental Policy Act of 1969 
NESHAP

$\mathrm{Ni}$

NPDES

NPR

NRC

NTS

O. D.

$\mathrm{Pb}$

Pd

PICs

psig

Pt

PFR

$\mathrm{pCi} / \mathrm{ml}$

PNNL

PPOA

PPE

PVC

P-V-T-C

PWA

PWR

QA

RBOF

RCRA

RHR

RMA

RMERC

RTF

$S \& S$

SCDHEC

SDD

SEG

SNL-NM

SpG

SRS

SRTC

T

TBD

TCAP

TCLP

TEF

TFM\&C
National Emission Standards for Hazardous Air Pollutants

Nickel

National Pollutant Discharge Elimination System

New Production Reactor

Nuclear Regulatory Commission

Nevada Test Site

Outside diameter

Lead

Palladium

Products of Incomplete Combustion

Pounds per square inch gauge

Platinum

Plug Flow Reverser

Pico $\left(10^{-12}\right)$ Curies per milliliter

Pacific Northwest National Laboratory

Pollution Prevention Opportunity Assessment

Personal Protective Equipment

Poly(vinyl chloride)

Pressure-Volume-Temperature-Composition (Tritium accountability method)

Process Waste Assessment

Pressurized Water Reactor

Quality Assurance

Receiving Basin for Off-site Fuel (at SRS)

Resources Conservation and Recovery Act of 1976

Residual Heat Removal

Radiological Materials Area

Retorting or Roasting of Mercury

Replacement Tritium Facility, SRS Building 233-H

Safeguards and Security

South Carolina Department of Health and Environmental Control

System Design Description

Scientific Ecology Group (Oak Ridge, TN)

Sandia National Laboratories - New Mexico

Specific Gravity

Savannah River Site

Savannah River Technology Center

Tritium Isotope of Hydrogen

To Be Determined

Thermal Cycling Absorption Process (Method for hydrogen isotopic separation)

Toxicity Characteristic Leaching Procedure (e.g., EPA Method 1311)

Tritium Extraction Facility

Tritium Facilities Modernization and Consolidation (Project) 
TOC

TPBAR

TRU

TRU Waste

TSCA

TSD

TSTA

U

UPS

VOC

vol

WAC

WERF

WIPP

WITS

WM

WRAP

WSRC

Z-Bed
Total Organic Carbon

Tritium Producing Burnable Absorber Rod

Transuranic (e.g. Pu)

Transuranic Waste

Toxic Substances Control Act (40CFR761)

Treatment, Storage, and Disposal (waste management facility)

Tritium Systems Test Assembly (at LANL)

Uranium

Uninterruptible Power Supply

Volatile Organic Compounds

Volume

Waste Acceptance Criteria

Waste Experimental Reduction Facility (at INEL)

Waste Isolation Pilot Plant (TRU Waste Disposal Facility in New Mexico)

Waste Information Tracking System (at SRS)

Waste Management

Waste Receiving and Processing Facilities (at Hanford)

Westinghouse Savannah River Company

Zeolite Bed 


\section{Table of Contents}

1. Introduction 1

2. Purpose 1

3. Background 2

4. Methodology 2

4.1 Process Definition 3

4.2 Process Characterization 3

4.3 Waste Minimization Assessment 4

4.4 Waste Treatment and Disposal 4

5. Summary 5

5.1 Process Waste Streams 5

$\begin{array}{lll}5.2 & \text { Contaminant Sources. } & 7\end{array}$

5.2.1 Irradiated TPBARs 7

5.2.2 "Crud" Reactor Corrosion Products 8

5.2.3 Tritium 11

5.3 Waste Treatment and Disposal . 11

5.3.1 Waste Treatment 11

5.3.2 Waste Disposal 13

5.4 PWA Critical Assumptions 13

5.5 Challenging Waste Streams and Waste Management Issues 15

5.5.1 Spent TPBAR/Crud Characterization 15

5.5.2 Tritiated Liquid Waste 15

5.5.3 Tritium Permeation and Quantification 15

5.5.4 Waste Classification/Greater-Than-Class C 16 


\subsubsection{CLWR-TEF Process Technology Uncertainties}

5.6 Waste Minimization Technologies and Process Development

6. Conclusions

7. References

Appendix A, CLWR-TEF Processes and Operations

A1. Cask/TPBAR Receiving, Decontamination, Handling and Storage

A2. Tritium Extraction

A3. Tritium Processing

A4. Tritium Process Confinement and Clean-up Systems

A5. Tritium Analysis and Accountability

A6. Balance of Plant Facilities

A-13

Appendix B, CLWR-TEF Hazardous, Low-Level and Mixed Waste Streams

B-1

B1. Job Control Waste (H-3)

B-5

B1a. Nonhazardous Solvent

B-8

B2. Job Control Waste (Depleted Uranium)

B-9

B3. Job Control Waste (Extraction)

B4. Job Control Waste (Mixed Low-Level Waste)

B5. Nonhazardous Process Equipment (H-3)

B5a. Uranium/Magnesium Beds

B5b. Hydride/Catalyst/Zeolite Beds

B6. Spent TPBARs (Extraction)

B6a. TPBAR Baseplates

B7. Failed Furnace Components (Extraction)

B7a. Nonhazardous Process Equipment (Extraction)

B8. HEPA Filters (Extraction) 
B11. Mixed Waste Solvent Rags

B12. Analytical Laboratory/Rad Con Chemicals

B13. Nonhazardous Tritiated Oil

B13a. Glovebox Bubbler Fluid

B14. Tritiated Water and Aqueous Solutions

B15. Teledyne Oxygen Sensor Micro-Fuel Cells

B16. Palladium/Electrolysis Membrane

B17. Ion Exchange Resin Beds

Absorbent Wipes (See B1,B2,B3, B4)

Analytical Cocktails (See B14)

Analytical Laboratory Chemicals (See B12)

Batteries, Ni-Cd and Lead Acid (See B9)

Beds, Catalyst (See B5b)

Beds, Hydride (See B5b)

Beds, Ion Exchange Resin (See B17)

Beds, Magnesium (See B5a)

Beds, Uranium (See B5a)

Beds, Zeolite (See B5b)

Catalytic Cracker (See B5b)

Confinement Boxes/Parts (See B7a)

Cranes/Parts/Cables (See B7a)

Diffusers, Pd-Ag (See B9)

Electrolysis Membrane (See B16)

Extraction Container Lids (See B7a)

Filters, Building HEPA (See B8)

Filters, Extraction (See B7a)

Furnace Cover (See B7)

Furnace Heating Elements (See B7)

Furnace HEPA Filter (See B8)

Gaskets (See B1,B3,B4,B7)

Gauges (See B5,B7a)

Gloves, Butyl Rubber (See B1,B2,B3,B4)

Gloves, Latex (See B1,B3,B4)

Glovebox Parts (See B5, B7a)

Glovebox Bubbler Fluid (See B13a)

Instrumentation (See B5,B7a,B9) 
Light bulbs, Fluorescent (See B9)

Metals, Shielding (See B7a,B9)

Oil (See B10,B13)

Paint Shop Waste (See B1,B3,B4)

Paper, Kraft (See B1,B2,B3,B4)

Photographic Waste (See B4)

Plastic Bags (See B1,B2,B3,B4)

Plastic Sheeting (See B1,B2,B3,B4)

Plastic Shoe Covers (See B1,B2,B3,B4)

Plastic Suits/Air Hoses (See B1,B3,B4)

Pneumatic Cutter/Parts (See B7a)

Pumps, Nometex (See B5)

Pumps, Vacuum (See B5)

Rad Con Chemicals (See B12)

Solvent Rags, Wipes (See B1,B2,B3,B4)

Solvent, Spent (See Bla,B10)

Stainless Steel Tanks/Piping (See B5,B7a)

TPBAR, Spent (See B6)

TPBAR Baseplates (See B6a)

TPBAR Extraction Baskets (See B6)

Transporters/Parts (See B7a)

Valves (See B5,B10)

Video Camera/Parts (See B7a)

Water, Cask Decon (See B14)

Water, Process Cooling (See B14)

Welding Waste (See B1, B3,B4) 
Appendix C, Treatment and Disposal of CLWR-TEF Waste

C1. CLWR-TEF Waste Disposition

C-3

C1.1 Low-Level Waste

C-3

C1.2 Mixed Low-Level Waste

C-6

C1.3 Hazardous Waste

C-7

C2. Existing and Planned SRS Waste Treatment Facilities

C2.1 E-Area Vaults

C2.2 Consolidated Incineration Facility

C-8

C2.3 Hazardous/Mixed Waste Storage Pads/Buildings

C-9

C2.4 Sanitary Landfill

C-9

C2.5 Effluent Treatment Facility

C-9

C2.6 Sanitary Sewage Treatment Facility

C-10

C2.7 Hazardous Waste/Mixed Waste Disposal Facility

C-10

C2.8 Prohibited Wastes

C-11

C3. Other DOE and Commercial Waste Treatment Facilities

C3.1 Hanford

C3.2 Nevada Test Site

C-14

C3.3 Scientific Ecology Group (SEG)

C3.4 Diversified Scientific Services, Inc. (DSSI)

C3.5 Envirocare

C3.6 GTS Duratek

C4. Treatment Technologies

C4.1 Compaction

C4.2 Thermal Desorption

C4.3 Incineration

C4.4 Stabilization 
C4.5 Vitrification

C-19

C4.6 Encapsulation

C-19

C4.7 Metals Recovery

C-20

Appendix D, Waste Stream Inventory by Waste Type

D-1

Appendix E, Waste Stream Inventory - EIS Format

E-1

Appendix F, Waste Stream Inventory by Waste Treatment Category

F-1

Appendix G, EPA Hazardous Waste Codes with Subcategories

G-1 


\section{List of Tables}

$\begin{array}{lll}\text { Table 1 } & \text { Estimated Annual Waste Generation Rates for CLWR-TEF } & 6 \\ \text { Table 2 } & \text { Radionuclide Characteristics of CLWR TPBAR } & 9 \\ \text { Table 3 } & \text { Treatment/Disposal Options for CLWR-TEF Waste } & 12 \\ \text { Table 4 } & \text { NRC Greater-Than-Class C Radionuclide Limits } & 17 \\ \text { Table B1 } & \text { SRS FY97-98 Tritium Waste Forecast } & \text { B-4 } \\ \text { Table B2 } & \text { Radionuclide Characteristics of CLWR TPBAR } & \text { B-23 } \\ \text { Table C1 } & \text { Existing and Planned DOE Waste Treatment Facilities } & \\ & \text { Relevant for CLWR-TEF Waste } & \text { C-12 } \\ \text { Table G1 } & \text { EPA Hazardous Waste Indexes } & \text { G-2 }\end{array}$

\section{List of Figures}

Figure A-1 CLWR-TEF Process Schematic

A-3

Figure C-1 CLWR-TEF Waste Management Facilities

C-5 
[This Page Intentionally Left Blank] 


\section{Introduction}

The Savannah River Site (SRS) has been tasked by the Department of Energy (DOE) to design and construct a Tritium Extraction Facility (TEF) to process irradiated tritium producing burnable absorber rods (TPBARs) from a Commercial Light Water Reactor (CLWR). The plan is for the CLWR-TEF to provide tritium to the SRS Replacement Tritium Facility (RTF) in Building 233-H in support of DOE requirements. The CLWR-TEF is being designed to provide $3 \mathrm{~kg}$ of new tritium per year, from TPBARS and other sources of tritium (Ref. 1-4).

The CLWR TPBAR concept is being developed by Pacific Northwest National Laboratory (PNNL). The TPBAR assemblies will be irradiated in a Commercial Utility light water nuclear reactor and transported to the SRS for tritium extraction and processing at the CLWR-TEF. A Conceptual Design Report for the CLWR-TEF Project was issued in July 1997 (Ref. 4).

The scope of this Process Waste Assessment (PWA) will be limited to CLWR-TEF processing of CLWR irradiated TPBARs. Although the CLWR-TEF will also be designed to extract APT tritium-containing materials, they will be excluded at this time to facilitate timely development of this PWA As with any process, CLWR-TEF waste stream characteristics will depend on process feedstock and contaminant sources. If irradiated APT tritium-containing materials are to be processed in the CLWR-TEF, this PWA should be revised to reflect the introduction of this contaminant source term.

\section{Purpose}

DOE has made a commitment for the Commercial Light Water Reactor Tritium Extraction Facility project to comply with all applicable environmental regulatory requirements. In this respect, it is important to consider and design all tritium extraction processing alternatives so that they can comply with these requirements. The management of waste is an integral part of this activity and it is therefore necessary to estimate the quantities and specific wastes that will be generated by the CLWR-TEF. A thorough assessment of waste streams includes waste characterization, quantification, and the identification of treatment and disposal options. This PWA provides waste stream characterization and quantification information required to meet the waste generation and waste minimization requirements defined in 40 CFR 268 (Land Disposal Restrictions), 40 CFR 260-5, DOE Orders 5820.2A, 6430.1A, and the 5400.xx and 5480.xx series. It is based on the format of a PWA developed in 1994 by Sandia National LaboratoriesNew Mexico (SNL-NM) for the APT (Ref. 6) and is intended to provide partial data for an Environmental Impact Statement (EIS) such as in Ref. 7-8. (Note: The periodic PWAs conducted by Operating Facilities at SRS are being renamed Pollution Prevention Opportunity Assessments (Ref. 9). However, for consistency with the APT Process Waste Assessment, the Process Waste Assessment title is being retained for this study.) 
The management and ultimate disposal of waste is a costly and complicated activity involving established internal procedures, permitting, and other regulatory issues. The costs and lead times associated with these issues should be estimated and considered along with other design and engineering costs. This PWA provides data for cost-benefit analysis of the potential environmental impact of the CLWR-TEF, is an integral part of waste minimization, and is required by DOE for any activity that will generate radioactive, hazardous, and mixed wastes. It will also better position the CLWR-TEF to meet future requirements, since it is anticipated that regulatory and other requirements will continue to become more restrictive and demanding.

A PWA is also essential for the evaluation of the design or technology options proposed for the CLWR-TEF. A key factor in TPBAR extraction technology and other design feature selection is the assessment of waste streams and quantities produced. Waste stream analysis will demonstrate whether advantages in terms of waste volumes and characteristics may result from the use of a certain technology and/or design features.

\section{Background}

The DOE is responsible for research, development, and testing of nuclear weapons for the Department of Defense. These responsibilities include production of certain critical materials required for the weapons. One such material is tritium, a gaseous isotope of hydrogen used to enhance the explosive power of nuclear warheads. Tritium is radioactive, and about 5.5 percent is lost each year through natural decay (12.3 years half-life). Because of this loss, existing weapons must be re-supplied periodically with tritium in order to maintain their effectiveness.

In the 1950's, DOE began producing tritium in nuclear reactors located at the Savannah River Site near Aiken, South Carolina. Concerns about operational safety led DOE to shut down these reactors in 1988. Two primary alternatives are now being considered for meeting future requirements for tritium production: 1) Accelerator Production of Tritium, and 2) Commercial Light Water Reactor production of tritium using lithium aluminate TPBARs and shipment of the irradiated TPBARs to a Tritium Extraction Facility to extract and purify the tritium. DOE started funding the Conceptual Design for the CLWR-TEF Project (S-6091) in 1996. The proposed CLWR-TEF is to be built at SRS. It has some attributes of a nuclear reactor facility, e.g., processing of irradiated target rods with significant radiation levels and decay heat. However, the CLWR-TEF is not expected to introduce or process materials that could lead to criticality issues and there will be no generation of high-level waste (HLW) from reprocessing of spent TPBARs.

\section{Methodology}

This PWA is concerned with characterization of all waste streams generated during normal operation of the CLWR-TEF to extract and purify tritium from irradiated CLWR TPBARs. Because the CLWR-TEF facility design is only in the pre-conceptual design phase, waste streams generated at the end of the life of the facility during the decontamination and decommissioning (D\&D) and wastes from accidents are not examined in depth. Sanitary sewage and wastewater are generated based on CLWR-TEF staffing estimates. Qualitative and quantitative assessments were performed for all other process-specific waste streams, and non-process activities such as 
maintenance and repair. The envelope examined includes all processing steps from receipt of irradiated CLWR TPBAR through the actual processing of tritium to produce tritium of the desired purity.

There are four parts to this PWA: process definition, process characterization, waste minimization assessment, and waste treatment and disposal. "Process" is used broadly here to include any operation that generates a waste or pollutant, or uses a hazardous or radioactive material.

\subsection{Process Definition}

Process definition briefly describes the overall operations and the specific processes or operations that consume or generate sanitary, hazardous and/or radioactive materials or wastes. Each of these processes is discussed in Appendix A, CLWR-TEF Processes and Operations. A simplified process schematic for the CLWR-TEF is also given in Appendix A. For this discussion, CLWRTEF processes were organized into six segments:

- TPBAR/Cask Receipt, Decontamination, Handling and Storage

- Tritium Extraction

- Tritium/Product Processing

- Tritium Process Confinement and Clean-Up Systems

- Tritium Analysis and Accountability

- Balance of Plant Facilities

\subsection{Process Characterization}

Process characterization collects information about the quantity and nature of the hazardous and/or radioactive materials used in tritium extraction and purification processes and the wastes and other pollutants generated. This information was obtained from a variety of sources such as experience of existing SRS and LANL tritium facilities, projected levels of production activities, and engineering estimates. Most CLWR-TEF processes are still in the conceptual design stage and the information needed for a complete characterization is not yet available. Several wastes identified are not the result of a process, but rather are from site-wide maintenance of process equipment or from failure of process equipment and components through usage or exposure to harsh environments. Wastes from all processes were grouped into waste streams with similar characteristics and modes of generation.

Appendix B provides the following information for each of 19 identified CLWR-TEF waste streams that may contain hazardous and/or radioactive constituents:

Type: Identifies a solid waste stream as either hazardous waste, low-level radioactive waste, intermediate-level waste or mixed low-level waste. Intermediate-level waste is a subset of lowlevel waste; it is used to designate low-level waste associated with spent irradiated CLWR TPBARs that emit greater than $200 \mathrm{mRad} / \mathrm{hr}$ closed window reading at $5 \mathrm{~cm}$ from the container surface. Radioactive liquid waste streams are also identified. No high-level or transuranic waste is expected to be generated by the CLWR-TEF. 
Description: Waste stream physical matrix, chemical composition, RCRA components and hazardous waste codes present, and anticipated radioactive isotopes and activity levels.

Generation: A description of the processes or activities that generate the waste stream.

Handling and Packaging A description of current or recommended handling and packaging techniques for the waste stream.

Annual Quantities: Estimated annual generation rates in both mass and volume. Quantities are based on experience of DOE facilities with similar operations or using similar components, assumed levels of production activities and engineering judgment.

Treatment Options: lists possible treatment technologies for LLRW or MLLW waste stream. Descriptions of the listed treatment technologies are given in Appendix C. It is assumed that hazardous waste which cannot be incinerated in the CIF will be packaged for treatment and/or disposal at a DOE-approved DOE or commercial waste management facility. One notable exception is corrosive-only hazardous waste that must be treated by the waste generator before disposal.

Comments: Provides additional information pertinent to understanding the nature of the waste stream or its treatment that do not fit in with other categories.

\subsection{Waste Minimization Assessment}

The waste minimization assessment identifies and evaluates various alternatives for reducing or eliminating the waste stream, or for eliminating either the hazardous or radioactive component in the mixed low-level waste. A detailed understanding of how hazardous materials are used and wastes are generated in the process is critical to the success of this effort. Waste minimization is addressed under a separate sub-heading for each waste stream listed in Appendix B.

\subsection{Waste Treatment and Disposal}

CLWR-TEF wastes will need to be managed for treatment and disposal according to waste type; i.e., sanitary, hazardous, low-level, or mixed low-level waste, in accordance with the requirements of DOE Order 5820.2A and other applicable DOE Orders. At SRS, operating divisions must provide a facility Waste Certification Plan to Solid Waste for approval. The Waste Certification Plan and individual waste stream characterization plans must be approved, and the Waste Management Facility Waste Acceptance Criteria must be met before waste can be shipped to the Solid Waste Management Division for treatment, storage and/or disposal (Ref. 10).

Waste treatment options that currently exist or are expected to be available by the time the CLWR-TEF facility is built are listed for each waste stream in Appendix B. If more than one treatment method is feasible for a particular waste stream, no attempt is made to prioritize or recommend specific treatments; such recommendations would necessarily be based on costbenefit analyses, trade studies and risk assessments that would be performed at a later stage of 
design development. If a treatment generates secondary waste that also requires treatment, this is discussed in the context of the primary CLWR-TEF waste stream and the secondary waste is not listed as a separate waste stream.

SRS, DOE, and commercial low-level and mixed waste treatment/disposal facilities are presented in Appendix C, Treatment and Disposal of CLWR-TEF Wastes. Brief descriptions of treatment technologies that are currently available or are expected to be available by the time CLWR-TEF is built are also presented in Appendix C.

\section{Summary}

This PWA was developed based on pre-conceptual and conceptual design information. A final conceptual design of the CLWR-TEF was issued in July 1997. The anticipated waste streams identified and projected quantities reported here reflect design data in the CLWR-TEF Conceptual Design Package of July 8, 1997 (Ref. 4), the CLWR-TEF Facility Design Description of September 22, 1997 (Ref. 3), various CLWR-TEF System Design Descriptions (Refs. 11a-11ff), conceptualized modes of operation, assumed levels of production activities and engineering judgment. Development of this PWA will be an iterative process. The waste stream information should be refined as the design progresses, preferred technologies are selected, operational uncertainties and assumptions are refined and characterizations of contaminant sources are improved.

\subsection{Process Waste Streams}

Radioactive waste in the CLWR-TEF is generated from extraction of CLWR irradiated TPBARs. The irradiated TPBAR assembly baseplates and the post-extraction spent TPBARs constitute the primary, unavoidable waste streams. The irradiated baseplates and spent TPBARs are highly radioactive because they contain several short-lived gamma radionuclides, in addition to tritium, a beta emitter. Extraction gases containing tritium undergo further purification to produce tritium of the desired purity. Post-extraction tritium processing generates waste streams that should only be contaminated with tritium.

Wastes are generated as part of the production process, decontamination process, analytical activities, and operation of supporting facilities. They are also generated incidentally through failed equipment, routine maintenance and due to off-normal events.

Seventeen CLWR-TEF waste streams have been identified and are described in Appendix B. Estimates of the annual uncompacted, containerized waste generation rates by waste type, mass and volume are summarized from Appendix B and presented in Table 1. A similar table has been developed for the Environmental Impact Statement (EIS) Input Submittal report. In addition to waste classification according to waste type (low-level, hazardous or mixed), data in the EIS are broken out by waste source; i.e., tritium extraction or tritium processing waste. A summary of waste stream data by waste type is provided in Appendix D and EIS summary data are presented in Appendix E. 
Table 1. Estimated Annual Waste Generation Rates for the CLWR-TEF

\begin{tabular}{|l|r|r|r|}
\hline \multicolumn{1}{|c|}{ Waste Type } & $\begin{array}{c}\text { Mass } \\
\mathbf{k g} / \mathbf{y r}\end{array}$ & $\begin{array}{c}\text { Volume } \\
\mathbf{m}^{\mathbf{3} / \mathbf{y r}}\end{array}$ & $\begin{array}{c}\text { Avg Waste } \\
\text { Density } \\
\mathbf{k g} / \mathbf{m}^{\mathbf{3}}\end{array}$ \\
\hline Transuranic Waste & 0 & 0 & - \\
\hline High-Level Waste & 0 & 0 & - \\
\hline Low-Level Radioactive Waste & 90,170 & 420 & 214 \\
\hline Hazardous Waste & 1,260 & 1.3 & 966 \\
\hline Mixed Low-level Waste & 790 & 5 & 158 \\
\hline Liquid Sanitary Sewage & $7,400,000$ & 7,400 & 1,000 \\
\hline Solid Sanitary Sewage & 24,500 & 165 & 150 \\
\hline
\end{tabular}

The numbers given here should not be considered the total wastes for CLWR-TEF; they are the totals for waste streams that can be quantified at this time. Appendix B has a number of potential waste streams for which the quantities have been neglected at this time, and the numbers presented above do not include contingency for these streams.

Job control waste, primarily personal protection equipment (PPE), from the CLWR-TEF is estimated at $382 \mathrm{~m}^{3} / \mathrm{yr}$, with most of this total assumed to result from extraction activities. Operating data from SRS indicates that the extraction building generally generates about twice as much job control waste as the tritium loading building. However, with a high degree of remotehandled operations expected in the CLWR-TEF and use of confinement systems, there is some uncertainty and the estimate may be conservative. The total estimate for all job control waste streams is $-51,000 \mathrm{~kg} / \mathrm{yr}$ or $\sim 57 \%$ of the total weight and $-90 \%$ of the total volume of radioactive waste generated by the CLWR-TEF. All JCW volumes are for uncompacted, containerized waste.

Job control waste streams for the CLWR-TEF are reduced from current SRS Tritium Facilities baseline forecasts for similar activities based on the expectation that waste minimization initiatives will reduce waste generated by CLWR-TEF start-up by $50 \%$ for comparable activities and on several years of 233-H operating experience at the SRS and over ten years' of operating experience at the LANL Tritium Systems Test Assembly (TSTA). The TSTA is a tritium processing and cryogenic distillation purification facility which has processed approximately 100 $\mathrm{kg}$ of tritium during this period (averaging $10 \mathrm{~kg} / \mathrm{yr}$ ) using triple containment designs. During this ten-year period of continuous facility operation (all of the following statements are from Ref. 12),

- TSTA has never had a spill.

- Glovebox gloves have not needed to be changed.

- Approximately ten pairs of latex gloves have been used.

- Approximately $100 \mathrm{~kg}$ of plastic sheeting has been used.

- Approximately $45 \mathrm{~kg} / \mathrm{yr}$ of plastic bags are used. 
- Plastic shoe covers are used an average of less than once a year.

- Plastic suits and air hoses have never been used.

The CLWR-TEF will be designed to minimize the need for "plastic suit work" and the resulting wastes. Double containment systems such as that used at TSTA (Ref. 13) or the 233-H RTF at SRS (Ref. 14-16) will allow for many maintenance activities to be performed in glove boxes and are expected to minimize waste generation.

\subsection{Contaminant Sources}

The following sections discuss the primary sources of the radioactive and hazardous contaminants found in CLWR-TEF wastes. These sources include the irradiated TPBARs and baseplates, reactor corrosion products that adhere to the TPBARs commonly referred to as "crud", and the tritium product.

\subsubsection{Irradiated TPBARs}

Spent TPBARs, or TPBARs after undergoing extraction to remove tritium, is the primary remotehandled waste stream. It is proposed to dispose of the spent TPBARs in Intermediate Level Tritium Vaults (IITV) silos of the E- Area Vaults (EAV). Both compositional and radionuclide density characterizations are needed to determine if the waste will meet the current EAV Waste Acceptance Criteria or WAC (Ref. 17). Characterization data will be needed for both the Lead Test Assemblies (LTAs) and the TPBAR Production Assemblies (PAs). Idaho National Engineering Laboratory (INEL) has primary responsibility for this issue and is working to obtain both analytical data from bench-scale extractions and modeling or calculational results. The modeling methodology and calculated results must be validated or benchmarked against analytical characterization data.

Note: The composition data for both pre-and post-extraction TPBARs will help determine extraction efficiency. Due to the expected high gamma radioactivity, any irradiated TPBAR analysis must be in small quantities and may require remote-handling analytical capabilities. ALARA and waste minimization considerations suggest that it is highly desirable not to have to physically analyze each TPBAR batch before and after each extraction. Thus, it is very important to develop a reliable calculation technique for determining TPBAR composition. A potential complication is that the modeling methodology and data may have to be classified.

Table 2 gives the calculated radionuclide distribution in one irradiated TPBARs at several time intervals after reactor scram (termination of nuclear reaction) (Ref. 18). These calculations were done by PNNL using the ORIGEN2 code. The more conservative values from tables 4, 6 and 8 of Ref. 18 are used. Disposal of 300 TPBARs in each EAV ILTV silo would exceed the IIV WAC limits for several of the radionuclides (C-14, Ni-59, Tc-99), if the TPBARs are processed and disposed of within one year. (Note: The current Interim WAC3.17 for ILTV silos only have radionuclide limits for $\mathrm{H}-3$ and $\mathrm{CO}-60$ and not the other radionuclides. The author believes this will be corrected and should be similar to the ILV radionuclide limits. The ILTV silo WAC limits were developed for the existing spent melt, under the assumption that there would be minimal activation products. As a result, some of the TPBAR radionuclides in Table 2 were screened out 
and do not appear in the WAC for the ILTV silos. A waste performance assessment for the TPBAR waste must be conducted to make sure that the WAC adequately addresses the spent TPBAR waste for ILTV silo disposal. The Project is proceeding at risk assuming TPBARs may be disposed of in the ILTV silos.)

\subsection{2 "Crud" Reactor Corrosion Products}

Irradiated TPBARs received at the CLWR-TEF are expected to be contaminated with reactor corrosion products which deposit on TPBAR surfaces. This surface coating of reactor pool corrosion products is commonly referred to as "crud" (Ref. 19-20). Crud in spent fuel has been observed in both pools and shipping casks. . Although crud does not easily become airborne, it is a potential source of contamination that will impact storage, handling, and shipping operations, as well as TPBAR preparation for extraction.

The data on potential crud formation on CLWR-irradiated TPBARs is very limited. A study of crud in reactor fuel indicated that the crud in Pressurized Water Reactors consists of activated corrosion products such as magnetite $\left(\mathrm{Fe}_{3} \mathrm{O}_{4}\right)$ and nickel ferrite $\left(\mathrm{Ni}_{2}\left(\mathrm{Fe}_{3}-\mathrm{xO}_{4}\right)\right.$ ), with a metallic composition of about $78 \% \mathrm{Fe}, 20 \%$ nickel and the balance $\mathrm{Co}, \mathrm{Cu}, \mathrm{Zn}, \mathrm{Ni}$ and $\mathrm{Mn}$. Crud composition on stainless steel and Inconel surfaces in a typical Pressurized Water Reactor consists of approximately $70 \% \mathrm{Ni}, 14 \% \mathrm{Fe}, 16 \% \mathrm{Cr}$ and other metals. Crud contains $\mathrm{Co}-60$, the primary source of gamma radiation after several months, but also has $\mathrm{Zn}-65, \mathrm{Mn}-54, \mathrm{Co}-58, \mathrm{Fe}-59$ and Cr-51.

Crud may be black, gray or reddish in color, and may sometimes be confused with the zirconium oxide film, the corrosion product of cladding. Crud may be present in one or two layers, with thickness ranging $1-100 \mu \mathrm{m}$ and density of $\sim 1.2 \mathrm{~g} / \mathrm{cc}$. Crud characteristics will vary from reactor to reactor, cycle to cycle and axial and circumferential location in an assembly. Most crud appears near the top of the reactor core and in regions of low shear flow. Its formation appears to be inversely proportional to axial fuel assembly power. Vibrations during shipping and extended dry storage conditions may lead to loosening and flaking of crud.

Crud may lead to poor heat transfer and fuel overheating during irradiation. In the CLWR-TEF, if it is necessary to remove the crud prior to extraction, a potentially mixed waste stream will be generated. Clean-up of crud contamination in storage and TPBAR preparation areas will also result in low-level job control waste. Residual crud on the TPBAR surfaces, if not volatilized during extraction, will become part of the spent TPBAR waste. Thus, in either case, crud compositional data will be needed for waste characterization. 
Table 2. Radionuclide Characteristics of CLWR TPBAR (CiTPBAR)

\begin{tabular}{|c|c|c|c|c|c|c|c|c|c|}
\hline $\begin{array}{l}\text { Radio- } \\
\text { nuclide }\end{array}$ & Half-Life & $\begin{array}{l}\text { Decay } \\
\text { Mode }\end{array}$ & $\begin{array}{c}7 \\
\text { Days }\end{array}$ & $\begin{array}{c}30 \\
\text { Days }\end{array}$ & $\begin{array}{c}90 \\
\text { Days }\end{array}$ & $\begin{array}{c}180 \\
\text { Days }\end{array}$ & $\begin{array}{c}1 \\
\text { Year }\end{array}$ & $\begin{array}{c}3 \\
\text { Years }\end{array}$ & $\begin{array}{c}10 \\
\text { Years }\end{array}$ \\
\hline $\mathrm{H}-3$ & $12.33 \mathrm{y}$ & Beta & $1.16 \mathrm{E}+04$ & $1.16 \mathrm{E}+04$ & $1.15 \mathrm{E}+04$ & $1.13 \mathrm{E}+04$ & $1.10 \mathrm{E}+04$ & $9.84 \mathrm{E}+03$ & $6.64 \mathrm{E}+03$ \\
\hline C-14 & $5730 y$ & Beta & $8.91 \mathrm{E}-03$ & $8.91 \mathrm{E}-03$ & $8.91 \mathrm{E}-03$ & $8.91 \mathrm{E}-03$ & $8.91 \mathrm{E}-03$ & $8.91 \mathrm{E}-03$ & $8.91 E-03$ \\
\hline $\mathrm{Na}-24$ & $15 \mathrm{~h}$ & Beta & $1.22 \mathrm{E}-03$ & $1.02 \mathrm{E}-14$ & $0.00 \mathrm{E}+00$ & $0.00 \mathrm{E}+00$ & $0.00 \mathrm{E}+00$ & $0.00 \mathrm{E}+00$ & $0.00 \mathrm{E}+00$ \\
\hline $\mathrm{Cr}-51$ & $27.7 \mathrm{~d}$ & Gamma & $4.27 \mathrm{E}+02$ & $2.40 \mathrm{E}+02$ & $5.36 \mathrm{E}+01$ & $5.64 \mathrm{E}+00$ & $5.48 \mathrm{E}-02$ & $6.34 \mathrm{E}-10$ & $\mathrm{E}+00$ \\
\hline Mn-54 & $312.2 d$ & Gamma & $2.06 \mathrm{E}+01$ & $1.96 \mathrm{E}+01$ & $1.72 \mathrm{E}+01$ & $1.41 \mathrm{E}+01$ & $9.32 \mathrm{E}+00$ & $1.84 \mathrm{E}+00$ & $6.35 \mathrm{E}-03$ \\
\hline Fe-55 & $2.73 y$ & e-capture & $1.05 \mathrm{E}+02$ & $1.03 \mathrm{E}+02$ & $9.84 \mathrm{E}+01$ & $9.21 \mathrm{E}+01$ & $8.05 \mathrm{E}+01$ & $4.72 \mathrm{E}+01$ & $\mathrm{E}+00$ \\
\hline $\mathrm{Fe}-59$ & $44.5 \mathrm{~d}$ & Beta/ $y$ & $9.28 \mathrm{E}+00$ & $6.51 E+00$ & $2.59 E+00$ & $6.46 \mathrm{E}-01$ & $3.73 \mathrm{E}-02$ & $4.84 \mathrm{E}-07$ & $3.81 \mathrm{E}-24$ \\
\hline Co-58 & $70.9 \mathrm{~d}$ & Gar & $7.22 \mathrm{E}+01$ & $5.76 \mathrm{E}+01$ & $3.20 \mathrm{E}+01$ & $1.33 \mathrm{E}+01$ & $2.16 \mathrm{E}+00$ & $1.69 \mathrm{E}-03$ & E-14 \\
\hline $\mathrm{Co}-60$ & $5.27 \mathrm{y}$ & Beta/y & $3.22 \mathrm{E}+01$ & $3.20 \mathrm{E}+01$ & $3.13 \mathrm{E}+01$ & $3.03 E+01$ & $2.83 E+01$ & $2.18 E+01$ & $8.67 \mathrm{E}+00$ \\
\hline Ni-59 & $7.6 \mathrm{E} 4 \mathrm{y}$ & e- capture & $2.18 \mathrm{E}-02$ & $2.18 \mathrm{E}-02$ & $2.18 \mathrm{E}-02$ & $2.18 \mathrm{E}-02$ & $2.18 \mathrm{E}-02$ & $8 E-02$ & $\mathrm{E}-02$ \\
\hline $\mathrm{Ni}-63$ & $100 y$ & Beta & $3.52 \mathrm{E}+00$ & $3.52 \mathrm{E}+00$ & $3.52 \mathrm{E}+00$ & $3.51 E+00$ & $3.50 \mathrm{E}+00$ & $3.45 E+\infty 0$ & $2+00$ \\
\hline $\mathrm{Cu}-64$ & $12.7 \mathrm{~h}$ & Beta/y & $7.80 \mathrm{E}-04$ & $6.43 \mathrm{E}-17$ & $0.00 \mathrm{E}+00$ & $0.00 E+00$ & $0.00 \mathrm{E}+00$ & $0.00 \mathrm{E}+00$ & $8+00$ \\
\hline $2 n-65$ & $243.8 \mathrm{~d}$ & Bet & $1.70 \mathrm{E}-03$ & $1.59 \mathrm{E}-03$ & $1.34 \mathrm{E}-03$ & $1.04 \mathrm{E}-03$ & $6.13 \mathrm{E}-04$ & $7.69 \mathrm{E}-05$ & $8-08$ \\
\hline Sr-89 & $50.5 \mathrm{~d}$ & Beta & $2.50 \mathrm{E}-02$ & $1.82 \mathrm{E}-02$ & $8.00 \mathrm{E}-03$ & $2.33 \mathrm{E}-03$ & $1.83 \mathrm{E}-04$ & 8.09E-09 & $E-24$ \\
\hline Y-89m & $15.7 \mathrm{~s}$ & IT & $2.80 \mathrm{E}-04$ & $2.13 E-06$ & $6.35 \mathrm{E}-12$ & $3.27 \mathrm{E}-20$ & $0.00 \mathrm{E}+00$ & $0.00 \mathrm{E}+00$ & +00 \\
\hline$Y-90$ & $2.67 d$ & Beta & $1.68 \mathrm{E}-01$ & $4.26 \mathrm{E}-04$ & $6.42 \mathrm{E}-07$ & $6.39 \mathrm{E}-07$ & $6.31 \mathrm{E}-07$ & $6.02 \mathrm{E}-07$ & E-07 \\
\hline Y-91 & $58.5 \mathrm{~d}$ & Beta & $6.42 \mathrm{E}-02$ & $4.89 \mathrm{E}-02$ & $2.40 \mathrm{E}-02$ & \begin{tabular}{|l|l|}
$8.27 \mathrm{E}-03$ \\
\end{tabular} & 9.21E-04 & $1.61 \mathrm{E}-07$ & $\mathrm{E}-20$ \\
\hline $\mathrm{Zr}-89$ & $3.27 \mathrm{~d}$ & $\begin{array}{l}e-c \\
\text { Bet }\end{array}$ & $2.80 \mathrm{E}-04$ & $2.14 \mathrm{E}-06$ & $6.36 \mathrm{E}-12$ & $3.27 \mathrm{E}-20$ & $3-37$ & $\mathrm{E}+00$ & +00 \\
\hline $\mathrm{Zr}-93$ & $0 y$ & $\mathrm{Be}$ & -04 & $1.07 \mathrm{E}-04$ & E-04 & & -04 & $E-04$ & $x-04$ \\
\hline $2 r-95$ & $64 d$ & Beta & $2.94 \mathrm{E}+01$ & $2.29 \mathrm{E}+01$ & $1.20 \mathrm{E}+01$ & $4.51 E+00$ & $6.06 \mathrm{E}-01$ & $2 \mathrm{E}-04$ & $8-16$ \\
\hline Zr-97 & & Beta/y & $E-02$ & $7.75 \mathrm{E}-12$ & $0.00 \mathrm{E}+00$ & $0.00 \mathrm{E}+00$ & $0.00 \mathrm{E}+00$ & $\mathrm{E}+00$ & +00 \\
\hline $\mathrm{Nb}-92$ & $3.6 \mathrm{E}+7 \mathrm{y}$ & $\mathrm{Gan}$ & $1.57 \mathrm{E}-01$ & $3.27 \mathrm{E}-02$ & $5.45 \mathrm{E}-04$ & $1.18 \mathrm{E}-06$ & $3.81 E-12$ & $6 \mathrm{E}-34$ & +00 \\
\hline $\mathrm{Nb}-93 \mathrm{~m}$ & $16.1 y$ & $\mathbf{I T}$ & $3.78 \mathrm{E}-06$ & $4.10 \mathrm{E}-06$ & $4.91 \mathrm{E}-06$ & $6.12 \mathrm{E}-06$ & $8.57 \mathrm{E}-06$ & $1.76 \mathrm{E}-05$ & $8-05$ \\
\hline $\mathrm{Nb}-94$ & $2.0 \mathrm{E}+4 \mathrm{y}$ & Beta & $3.63 \mathrm{E}-04$ & $3.63 \mathrm{E}-04$ & 3.63E-04 & $3.63 \mathrm{E}-04$ & $3.63 \mathrm{E}-04$ & E-04 & -04 \\
\hline $\mathrm{Nb}-95$ & $35 \mathrm{~d}$ & Beta/ $\gamma$ & $3.12 \mathrm{E}+01$ & $2.92 \mathrm{E}+01$ & $1.99 \mathrm{E}+01$ & $8.89 \mathrm{E}+00$ & $1.32 \mathrm{E}+00$ & $4.92 \mathrm{E}-04$ & E-16 \\
\hline $\mathrm{Nb}-95 \mathrm{~m}$ & $3.6 \mathrm{~d}$ & Beta & $2.17 \mathrm{E}-01$ & $1.70 \mathrm{E}-01$ & $8.87 \mathrm{E}-02$ & $3.35 \mathrm{E}-02$ & $4.50 \mathrm{E}-03$ & $1.64 \mathrm{E}-06$ & $2-18$ \\
\hline $\mathrm{Nb}-96$ & $23.4 \mathrm{~h}$ & Beta/y & $4.06 \mathrm{E}-04$ & $3.11 \mathrm{E}-11$ & $8.46 \mathrm{E}-30$ & $0.00 \mathrm{E}+00$ & $0.00 \mathrm{E}+00$ & $0.00 \mathrm{E}+00$ & $0.00 \mathrm{E}+00$ \\
\hline $\mathrm{Nb}-97$ & $1.23 \mathrm{~h}$ & Beta/y & $5.30 \mathrm{E}-02$ & $8.35 \mathrm{E}-12$ & $0.00 \mathrm{E}+00$ & $0.00 \mathrm{E}+00$ & $0.00 \mathrm{E}+00$ & $0.00 \mathrm{E}+00$ & $+\infty 0$ \\
\hline $\mathrm{Nb}-97 \mathrm{~m}$ & 588 & $\mathbf{T}$ & $4.99 \mathrm{E}-02$ & $7.34 \mathrm{E}-12$ & $0.00 \mathrm{E}+00$ & $0.00 \mathrm{E}+00$ & $0.00 \mathrm{E}+00$ & $0.00 \mathrm{E}+00$ & $0.00 \mathrm{E}+00$ \\
\hline $\mathrm{Mo}-93$ & $3.5 \mathrm{E}+3$ & ture & $6.93 \mathrm{E}-04$ & $6.93 \mathrm{E}-04$ & $6.93 \mathrm{E}-04$ & $6.93 \mathrm{E}-04$ & $6.93 \mathrm{E}-04$ & $6.92 \mathrm{E}-04$ & $\mathrm{E}-04$ \\
\hline Mo-99 & $2.75 d$ & Beta/ $\gamma$ & $6.16 \mathrm{E}+01$ & $1.87 \mathrm{E}-01$ & $5.05 \mathrm{E}-08$ & $7.10 \mathrm{E}-18$ & $6.66 \mathrm{E}-38$ & $0.00 \mathrm{E}+00$ & $0.00 \mathrm{E}+00$ \\
\hline Tc-99 & $2.1 \mathrm{E}+5 \mathrm{y}$ & Beta & $1.81 \mathrm{E}-04$ & $1.82 \mathrm{E}-04$ & $1.82 \mathrm{E}-04$ & $1.82 \mathrm{E}-04$ & $1.82 \mathrm{E}-04$ & $1.82 \mathrm{E}-04$ & $1.82 \mathrm{E}-04$ \\
\hline Ru-103 & $39.3 \mathrm{~d}$ & Beta & $1.37 \mathrm{E}-03$ & $9.13 \mathrm{E}-04$ & $3.17 \mathrm{E}-04$ & $6.47 \mathrm{E}-05$ & $2.46 \mathrm{E}-06$ & $6.21 \mathrm{E}-12$ & $1.59 \mathrm{E}-31$ \\
\hline In-113m & $1.66 \mathrm{~h}$ & Gamma & $7.10 \mathrm{E}-01$ & $6.18 \mathrm{E}-01$ & $4.31 \mathrm{E}-01$ & $2.50 \mathrm{E}-01$ & $8.21 \mathrm{E}-02$ & $1.01 \mathrm{E}-03$ & $2.08 \mathrm{E}-10$ \\
\hline In-114 & $49.5 \mathrm{~d}$ & Gamma & $5.06 \mathrm{E}-02$ & $3.67 \mathrm{E}-02$ & $1.58 \mathrm{E}-02$ & $4.49 \mathrm{E}-03$ & $3.36 \mathrm{E}-04$ & $1.22 \mathrm{E}-08$ & $3.47 \mathrm{E}-24$ \\
\hline In-114m & $1.84 \mathrm{~m}$ & $\beta+$ & $5.29 \mathrm{E}-02$ & $3.83 \mathrm{E}-02$ & $1.65 \mathrm{E}-02$ & $4.69 \mathrm{E}-03$ & $3.51 \mathrm{E}-04$ & $1.27 \mathrm{E}-08$ & 3.63E-24 \\
\hline
\end{tabular}


Table 2. Radionuclide Characteristics of CLWR TPBAR (Ci/TPBAR) (Cont'd)

\begin{tabular}{|c|c|c|c|c|c|c|c|c|c|}
\hline $\begin{array}{l}\text { Radio- } \\
\text { nuclide }\end{array}$ & Half-Life & $\begin{array}{l}\text { Decay } \\
\text { Mode }\end{array}$ & $\begin{array}{c}7 \\
\text { Days }\end{array}$ & $\begin{array}{c}30 \\
\text { Days }\end{array}$ & $\begin{array}{c}90 \\
\text { Days }\end{array}$ & $\begin{array}{c}180 \\
\text { Days }\end{array}$ & $\begin{array}{c}1 \\
\text { Year }\end{array}$ & $\begin{array}{c}3 \\
\text { Years } \\
\end{array}$ & $\begin{array}{c}10 \\
\text { Years } \\
\end{array}$ \\
\hline Sn-113 & $115.1 \mathrm{~d}$ & Gamma & $7.09 \mathrm{E}-01$ & $6.17 \mathrm{E}-01$ & $4.30 \mathrm{E}-01$ & $2.50 \mathrm{E}-01$ & $8.20 \mathrm{E}-02$ & $1.01 \mathrm{E}-03$ & 2.07E-10 \\
\hline $\mathrm{Sn}-117 \mathrm{~m}$ & $13.6 \mathrm{~d}$ & Gamma & $4.48 \mathrm{E}+00$ & $1.44 \mathrm{E}+00$ & $7.37 \mathrm{E}-02$ & \begin{tabular}{|c|}
$8.57 \mathrm{E}-04$ \\
\end{tabular} & $8.93 \mathrm{E}-08$ & $1.77 \mathrm{E}-23$ & $0.00 \mathrm{E}+00$ \\
\hline $\mathrm{Sn}-113$ & $115.1 \mathrm{~d}$ & Gamma & $7.09 \mathrm{E}-01$ & $6.17 \mathrm{E}-01$ & $4.30 \mathrm{E}-01$ & $2.50 \mathrm{E}-01$ & $8.20 \mathrm{E}-02$ & $1.01 \mathrm{E}-03$ & $2.07 \mathrm{E}-10$ \\
\hline $\mathrm{Sn}-117 \mathrm{~m}$ & $13.6 \mathrm{~d}$ & Gamma & $4.48 \mathrm{E}+00$ & $1.44 \mathrm{E}+00$ & $7.37 \mathrm{E}-02$ & $8.57 \mathrm{E}-04$ & $8.93 \mathrm{E}-08$ & $1.77 \mathrm{E}-23$ & $0.00 \mathrm{E}+00$ \\
\hline $\mathrm{Sn}-119 \mathrm{~m}$ & $293 \mathrm{~d}$ & Gamma & $4.79 \mathrm{E}+\infty 0$ & $4.49 \mathrm{E}+00$ & $3.79 \mathrm{E}+00$ & $2.94 \mathrm{E}+00$ & $1.74 \mathrm{E}+00$ & $2.20 \mathrm{E}-01$ & $1.59 \mathrm{E}-04$ \\
\hline $\mathrm{Sn}-121$ & $1.13 \mathrm{~d}$ & Beta & $4.27 \mathrm{E}-02$ & $2.69 \mathrm{E}-08$ & $1.80 \mathrm{E}-24$ & $0.00 \mathrm{E}+00$ & $0.00 \mathrm{E}+00$ & $0.00 \mathrm{E}+00$ & $0.00 \mathrm{E}+00$ \\
\hline $\mathrm{Sn}-121 \mathrm{~m}$ & $55 y$ & $\mathbf{I T}$ & $3.11 \mathrm{E}-04$ & $3.11 \mathrm{E}-04$ & $3.10 \mathrm{E}-04$ & $3.09 \mathrm{E}-04$ & $3.07 \mathrm{E}-04$ & $2.98 \mathrm{E}-04$ & $2.71 E-04$ \\
\hline $\mathrm{Sn}-123$ & $129.2 \mathrm{~d}$ & Beta & $2.71 \mathrm{E}-01$ & $2.39 \mathrm{E}-01$ & $1.74 \mathrm{E}-01$ & $1.07 \mathrm{E}-01$ & $3.96 \mathrm{E}-02$ & $7.86 \mathrm{E}-04$ & $8.64 \mathrm{E}-10$ \\
\hline Sn-125 & $9.63 d$ & Beta/y & $1.35 \mathrm{E}+\infty 0$ & $2.58 \mathrm{E}-01$ & $3.45 \mathrm{E}-03$ & 206 & $8 E-12$ & $0.00 \mathrm{E}+00$ & $0.00 \mathrm{E}+00$ \\
\hline$S b-122$ & $2.7 \mathrm{~d}$ & Beta & $5.14 \mathrm{E}-02$ & $1.40 \mathrm{E}-04$ & $2.87 \mathrm{E}-11$ & $2.66 \mathrm{E}-21$ & $0.00 \mathrm{E}+00$ & $0.00 \mathrm{E}+00$ & $0.00 \mathrm{E}+00$ \\
\hline Sb-124 & $60.2 d$ & Beta & $8.58 \mathrm{E}-03$ & 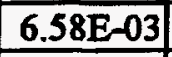 & $3.30 \mathrm{E}-03$ & $1.17 \mathrm{E}-03$ & $1.39 \mathrm{E}-04$ & $3.08 \mathrm{E}-08$ & $5.05 \mathrm{E}-21$ \\
\hline Sb-125 & $2.76 \mathrm{y}$ & Betaly & $1.05 \mathrm{E}+00$ & $1.04 \mathrm{E}+00$ & $1.00 \mathrm{E}+00$ & $9.41 \mathrm{E}-01$ & $8.29 \mathrm{E}-01$ & $5.03 \mathrm{E}-01$ & $8.72 \mathrm{E}-02$ \\
\hline Sb-126 & $12.4 \mathrm{~d}$ & Beta & $2.59 \mathrm{E}-02$ & $7.16 \mathrm{E}-03$ & $2.50 \mathrm{E}-04$ & $1.63 \mathrm{E}-06$ & $5.17 \mathrm{E}-11$ & $9.41 \mathrm{E}-29$ & $0.00 \mathrm{E}+00$ \\
\hline $\mathrm{Te}-123 \mathrm{~m}$ & $119.7 \mathrm{~d}$ & $\mathbf{I T}$ & $1.06 \mathrm{E}-03$ & $9.28 \mathrm{E}-04$ & $6.56 \mathrm{E}-04$ & $3.89 \mathrm{E}-04$ & $1.33 \mathrm{E}-04$ & $1.94 \mathrm{E}-06$ & $7.17 E-13$ \\
\hline $\mathrm{Te}-125 \mathrm{~m}$ & $58 \mathrm{~d}$ & Gamma & $2.07 \mathrm{E}-01$ & $2.15 \mathrm{E}-01$ & $2.25 \mathrm{E}-01$ & $2.23 \mathrm{E}-01$ & $2.02 \mathrm{E}-01$ & -01 & $2.13 \mathrm{E}-02$ \\
\hline \multicolumn{2}{|c|}{$\begin{array}{l}\text { Total photons/s/ } \\
\text { TPBAR }\end{array}$} & & $1.50 \mathrm{E}+13$ & $1.05 \mathrm{E}+13$ & $6.72 \mathrm{E}+12$ & $4.44 E+12$ & $2.99 \mathrm{E}+12$ & $1.92 \mathrm{E}+12$ & $7.63 E+11$ \\
\hline \multicolumn{2}{|l|}{$\mathrm{MeV} / \mathrm{s}$} & & $8.90 E+12$ & $7.44 E+12$ & $5.56 \mathrm{E}+12$ & $4.12 \mathrm{E}+12$ & $3.06 \mathrm{E}+12$ & $2.08 \mathrm{E}+12$ & $8.05 \mathrm{E}+11$ \\
\hline \multicolumn{2}{|c|}{$\begin{array}{l}\text { Decay Heat, } \\
\text { watts/TPBAR }\end{array}$} & & 219 & 1.70 & 1.34 & 1.08 & 0.88 & 0.68 & 0.3 \\
\hline \multicolumn{2}{|c|}{$\begin{array}{l}\text { Decay Heat, } \\
\text { watts/charge* }\end{array}$} & & 6 & 10 & 402 & 324 & 264 & 204 & 100 \\
\hline
\end{tabular}

*Assume 300 rods (full-length basis) in each furnace charge/basket

IT $=$ Isomeric transition 


\subsubsection{Tritium}

Tritium is a radioactive isotope of hydrogen with a half life of 12.3 years. It has a specific activity of about $9,600 \mathrm{Ci} / \mathrm{gm}$. It is a pure beta emitter with a maximum energy of $18.6 \mathrm{keV}$ and an average energy of $5.6 \mathrm{keV}$. Tritium produces a decay heat of about 0.324 watts $/ \mathrm{gm}$. It decays by emitting an electron to form He-3. Tritium will be the primary radioactive contaminant in CLWRTEF post-extraction low-level waste streams.

Tritium will permeate or diffuse into almost all surfaces with which it comes into contact and will readily exchange with hydrogen-containing materials such as moisture, corrosion oxide products, oils and polymeric materials. Thus all systems that come into contact with primary tritium confinement systems (pipe, tank, etc.), such as liquid and gas coolants/heat transfer media, will eventually become contaminated with tritium.

Tritium contamination may be in the form of "fixed" or "removable" contamination. Fixed contamination (not removable by wiping) is in the form of a physical matrix into which tritium has diffused or dissolved, such as in a tank, piping or metal hydride bed. This means that tritium has actually diffused into the matrix of the container or metal components (metal films, piping, pump housings, etc.). Elemental tritium diffused into any material will diffuse back out when the original tritium source is removed. Fixed contamination such as metal tritide is very stable and can only be removed or desorbed by heating (for example, to about $650^{\circ} \mathrm{C}$ for titanium tritide) or isotopic exchange with protium or moisture. Removable or smearable contamination is generally in the form of an oxide, or tritiated water (HTO), or tritiated organic (oil, grease, etc.). Tritium oxide in tritium-processing equipment is unavoidable and will form any time tritium is exposed to air or moisture. It is formed by oxidation, or, more commonly, by isotopic exchange with elemental hydrogen in moisture.

In the CLWR-TEF, spent TPBARs will contain residual fixed tritium contamination that was not extracted in the furnace. Some tritium will diffuse out of the TPBARs with time, with most tritium expected to be lost to decay. Most job control waste in the tritium processing and purification operations will contain removable tritium contamination. Failed tritium process equipment and maintenance parts will contain primarily fixed contamination.

\subsection{Waste Treatment and Disposal}

\subsubsection{Waste Treatment}

Treatment and disposal options for CLWR-TEF wastes are summarized in Table 3. Waste streams in each treatment/disposal category are listed in Appendix F. While compaction only is a viable treatment for low-level waste, most RCRA wastes require some sort of stabilization of the final waste form. Wastes that may be either compacted or thermally destroyed include water treatment filters and the job control waste streams. Waste irradiated TPBAR assemblies may be cut to achieve volume reduction for disposal. The possibility of tritium-contaminated metal recycling should also be investigated by Operations after start-up of the facility, given that SRS is working with commercial vendors to recycle tritium-contaminated stainless steel from reactor heat exchangers by using it to make waste containers. Examples of wastes that require 
encapsulation are those that contain RCRA-listed heavy metals, such as lead and RCRA-metal shielding material. Much of the tritium-contaminated liquid wastes, such as glovebox bubbler fluids and nonhazardous tritiated oil, may be incinerated. For the remainder, and because of their small expected total volume, it is recommended to stabilize them in absorbent materials for EArea Vault disposal.

Table 3. Treatment/Disposal Options for CLWR-TEF Waste

\begin{tabular}{|c|c|c|c|c|}
\hline $\begin{array}{c}\text { Treatment/Disposal } \\
\text { Option }\end{array}$ & Waste Type & $\begin{array}{l}\text { Mass } \\
\text { kg/yr }\end{array}$ & $\begin{array}{l}\text { Volume } \\
\mathbf{m}^{3} / \mathbf{y r}\end{array}$ & $\begin{array}{c}\text { Avg } \\
\text { Waste } \\
\text { Density } \\
\text { kg/m } \mathbf{m}^{3}\end{array}$ \\
\hline $\begin{array}{l}\text { CIF Incineration followed by } \\
\text { Stabilization of residue }\end{array}$ & $\begin{array}{l}\text { Low-Level } \\
\text { Mixed } \\
\text { Tritiated Oil }\end{array}$ & $\begin{array}{r}30,950 \\
380 \\
198 \\
\end{array}$ & $\begin{array}{r}230 \\
2.5 \\
0.22 \\
\end{array}$ & $\begin{array}{l}134 \\
152 \\
900 \\
\end{array}$ \\
\hline $\begin{array}{l}\text { Compaction for LAW Vault } \\
\text { disposal }\end{array}$ & Low-Level & 10,000 & 75 & 134 \\
\hline Direct LAW Vault Disposal & Low-Level & 17,220 & 80 & 215 \\
\hline Direct ILTV Silo Disposal & \begin{tabular}{|l|} 
Intermediate- \\
Level \\
\end{tabular} & 18,270 & 19 & 962 \\
\hline Direct IITV Bulk Cell Disposal & $\begin{array}{l}\text { Intermediate- } \\
\text { Level } \\
\end{array}$ & 13,900 & 16 & 870 \\
\hline $\begin{array}{l}\text { Package for storage and/or off- } \\
\text { site disposal }\end{array}$ & \begin{tabular}{|l|} 
Mixed \\
Hazardous \\
\end{tabular} & $\begin{array}{r}410 \\
4.5 \\
\end{array}$ & $\begin{array}{r}2.5 \\
0.004 \\
\end{array}$ & $\begin{array}{r}164 \\
1,125 \\
\end{array}$ \\
\hline Other* & $\begin{array}{l}\text { Low-Level } \\
\text { Mixed } \\
\text { Hazardous }\end{array}$ & $\begin{array}{r}- \\
- \\
1250\end{array}$ & $\begin{array}{r}- \\
1.3\end{array}$ & $\begin{array}{r}- \\
960\end{array}$ \\
\hline
\end{tabular}

*Includes the following waste streams: Analytical Laboratory/Rad Con chemicals, HEPA filters, gold traps, ion exchange resins, palladium membranes, etc. These are wastes for which treatment/disposal cannot a priort be defined. They are expected to constitute $<1 \%$ by volume and weight of CLWR-TEF wastes. A significant portion of Analytical Lab/Rad Con chemicals are expected to be recycled or be consumed as scintillation counting cocktails and be discharged to laboratory drains to the ETF. Treatment of analytical chemicals will be a function of the type of chemical; e.g., solid, liquid, acid, base, etc. Treatment of HEPA filters will also be a function of their composition; i.e., whether they are largely paper (thermal treatment) or metal (compaction).

PPE job control wastes would be most effectively treated using incineration followed by stabilization of the ash residue. Incineration combined with stabilization would reduce the waste volume by roughly a factor of 10 . If thermal treatment such as incineration is not used for PPE wastes, the majority of CLWR-TEF wastes would receive only the most basic treatment (compaction) prior to disposal. This would achieve a volume reduction of 4-6. In addition to providing greater volume reduction, at least one study has shown incineration to be more economical. A recent comparison of waste compaction with off-site treatment and disposal versus on-site incineration conducted by SRS for the Consolidated Incineration Facility concluded 
that annual operating costs would be \$20.3M for compaction and \$13.5M for incineration (Ref. 21).

This PWA assumes that CLWR-TEF waste streams will be treated and disposed of at SRS as much as possible and as economically as possible. Existing and planned treatment facilities for SRS are discussed in Appendix C.

\subsubsection{Waste Disposal}

DOE Order 5820.2A requires that all DOE low-level waste be disposed of at a DOE disposal facility. CLWR-TEF low-level waste is assumed to be disposed of at SRS in the E-Area Vaults or in a future LLW disposal facility. Other DOE sites capable of receiving CLWR-TEF low-level wastes are the Nevada Test Site (NTS) and Hanford. NTS is a disposal site for low-level waste (see Section C3.2), but has no treatment capabilities, and none are planned. The Hanford Site is similar to SRS and possesses both treatment and disposal capabilities. A formal application and approval process must be completed before waste can be shipped to either of these two sites. No DOE facility is currently authorized to accept off-site mixed low-level waste (MLLW) for disposal; however, Hanford has accepted some shipments for storage on a case-by-case basis. Hanford, LANL, NTS, and SRS all have planned MLLW disposal facilities that are in the conceptual design phase and the preliminary stages of RCRA Part B permit applications. DOE currently allows mixed waste to be shipped to one permitted commercial facility, Envirocare of Utah, Inc., on a case-by-case basis. Other commercial waste disposal facilities capable of receiving and treating low-level and mixed low-level waste are DSSI and SEG in Tennessee. CLWR-TEF hazardous waste, per current SRS practice, could be disposed of at any DOEapproved commercial facility that would accept it.

\subsection{PWA Critical Assumptions}

The waste streams in this PWA are estimated based on the following critical assumptions, derived partially from Ref. 22-23. If these assumptions are changed materially, then the results presented here would need to be updated.

- TEF staffing is 108 persons; consisting of $\mathbf{4 8}$ shift workers and 60 day workers; with a maximum daytime staffing of 72 persons.

- TEF operates 24 hours a day, 7 days a week, 365 days a year.

- Current SRS tritium waste generation rates provide valid baselines for projecting CLWR-TEF waste generation rates.

- Radioactive waste generation rates are proportional to production activity (i.e., the number of extractions).

- Waste minimization initiatives will reduce job control waste for comparable activities by $50 \%$ by the time of CLWR-TEF start-up. 
- Solid and liquid sanitary sewerage generation rates are proportional to facility staffing level.

- Personal protection equipment to be used in the CLWR-TEF will be incinerable. They will need to be manufactured out of non-polyvinyl chloride (PVC) materials in the future or be PVC materials currently being used on site. New PVC or banned PVC materials may not be reintroduced to the waste stream and change the SRS site loading of PVC. (Current tritium plastic suits, Tygon tubes and Pylox gloves in use all contain PVC.)

- The administrative control weight limit on a 21" 21 " $\times 21$ " cardboard box waste container is $50 \mathrm{lb}$.

- For waste forecasting, most tritium processing equipment will be assumed to be constructed of stainless steel.

- CLWR production capacity is 4,200 TPBARs per year.

- TPBARs are shipped to SRS in shipping/storage containers placed inside shielded transportation casks.

- TPBARs are to be extracted in extraction baskets and extracted spent TPBARs and extraction basket will be disposed of together.

- Each extraction TPBAR basket holds 300 full-length TPBARs.

- 14 baskets of TPBARs will be extracted in vacuum furnaces each year.

- Furnaces are assumed to last the life of CLWR-TEF, although heaters and covers are assumed to require periodic replacement. The capability exits to remove and replace a failed furnace.

- Spent TPBAR characterization is currently based on ORIGEN2 code calculations made by PNNL. Analytical data to be obtained from planned irradiation of Lead Test Assemblies will be used to verify code calculations.

- Waste Treatment Volume Reduction Factors are assumed as follows:

$\begin{array}{ll}\text { Compaction } & 4 \\ \text { Supercompaction } & 6 \\ \text { Incineration } & 20 \\ \text { Stabilization } & 1 / 2 \text { (volume doubles) }\end{array}$


- Cask decontamination/cleaning is assumed to occur at the CLWR-TEF, rather than at other potential locations such as the Receiving Basin for Off-site Fuel (RBOF).

- TPBARs will not be routinely analyzed by liquid chemistry before and after each extraction.

- Photographic waste will be minimized by using digital imaging. If conventional silver-based radiographs are taken in tritium-contaminated environments, they will be decontaminated for disposal as clean waste.

\subsection{Challenging Waste Streams and Waste Management Issues}

The CLWR-TEF will generate several challenging waste streams which are only partially addressed in the PWA. Definitive resolution will require collection of additional data or development of new process technologies. These are described below.

\subsubsection{Spent TPBAR/Crud Characterization}

Spent TPBAR and crud characterization data are limited and preliminary. Once a commercial utility reactor is selected, the irradiation of a test batch will provide definitive data for benchmarking code calculations and crud analysis.

\subsubsection{Tritiated Liquid Waste}

A number of liquid streams will be contaminated with tritium and may not be disposed of easily: tritiated oil, glovebox bubbler fluid and tritium-contaminated water. Much of this waste may be incinerated at the CIF if the Waste Acceptance Criteria can be met. Tritiated oil and glovebox bubbler fluid, due to their small anticipated volumes may be disposed as solid waste by stabilizing in an absorbent material and overpacked. This treatment and disposal method will take advantage of institutional control and the tritium decay half-life of 12.3 years, which will reduce tritium by about $99.6 \%$ in 100 years. However, this treatment and disposal method has not been used recently at SRS and an exemption to the EAV WAC may be required. Other strategies for addressing these wastes include reducing the concentration of tritium in contaminated cooling water by using once-through cooling and in bubbler fluid by more frequent change-out. Operational flexibility in dealing with these waste streams is increased. However, the waste volumes will increase as a trade-off.

\subsubsection{Tritium Permeation and Quantification}

It is not possible to quantitatively determine the tritium content in the bulk of a waste component based strictly on detected tritium off-gassing rates. Tritium will permeate or diffuse into almost all surfaces that it contacts and will readily exchange with hydrogen-containing materials such as moisture, corrosion oxide products, oils and polymeric materials. The current SRS Tritium Facilities waste characterization plan assigns nominal amounts of tritium to tritium-contaminated piping, flanges, and other miscellaneous standard equipment parts. This tritium will include both analytically determined tritium trapped in corrosion product oxide layers and tritium calculated to permeate into the metal matrix. It is important to use a proper degree of benchmarking for the CLWR-TEF waste. Attaching a "nominal" value to each "type" of waste component, rather than analyzing each individually in detail, is cost-effective, but may be non-conservative. This 
methodology and use of nominal or average values is satisfactory for Curie brokering (tracking and management of radionuclide Curies from waste packages) to meet radionuclide limits and optimize capacity utilization in the E-Area Vaults. From an operational viewpoint, one should be prepared for a tritium "puff" release if such tritiated waste is compacted, due to the off-gassing of tritium into the waste bag from components containing potentially much higher than "nominal" amounts of tritium.

\subsubsection{Waste Classification/Greater-Than-Class C}

There are several waste classification issues. First, the highly radioactive spent TPBAR waste, which will be remote-handled, is classified as low-level waste under current DOE guidelines. This low-level waste classification or designation (also referred to at SRS as Intermediate Level Waste to distinguish it from contact-handled low-level waste) may be challenged and need to be defended by DOE.

Secondly, a number of CLWR-TEF waste streams are potentially characteristic mixed waste streams. For example, waste streams which include incoloy, zircaloy and stainless steel contain chromium, a RCRA metal. But due to their well-established corrosion resistance, chromium is not considered leachable and these wastes are not considered to be mixed waste in this PWA. In addition, nickel, which is present in the TPBAR, may become a RCRA metal in the future. Thus, although the spent TPBAR and spent TPBAR-contaminated wastes are not classified as mixed waste in this PWA, there are qualifications associated with that determination at this time.

Lastly, the spent TPBAR waste has a potential for exceeding the Greater-Than-Class C classification for radioactive waste regulated by the Nuclear Regulatory Commission (NRC). Under NRC regulations (10CFR61), greater-than-class $C$ wastes are not considered generally acceptable for near-surface disposal and thus may not be shipped to an NRC-regulated commercial site for disposal without a special petition and approval. Limits for Class C components such as $\mathrm{C}-14, \mathrm{Ni}-59$, and $\mathrm{Nb}-94$ are listed in Table 4, which is reproduced from 10CFR61.55 Table 1 and Table 2. CLWR-TEF is not expected to produce the last three listed radionuclides: TRU nuclides with greater than 5 year half lives, $\mathrm{Pu}-241$ and $\mathrm{Cm}-242$. Ni and Nb isotopes are the only Table 4 radionuclides currently expected to be present in the spent TPBAR and crud waste. The remaining isotopes are not known with certainty. If the waste contains more than one of the listed radionuclides, a sum of fractions calculation is required to determine Greater-Than-Class-C classification. 
Table 4

NRC Greater-Than-Class C Radionuclide Limits

\begin{tabular}{|l|c|}
\hline \multicolumn{1}{|c|}{ Radionuclide } & Class-C Limit, Ci/m3 \\
\hline C-14 & 8 \\
\hline C-14 in activated metal & 80 \\
\hline Ni-59 in activated metal & 220 \\
\hline Ni-63 & 700 \\
\hline Ni-63 in activated metal & 7,000 \\
\hline Sr-90 & 7,000 \\
\hline Nb-94 in activated metal & 0.2 \\
\hline Tc-99 & 3 \\
\hline I-129 & 0.06 \\
\hline Cs-137 & 4,600 \\
\hline $\begin{array}{l}\text { Alpha-emitting transuranic } \\
\text { nuclides with >5-yr half lives }\end{array}$ & $* 100$ \\
\hline Pu-241 & $* 3,500$ \\
\hline Cm-242 & $* 20,000$ \\
\hline
\end{tabular}

*Units are in nanocuries per gram ( $\mathrm{nCi} / \mathrm{gm})$ for transuranics.

\subsubsection{CLWR-TEF Process Technology Uncertainties} CLWR-TEF waste streams will be process-specific. They will depend on what technologies, equipment and materials are adopted for the production process. For example, current RTF tritium confinement systems use catalyst and zeolite beds in stripper cleanup systems. (See Appendix A for a description of these processes). Z-bed regeneration and tritium recovery from the desorbed tritiated water may be achieved using either $\mathrm{Mg}$ beds or $\mathrm{U}$ beds (per existing 232-H Tritium Extraction Facility and 233-H Replacement Tritium Facility). The current CLWR-TEF baseline technology is to use $\mathrm{Mg}$ beds. In either case, the $\mathrm{Mg}$ or $\mathrm{U}$ beds become spent and have to be replaced, resulting in waste $\mathrm{Mg}$ or $\mathrm{U}$ beds.

\subsection{Waste Minimization Technologies and Process Development}

A number of opportunities in the CLWR-TEF processes for waste minimization were incorporated into the facility conceptual design. Several opportunities from promising new technologies under development were evaluated but not adopted for the conceptual design at this time. Two of these waste minimization technology and process development opportunities are 
being supported by the Accelerator Production of Tritium Project: palladium membrane reactor and solid oxide electrolysis. Successful development of these technologies may expedite their implementation in the existing Tritium Facilities or the CLWR-TEF for recovering tritium from zeolite beds. Either process will eliminate the need to dispose of spent magnesium or uranium beds used in $Z$ bed recovery. These technologies are discussed below.

\subsubsection{Palladium Membrane Reactor}

The palladium membrane reactor (PMR) can be used for the recovery of hydrogen isotopes from compounds such as water and methane. In a heated catalytic reactor, water is reacted with carbon monoxide to produce elemental hydrogen:

$$
\mathrm{H}_{2} \mathrm{O}+\mathrm{CO}=\mathrm{H}_{2}+\mathrm{CO}_{2}
$$

The hydrogen gas is removed using a palladium membrane, as in the $\mathrm{Pd}-\mathrm{Ag}$ diffuser. More than one reactor stage may be needed for complete processing of water. The PMR technology has been under development at LANL for a number of years. It is also under consideration for use in the APT Tritium Separation Facility. Although much data have been obtained to support equipment sizing and design, a plant-configured prototype needs to be demonstrated with a dilute tritium mixture to obtain reliability data and determine the long-term effects of introducing $\mathrm{CO}$, $\mathrm{CO}_{2}$ and other organic by-products.

\subsubsection{Solid Oxide Electrolysis}

In Solid Oxide Electrolysis, high temperature, gas-phase water vapor is cracked by passage of a current through a solid electrolytic cell. The steam is decomposed into hydrogen and hydroxyl ions which are separated by a ceramic membrane. Hydrogen and tritium ions combine to form elemental hydrogen and tritium gases, which are returned to the primary process. Hydroxyl ions combine to form water and oxygen. Solid Oxide Electrolysis is particularly attractive because the oxygen stream produced is dry and clean, with very low tritium content, which may allow it to be discharged to the stack with minimal treatment. This technology would reduce the number of line breaks, handling of uranium/magnesium bed waste, and the potential for personnel exposure.

\section{Conclusions}

Several potential CLWR-TEF hazardous and mixed low-level waste streams have been identified in this PWA and should be greatly mitigated, if not avoided altogether. Almost all low-level radioactive waste streams from CLWR-TEF tritium processing operations are expected to meet the current Waste Acceptance Criteria for disposal in the E-Area Vaults or the Consolidated Incineration Facility. Crud-contaminated, non-TPBAR waste should also meet the WAC. However, based on currently available irradiated TPBAR characterization data from PNNL, it appears that disposal of 300 spent TPBARs in each EAV ILTV silo would exceed the ILV WAC limits for several of the radionuclides (C-14, Ni-59, Tc-99), if the TPBARs are processed and disposed of within one year. The current Interim WAC3.17 for ILTV silos only have radionuclide limits for $\mathrm{H}-3$ and $\mathrm{CO}-60$ and not the other radionuclides. The author believes this will be corrected and should be similar to the IIV radionuclide limits. A petition for disposal of the 
irradiated baseplates and spent TPBAR waste streams should be submitted to the Solid Waste Management Division at SRS to initiate a new waste review. Definitive ILTV silo WAC radionuclide limits will then be determined based on a waste performance assessment to determine the disposability of the irradiated baseplates and spent TPBARs in the silos. Assuming irradiated baseplates and spent TPBARs may be accepted for disposal, the capacity of the existing IITV silos is estimated to be adequate for about 3-5 years of CLWR-TEF operation. 


\section{REFERENCES}

1. DOE, "Commercial Light Water Reactor Project Execution Plan," CLWR-PLN-9010-01, Draft 2, June 1996.

2. WSRC, "Pre-Conceptual Design Package for the Commercial Light Water Reactor Tritium Extraction Facility," M-CDP-H-00017, June 28, 1996.

3. WSRC, "Facility Design Description for Commercial Light Water Reactor Tritium Extraction Facility," G-FDD-H-00006, Rev. 2, September 22, 1997

4. WSRC, "Conceptual Design Report - Commercial Light Water Reactor (CLWR) Tritium Extraction Facility (U)," 98-D-125, July 8, 1997.

5. BNL, "Topical Report on Revision-1 of a Pre-Conceptual Design for the SpallationInduced Lithium Conversion (SILC) Target for the Accelerator Production of Tritium (APT)", ATD/APT (Rev. 0), June 10, 1994.

6. SNL, "Accelerator Production of Tritium Project Process Waste Assessment," SAND942217, UC-721, September 1995.

7. SNL, "Accelerator Production of Tritium Programmatic Environmental Impact Statement Input Submittal," SAND93-2094, November 1, 1993.

8. APT Programmatic Environmental Impact Statement Input Submittal, Rev. 1, May 10 1993.

9. Wilson, Brad, "Tritium Facilities CY95 Waste Minimization Plan," NMP-STE-95-0035, April 24, 1995.

10. WSRC, "Defense Program Division Low Level/Mixed Waste Certification Plan," WSRCIM-95-26, Rev. 1, December 14, 1995.

11a. WSRC, "System Design Description for Solid Waste Management Systems," Q-SYD-H00001, Rev. C, 9/16/96.

11b. WSRC, "System Design Description for Radiation and Contamination Sampling/ Monitoring Systems," Q-SYD-H-00002, Rev. A, 9/96.

11c. WSRC, "System Design Description for Process Confinement and Clean-up," Q-SYD-H00003, Rev. C, 9/16/96. 
11d. WSRC, "System Design Description for Receiving, Handling and Storage Systems," GSYD-H-00102, Rev. A, 9/96.

11e. WSRC, "System Design Description for Tritium Extraction Systems," X-SYD-H-00001, Rev. 0, 9/26/96.

11f. WSRC, "System Design Description for Inert Separation System," X-SYD-H-00002, Rev. 0, 9/23/96.

11g. WSRC, "System Design Description for Hydrogen Isotope Separation System," X-SYDH-00003, Rev. 0, 9/23/96.

11h. WSRC, "System Design Description for Tritium/Product Delivery System," X-SYD-H00004, Rev. 0, 9/23/96.

11i. WSRC, "System Design Description for Product and Flush Gas Evacuation System," XSYD-H-00005, Rev. 0, 9/23/96.

11j. WSRC, "System Design Description for Tritium Recovery Systems," X-SYD-H-00006, Rev. 0, 9/23/96.

11k. WSRC, "System Design Description for Tritium Processing Support Systems," X-SYDH-00007, Rev. 0, 9/23/96.

111. WSRC, "System Design Description for HP and Radiometric Laboratory System," XSYD-H-00008, Rev. A, 9/96.

11m. WSRC, "System Design Description for Mass Spectrometry and Accountability Measurement Systems," X-SYD-H-00009, Rev. A, 9/96.

11n. WSRC, "System Design Description for Material and Characterization Laboratory System," X-SYD-H-00010, Rev. A, 9/96.

110. WSRC, "System Design Description for Process Heating and Cooling System," X-SYDH-00011, Rev. 0, 9/23/96.

11p. WSRC, "System Design Description for Electrical Power Supply Systems," E-SYD-H00013, Rev. A, 9/96.

11q. WSRC, "System Design Description for Storm Sewer System" C-SYD-H-00001, Rev. A, 9/16/96.

11r. WSRC, "System Design Description for Domestic Water Supply System," M-SYD-H00003, Rev. A, 9/96. 
11s. WSRC, "System Design Description for Sanitary Waste Water System," Q-SYD-H00004, Rev. A, 9/96.

11t. WSRC, "System Design Description for Process Waste Water System," Q-SYD-H-00005, Rev. A, 9/96.

11u. WSRC, "System Design Description for Process and Building Chilled Water Systems," MSYD-H-00004, Rev. A, 9/96.

11v. WSRC, "System Design Description for Inert Gas Systems," M-SYD-H-00005, Rev. A, 9/96.

11w. WSRC, "System Design Description for Plant, Instrument and Breathing Air Systems," M-SYD-H-00006, Rev. A, 9/96.

11x. WSRC, "System Design Description for HVAC System," M-SYD-H-00007, Rev. A, 9/11/96.

11y. WSRC, "System Design Description for Process Heating and Cooling System," X-SYDH-00011, Rev. C, 9/96.

11z. WSRC, "System Design Description for Integrated Control System," J-SYD-H-00003, Draft C, 9/16/96.

11aa. WSRC, "System Design Description for Plant Communication System," G-SYD-H00103, Rev. C, 9/96.

11bb. WSRC, "System Design Description for Safeguards and Security System," S-SYD-H00001 , Rev. C, $9 / 96$.

11cc. WSRC, "System Design Description for Fire Protection System," F-SYD-H-00001, Rev. C, $9 / 96$.

11dd. WSRC, "System Design Description for TEF Building and Cell Structures," C-SYD-H00002, Rev. C, 9/96.

11ee. WSRC, "System Design Description for TEF Support Facilities," C-SYD-H-00003, Rev. C, $9 / 96$.

11ff. WSRC, "System Design Description for TEF Roads and Rail Spurs," C-SYD-H-00004, Rev. C, $9 /$ YY/96.

12. SNL conversation with Luke Bartlein of the TSTA facility, April 26, 1994 
13. LANL, "Tritium Systems Test Assembly Final Safety Analysis Report."

14. L. K. Heung et al, "Tritium Confinement in a New Tritium Processing Facility at the Savannah River Site", Fusion Technology, Vol 21, March 1992

15. Theodore Motyka, "The Replacement Tritium Facility", Fusion Technology, Vol 21, March 1992.

16. M. S. Ortman, et al, "Tritium Processing at the Savannah River Site: Present and Future", J. Vac. Sci. Technol., A 8 (3), May/Jun 1990.

17. WSRC, "Savannah River Site Waste Acceptance Criteria Manual," WSRC 1S Manual.

18. Brizes, W.F., “TPBAR Source Term (U)," DPD-TEF-97-0015, April 3, 1997.

19. PNL, "Characteristics of Fuel Crud and Its Impact on Storage, Handling and shipment of Spent Fuel," PNL-6273, UC-85, September 1987.

20. WSRC, E-Mail Message, "CLWR-TEF Action Item on Crud," W.R. Mangiante to G. E. Abell, September 5, 1996.

21. H. L. Pope, C. McVay and T. Holm-Hansen, "A 'Fresh Look' at a U. S. Department of Energy Mixed Waste Incinerator," 1994 International Incineration Conference, Houston, TX, May 9-12, 1994

22. WSRC, "CLWR-TEF Conceptual Phase Key Assumptions," Rev. August 5, 1996

23. WSRC, E-Mail Message, A. O. Delley to J. R. Puruker, "Overpack and Transport Cask Design," August 1, 1996.

24. PNNL, Letter, G. J. Sevigny to W. F. Brizes, " Responses to 'Information Needs to Support the Tritium Extraction Facility', "September 25, 1997. 


\section{APPENDIX A \\ Commercial Light Water Reactor-Tritium Extraction Facility Processes and Operations}

Assemblies of tritium producing burnable absorber rods (TPBARs) are irradiated in a Commercial Utility Light Water (nuclear) Reactor (CLWR) to produce tritium. The irradiated TPBARs are removed and shipped to SRS. At SRS, the Commercial Light Water Reactor-Tritium Extraction Facility (CLWR-TEF) extracts the tritium from the irradiated TPBARs and purifies it through a number of chemical and physical separation steps. Operation of the CLWR-TEF generates waste streams of materials that cannot be recycled or reused, including system components which fail through usage or exposure to harsh environments, or which must be replaced due to aging, degradation and obsolescence. Other waste streams are generated in decontamination and maintenance operations, which produce significant volumes of job control waste consisting of kraft paper, plastic sheets, shoe covers, gloves, plastic suits, and solvent wipes.

There are two points to keep in mind with respect to waste generation and management. First, since tritium is the only product of the CLWR-TEF, all other process materials introduced into the facility will potentially end up as waste, either during its operational life or when it is to be decontaminated and decommissioned. Thus, the simpler the CLWR-TEF processes and the fewer operations conducted, the smaller will be the waste generation. The second important point is that treatment and disposal options are dependent upon the characteristics of the waste. CLWRTEF will introduce three sources of radioactive contamination: the irradiated TPBARs, the "crud" coating on irradiated TPBARs, and tritium, once it is extracted or separated from the TPBARs (See Section 5.2 of the main text).

As CLWR-TEF operations and processes are discussed in this appendix, process outputs and system components that result in waste streams are identified. The proposed processes and conceptualized operations for the CLWR-TEF are organized into the following sections:

A1. Cask/TPBAR Receiving, Decontamination, Handling and Storage

A1.1 Cask/TPBAR Receipt

A1.2 TPBAR Storage

A1.3 Cask/Trailer Decontamination

A1.4 TPBAR/Cask Handling

A2. Tritium Extraction

A2.1 TPBAR Prep

A2.2 Furnace Extraction

A3. Tritium Processing

A3.1 Conversion of Hydrogen Isotopes to Elemental Form

A3.2 Removal of Impurity Gases

A3.3 Removal of Tritium from Stack Gas

A4. Tritium Process Confinement and Clean-up Systems 
A4.1 Confinement Systems

A4.2 Tritium Clean-up and Recovery Systems

A4.3 Confinement Monitoring Systems

A5. Tritium Analysis and Accountability

A5.1 HP and Radiometric Lab

A5.2 Mass Spectrometry and Accountability

A5.3 Material Characterization Lab

A5.4 Low-level Waste Assay

A6. Balance of Plant Facilities

A6.1 Electrical Power

A6.2 Steam

A6.3 Domestic Water Supply

A6.4 Sanitary Wastewater

A6.5 Process and Building Chilled Water

A6.6 Process Wastewater

A6.7 Storm Sewer System

A6.8 Fire Protection

A6.9 Inert Gas Systems

A6.10 Plant, Instrument and Breathing Air

A6.11 Building HVAC

A6.12 Process Heating/Cooling

A6.13 Control Room/Integrated Control System

A6.14 Offices and Change Rooms

A6.15 Safeguards and Security

A6.16 Emergency Services

A6.17 Tritium Equipment Decon Facility

A6.18 Communication Services

A6.19 Maintenance Facilities

A6.20 Balance of Plant Waste Streams

A simplified schematic of the CLWR-TEF processes is shown in Figure Al. 


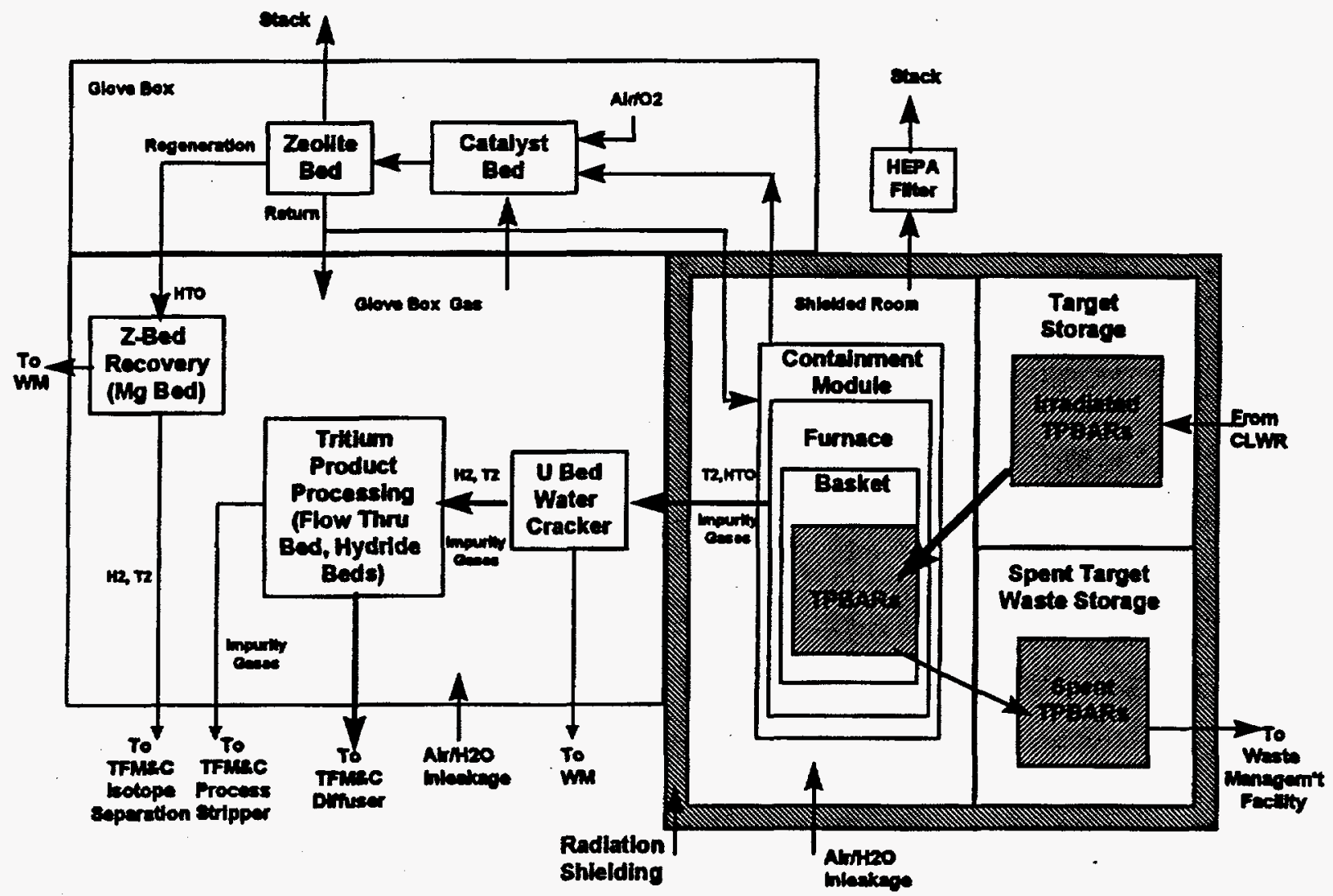

Fig. A-1 CLWR-TEF Process Schematic 


\section{A.1 Cask/TPBAR Receiving, Decontamination, Handling and Storage}

The Commercial Light Water Reactor-Tritium Extraction Facility must provide for the receipt, unloading, inspection, and storage of irradiated TPBAR assemblies. The TPBAR/cask handling equipment will also be used to load packaged spent TPBARs onto transport equipment for removal to the waste storage or disposal site. Due to the weight and high gamma activity expected, many operations will be performed remotely in shielded areas. TPBAR shipping casks to be returned to the CLWR Utility must also be decontaminated, as needed.

\section{A1.1 Cask/TPBAR Receipt}

Containerized irradiated TPBARs from the CLWR are received at the CLWR-TEF inside shielded transport casks to meet Department of Transportation and Nuclear Regulatory Agency guidelines. The Commercial Utility is assumed to have already separated the baseplates from the TPBAR assemblies, inspected the TPBARs for failures and consolidated the irradiated TPBARs into baskets of 300 TPBARs (nominal) each. This PWA will assume that the baseplates will be shipped to SRS for disposal. Failed TPBARs will be shipped to SRS for evaluation, waste characterization and disposal. The shipping/storage container is assumed to be compatible for the extraction process and becomes the extraction basket. The basket of TPBARs will have been completely dried and inerted with $\mathrm{He}-4$ and provided with a non-air tight lid.

On receipt at SRS, the casks are uprighted using a crane, the TEF building hatch is opened and the casks are moved into the decontamination area. The casks are "sniffed' using a local tritium monitor to determine cask and TPBAR cladding integrity. Exteriors are smeared for contamination. Prior to removing the baskets of TPBARs or TPBAR assemblies from the shipping cask, it may also be necessary to evacuate the cask volume and purge with an blanketing dry gas such as nitrogen to remove residual water and off-gassed tritium. In a shielded area, cranes are used to remove the cask lid and unload TPBAR baskets from their shipping casks. Operations are monitored remotely using video camera systems. Unloaded baskets are moved to a TPBAR storage area. Empty casks are fitted with empty shipping/storage containers and the cask lid is re-installed. The cask is moved to the decontamination area, decontaminated and returned to the Utility.

The CLWR production capacity is assumed to be 4200 TPBARs per year ( -260 assemblies at 16 TPBARs/assembly). Each shipping basket is assumed to hold 300 TPBARs without baseplate, requiring 14 baskets per year, unless they are decontaminated and re-used. The baseline TPBARs are designed for Westinghouse and Babcock \& Wilcox reactors. They are $0.381^{\prime \prime}$ O.D. and 12 to $14.5 \mathrm{ft}$ in length, excluding the baseplate. Each TPBAR is assumed to weigh about $5 \mathrm{lb}$. and each baseplate about $10 \mathrm{lbs}$. Each TPBAR is assumed to contain approximately $1.0 \mathrm{gram}$ of tritium. TPBARs will also contain activation products and their outer surfaces may be coated with small amounts of activated corrosion products or "crud" from the commercial light water reactor. Due to the weight and high gamma activity expected, unloading of TPBAR baskets from the shipping cask will be performed remotely in a shielded area. 


\section{A1.2 TPBAR Storage}

CLWR-TEF provides shielded storage for both pre-extraction irradiated TPBARs and postextraction spent TPBARs. Failed TPBARs may also be stored pending evaluation, waste characterization and packaging for disposal. The shielded storage area is assumed to have an air atmosphere. All pre- and post-extraction operations will be done under secondary confinement. The secondary confinement may be under a nitrogen, argon or helium atmosphere.

Dry storage of irradiated TPBARs is assumed for the baseline conceptual design. Due to space limitations, the TEF is not designed for extended storage of spent TPBARs. (It may be necessary to store irradiated TPBARs in a water basin to facilitate removal of decay heat. In such a case, the proper water chemistry of the basin water must be maintained to prevent corrosion and pitting. Ion exchange beds and other filters may be employed.)

\section{A1.3 Cask/Trailer Decontamination}

The shipping trailer and casks are reusable and returned to the CLWR Utility for making multiple shipments. The outer surface of the casks must be smeared for contamination and decontaminated if necessary to meet DOT standards. The inside of the casks may need to be dried using a nitrogen gas purge. It is assumed that the cask inner surface does not need routine decontamination. Decontamination is assumed to employ an aqueous solution and one or more surfactants, although the solution chemistry remains to be determined. Liquid-less decontamination techniques may be investigated to minimize waste generation.

\section{A1.4 TPBAR/Cask Handling}

Irradiated CLWR TPBARs in their basket containers ans shipping casks must be unloaded from the shipping trailer or train. After unloading, they must be handled remotely in a shielded area due to the expected high level of gamma radiation. Due to the weight of the casks, baskets and TPBARs, remote crane operation is anticipated.

To prepare for furnace extraction, the baskets of irradiated TPBARs must be moved from the storage area to the TPBAR prep area. Then the TPBARs must be moved from the prep area to the furnace. Following extraction in a heated vacuum furnace, the TPBARs/baskets must be removed from the furnace, to be packaged for storage or direct shipment to waste disposal. The TPBAR/cask handling system is also used to move packages of spent TPBARs to the shielded storage area or retrieve them for shipment to the waste management facility.

Wastes from TPBAR/cask receipt, decontamination, handling and storage are included in the following waste streams described in Appendix B:

Job Control Waste (Extraction)

Nonhazardous Process Equipment (Extraction)

Ion Exchange Resin Beds (If Wet Storage)

Spent Filters (If Wet Storage) 


\section{A2. Tritium Extraction}

\section{A2.1 TPBAR Prep}

TPBAR assemblies or TPBARs must be prepared for extraction in a vacuum furnace. The TPBAR basket is lifted out of storage into a transporter. The transporter is connected to an inerting station where the air is displaced by nitrogen. The transporter is connected to the target prep module. The TPBAR basket is then lowered into the target prep module with the transporter still connected. The TPBAR basket lid installed at the Reactor is removed and will be handled as waste. In the target prep module, the TPBARs are individually cut to relieve gas pressure and prepare for extraction. Trapped gas composition in the irradiated TPBARs is described in a Pacific Northwest Lab report (PNL-81-33). Dust and debris generated during these operations are collected for contamination control using a HEPA filter. After all TPBARs have been cut, a furnace lid is placed over the basket. The lid contains filtration to prevent particulate from going into extraction piping. The TPBAR basket with the lid is raised into the transporter. The transporter is connected to the furnace module. The furnace basket is lowered into the furnace and the furnace lid is closed. The transporter is then removed from the furnace module.

(Although not planned, a chemical washing step may be necessary to remove oxide layers and/or crud deposits on the TPBARs, in order to cut down on the consumption of uranium beds in the post-extraction water cracking step. A liquid waste stream containing crud-contaminated cleaning solvent would be produced. This step requires further technical definition and process development.)

\section{A2.2 Furnace Extraction}

The basket of irradiated TPBARs is placed in a vacuum furnace system for extraction of tritium. The basket may also contain tritium getters and other tritium sources. The vacuum furnace is heated to extraction temperature by external electrical resistance heaters. Tritium, other hydrogen isotopes, helium and water vapor impurities are driven off by the heat. Volatile metals such as $\mathrm{Li}_{2} \mathrm{O}, \mathrm{LiOH}, \mathrm{LiOT}$ and $\mathrm{Zn}-65$ become particulate impurities in the process gas stream and must be condensed in a cold trap or filtered out using the basket lid. The furnace cover may have to be designed as a cold trap to remove volatile metals, as in the existing 232-H furnace. The cold trap may use process cooling water. The furnace cover contains gaskets or seals that must be accessible for maintenance/replacement, very likely for each furnace charge.

The furnace gases released during extraction are collected and analyzed for accountability of tritium from the TPBARs. Furnace heating is controlled so that the pressure of the gases escaping the heated TPBARs is kept low to minimize the tritium form diffusing into the furnace walls. When the gas evolution has decreased to an acceptable rate, a sweep gas (helium) is then added to purge the furnace.

The vacuum furnace and associated process equipment are installed in a module filled with nitrogen to contain any tritium that may leak out during insertion and removal of the baskets. A 
stripper system removes tritium from the recirculating containment box atmosphere. The furnace and accompanying shielding metal, if used, should be designed to last the 40-year design life of the facility. However, it is expected that some furnace heaters or heater elements will fail and need replacement during the life of the plant.

After extraction and cool-down, the basket containing the spent TPBARs is removed by the transporter and packaged for disposal as intermediate-level waste. Since the TPBAR basket is being designed to accommodate the dimensions of the E-Area Vaults Tritium silos, one basket of approximately 300 TPBARs will fit inside each silo. Thus, 14 silos will be needed for disposing of 4200 spent TPBARs each year. Overpacking of the spent TPBARs/baskets and/or use of a disposal container is assumed to be necessary. Disposal of the approximately 260 TPBAR baseplates at SRS depends on packing efficiency and may consume 5 or more silos each year.

Waste from TPBAR preparation and furnace extraction are included in the following waste streams described in Appendix B:

\author{
Spent TPBARs (Extraction) \\ TPBAR Baseplates (Extraction) \\ Job Control Waste (Extraction) \\ HEPA Filters (Extraction) \\ Nonhazardous Process Equipment (Extraction) (e.g., saw blades, laser windows) \\ Failed Furnace Components (Extraction) (e.g., Heating elements, furnace cover, gaskets) \\ Job Control Waste (Mixed Low-level Waste) \\ Mixed Waste Solvent Rags
}

\title{
A3. Tritium Processing
}

The product gas extracted by the furnace is purified to remove impurity gases from the hydrogen isotope gases (Tritium Purification). The hydrogen isotope gases then undergo isotopic separation (Tritium Separation) to produce tritium product of the desired quality. The tritium product is stored and delivered to the 233-H tritium loading facility, as needed.

Tritium purification consists of:

- Conversion of hydrogen isotopes to the elemental form

- Removal of inert impurity gases

- Removal of tritium from stack gas

\section{A3.1 Conversion of Hydrogen Isotopes to Elemental Form}

The tritium-rich furnace gas contains moisture (hydrogen oxides) from the TPBAR and ambient air humidity that must be converted to elemental hydrogen isotopes for further processing and purification. These oxide forms of hydrogen are converted or "cracked" to elemental hydrogen isotopes using an uranium bed. At elevated temperatures, the heated beds of depleted uranium react with hydrogen oxide to form uranium oxide and release elemental hydrogen isotopes. After 
cracking, the process gas is cooled and processed through a zeolite bed to remove unreacted hydrogen oxides (waters).

\section{A3.2 Removal of Impurity Gases}

Hydrogen isotopes are separated from $\mathrm{He}-3$ (caused by tritium decay), $\mathrm{He}-4, \mathrm{~N}_{2}$ and other impurity gases by permeation of the hydrogen isotopes through a palladium on kieselguhr flowthrough bed. Elemental hydrogen isotopes are gettered on palladium while inert gases pass through and are sent for further processing to the palladium-silver diffuser in 233-H to be installed under the Tritium Facilities Modernization and Consolidation Project. Following a cold absorption cycle to load hydrogen, the flow-through bed is heated to desorb high-purity hydrogen isotopes. The hydrogen isotope stream is then drawn through the bed by a mechanical pumping system to tanks or hydride storage beds in the product evacuation area. The product evacuation area consists of hydride storage beds, tanks and high vacuum headers which are connected to several of the process systems in the CLWR-TEF to remove hydrogen isotopes from the purification processes. The product evacuation area is also used to evacuate hydrogen isotopes from equipment in preparation for maintenance and to store hydrogen isotopes in the hydride storage beds until needed as feed to the Purification System. Upstream of the flow-through bed, the CLWR-TEF will provide by-pass capability for catalytically cracking ammonia in the process gas. Ammonia may be formed from the reaction of tritium with nitrogen inerting various gloveboxes, modules and transporters.

For background information, in the diffuser hydrogen isotopes diffuse through the heated tube wall into the shell and are evacuated to storage and isotopic separation. All other gases and byproducts ( $\mathrm{He}-3, \mathrm{Ar}, \mathrm{N}_{2}$, etc.) remain on the tube side and are drawn through the diffuser tubes by a vacuum pumping system to storage tanks.)

\section{A3.3 Removal of Tritium from Stack Gas}

Furnace flushes to be stacked, containing gases such as nitrogen, helium, ammonia and methane, may contain small quantities of tritium and usually cannot be released without treatment. This treatment will be done in a tritium process stripping system being provided under the Tritium Facilities Modernization and Consolidation Project in 233-H.

Wastes from tritium recovery systems are discussed in Appendix B under the following waste streams:

Job Control Waste (H-3)

Nonhazardous Process Equipment (H-3)

Nonhazardous Solvent

Hydride/Catalyst/Zeolite Beds

Uranium/Magnesium Beds

Nonhazardous Tritiated Oil 


\section{A4. Tritium Process Confinement and Clean-up Systems}

The CLWR-TEF will make use of the latest technology to enhance operational safety, ensure material safeguards and security, and prevent tritium losses to the environment. Past experience at SRS tritium facilities indicates that many significant waste streams do not come from the actual extraction and processing of tritium, but rather from maintenance activities. Prior to RTF, in the old 234-H loading facility and currently in the 232-H tritium extraction facility, maintenance operations utilize an "open" hood, requiring the use of protective clothing. This "plastic suit work" added significantly to the amounts of low-level waste generated. It is expected that almost all CLWR-TEF process systems are to be housed in enclosures designed to contain tritium leaks and allow recovery of the tritium. When processes are contained in glove boxes, routine maintenance operations can be performed through glove box ports without the use of a full-body plastic suit. These enclosures are maintained under negative pressure to prevent leakage of contaminated gases and can be filled with a blanketing gas atmosphere such as nitrogen to minimize the formation of tritium compounds that are prone to skin absorption (tritiated water or oil). Confinement box gases are discharged to a tritium stripping or clean-up system, which removes tritium from the effluent gas. A Z-Bed recovery system then recovers tritium from the stripper system. Implementing these design features, routine tritium release from the CLWR-TEF to the atmosphere should be less than historical tritium releases from 232-H.

\section{A4.1 Confinement Systems}

Confinement systems in the CLWR-TEF protect the environment and operating personnel from tritium release, radionuclide contamination and tritium uptake. The confinement systems are customized around individual processing module.

TPBAR preparation of puncturing the TPBAR cladding and cutting TPBARs into segments are expected to be conducted in a confined box. A filter system is expected to trap TPBAR prep debris. The extraction vacuum furnace is designed to capture tritium released from TPBARs, inleaked air and sweep gas. The furnace lid or cover may need to be designed with a condenser system to trap volatile metal vapors driven off by the furnace heat and vacuum. An outer tritium confinement box is also provided to minimize tritium releases.

Post-extraction tritium processing equipment will be confined in gloveboxes or hoods. Tritium processing equipment includes mechanical pumps, valves, tanks, uranium/magnesium beds, hydride storage beds, hydride pumps, hydride separators, glovebox stripper systems, tritium recovery systems and a Z-bed recovery system. The CLWR-TEF building HVAC will be sized to provide 150 linear feet per minute air velocity at glovebox and hood openings during normal operation and 200 linear feet per minute during open glovebox maintenance.

Acceptable tritium levels in processing areas are typically $<10^{-5} \mathrm{Ci} / \mathrm{m}^{3}$ in the rooms, or around the instrument sensitivity of Kanne chambers. Inside process gloveboxes, tritium levels are typically $<10^{-1} \mathrm{Ci} / \mathrm{m}^{3}$ during normal operation. Confinement boxes for TPBAR processing will probably experience higher levels of tritium. Glovebox gases are continuously processed through a tritium stripper system to remove tritium and other impurities. 


\section{A4.2 Tritium Clean-up and Recovery Systems}

The CLWR-TEF tritium clean-up or stripper systems remove tritium from Tritium Purification impurity gases prior to stacking and from the atmospheres of equipment enclosures such as gloveboxes and other confinements systems. The tritium clean-up or stripper systems use heated catalyst beds to oxidize hydrogen isotopes and their compounds to water. The water is then trapped by zeolite molecular sieve dryers. The effluent gases from the stripper systems may be stacked without significant environmental impact. Stackable tritium concentrations from the existing SRS Tritium Facilities are typically 5-10 ppm or less.

Tritium is a relatively benign radionuclide which becomes a much more significant hazard if absorbed inside the body through an uptake, where it can become incorporated as part of water or organic compounds. Exposure to tritium oxide (HTO) through inhalation or skin exposure is the most important type of tritium exposure because it results in the distribution of HTO throughout the soft tissue of the body. If tritiated hydrogen (HT) is inhaled, only a fraction is dissolved in the blood, and the rest is exhaled. Another hazard associated with tritium is its ability to diffuse into many substances, be converted into organic compounds, diffuse back to the surface, contaminate the surface, and be absorbed through the skin of a person touching the surface. Gloveboxes are blanketed with nitrogen to minimize the formation of HTO. However, air inleakage through the gloves and around glovebox panels/gaskets is unavoidable and has been found to be the major source of water trapped in the 233-H stripper systems.

Tritium, protium, nitrogen, oxygen, and water are the primary gas impurities in a blanketed glove box system. Tritium comes from leakage of the process equipment. Protium comes mainly from the moisture in the air which leaks into the glovebox or permeates through the gloves. Oxygen comes from air leaking in and permeation through the gloves. The oxygen level in a glove box is monitored and controlled at less than 1 vol. \% by adjusting the purge rate. More than $99.9 \%$ of the moisture in the system is expected to be from glovebox leaks and permeation through the gloves. All of this water is adsorbed in zeolite beds, along with a very small amount of tritiated water.

\section{Z-Bed Recovery System}

Unless the zeolite beds are treated and designed as single-use disposable beds, they need to be regenerated periodically by heating and flushing with a sweep gas. The recovered water is then decomposed to recover tritium and other hydrogen isotopes. The baseline Z-Bed recovery technology uses a magnesium bed (per RTF) to decompose water. The spent magnesium bed needs to be replaced and becomes a waste. Alternative recovery technologies include using a palladium membrane separator or solid oxide electrolysis. A regenerable iron oxide bed may also be used, but regeneration of the iron oxide uses hydrogen to produce a water vapor stream that is still contaminated by tritium, though to a much lesser extent. The first two technology process development opportunities are discussed in Section 5.6 of the main text of this report. 


\section{A4.3 Confinement Monitoring Systems}

Tritium air monitors and other instruments monitor the atmosphere in glovebox and confinement systems to ensure that they are performing to design specifications. These instruments may include oxygen analyzers (e.g., Teledyne Oxygen Sensor being in Building 233-H), tritium monitors (ion chambers or Kanne chambers), hydrogen monitors, continuous air monitors, betagamma radiation detectors, temperature sensors, and pressure controllers and gauges. Using conventional technology as in 233-H, the gloveboxes will be equipped with bubbler systems to provide catastrophic pressure relief and to seal gloveboxes against air intake.

Wastes from tritium process confinement and clean-up systems and monitors are discussed in Appendix B under the following waste streams:

Job Control Waste (H-3)

Job Control Waste (Depleted Uranium)

Nonhazardous Process Equipment (H-3)

Uranium/Magnesium Beds

Glovebox Bubbler Fluid

Nonhazardous Tritiated oil

Hydride/Catalyst/Zeolite Beds

Tritiated Water

Teledyne Oxygen Sensor Micro-fuel Cells

\section{A5. Tritium Analysis and Accountability}

\section{A5.1 Health Protection and Radiometric Laboratory}

Radiological Control (Rad Con) is responsible for conducting routine smears at SRS to monitor tritium and beta-gamma contamination in CLWR-TEF office and process areas. Scintillation and other counters are routinely used for this function. Smear samples are immersed in liquid scintillation cocktails to leach out tritium and produce detectable scintillations for measurement. Counting instruments must be calibrated periodically using standard mixtures such as P-10 counting gas. Rad Con also provides support for facility maintenance operations in contaminated process areas, sniffing of TPBAR casks at receipt, and decon operations.

Gas monitoring systems such as continuous air monitors (CAM's), Kanne monitors, ion chambers, and personnel protection monitors such as PCM-1B and hand-held radiation count rate meters (CRMs) are also the responsibility of Rad Con.

Rad Con operations will generate low-level waste and discharge chemical vapors to a chemical hood. Scintillation cocktails from analysis are discharged into a laboratory sink that feeds to the H-Area Effluent Treatment Facility. 


\section{A5.2 Mass Spectrometry and Accountability Measurement Lab}

Analytical Laboratories conduct routine analyses of process gas samples using mass spectrometry (mass spec) or gas chromatography to determine the gas composition needed for tritium accountability. Capillary lines are run from process sampling points and tanks to the mass spec lab. They must be evacuated and flushed between analyses. Sample bottles may also be used to take samples for analysis at the mass spectrometer. Sample bottles are reusable, but their outer surfaces must be decontaminated if they are removed from glovebox confinement.

Since tritium is a special nuclear material, periodic inventories must be undertaken. All tritium inventories in process/product tanks, hydride and other beds and process piping must be accounted for. Tritium in tanks is determined using the mass spec composition measurement and the tank pressure, volume and temperature (P-V-T-C). Tritium in hydride beds is determined using a flowing-gas calorimetric method and calibration data. Tritium product in small transportable containers may be determined using conventional calorimetry.

Non-routine radiological analyses are expected to be conducted in existing SRTC or Central Analytical Laboratory Facilities.

Waste from the CLWR-TEF mass spectrometry and accountability analytical laboratory may contain both radioactive and hazardous components, and is addressed in Appendix B under the waste stream called Analytical Laboratory Wastes.

\section{A5.3 Material Characterization Lab}

The CLWR-TEF Conceptual Design considered and rejected installing a hot cell analytical facility for examining irradiated TPBARs and preparing TPBAR samples for analysis. If such a need should arise, analyses are expected to be conducted in existing SRTC, vendor or other DOE material characterization laboratories. Such facilities may contain a number of chemicals, mechanical cutting tools, microscopes and video imaging systems. Sample processing will also require glass or metal containers, balances, shielding and glassware lab equipment.

\section{A5.4 Low-level Waste Assay}

Current SRS practice requires all identifiable radioactive waste streams to be covered by approved waste characterization plans prior to disposal. Due to the presence of gamma contaminants, the 21 " $\times 21$ " $\times 21$ " cardboard waste boxes and 55 gallon waste drums must be assayed to ensure that the waste stream characteristics are as projected in the waste characterization plans. An assay instrument is needed to conduct such measurements. Potential assay instruments include the Canberra $Q^{2}$ Low Level Waste Screening Monitor or a Pulse Height Analyzer.

Assay instrument calibration at SRS may also involve using a radioactive source. Assay instrument results are printed out as QA records and used as input to the solid waste manifest. Waste assay instrumentation is usually located near the Storage/Staging Area for B-25 waste boxes. 
Wastes from tritium analysis and accountability operations are discussed in Appendix B under the following waste streams:
Job Control Waste (H-3)
Job Control Waste (Extraction)
Nonhazardous Process Equipment (H-3)
Analytical Laboratory/Rad Con Chemicals
Tritiated Water and Aqueous Solutions

\section{A6. Balance of Plant Facilities}

CLWR-TEF balance-of-plant support facilities are described in this section. Each facility operation will also generate waste, as discussed below:

\section{A6.1 Electrical Power}

Electrical power is needed to operate process equipment (pumps, valves, etc.), lighting, heating, computers, controllers, Rad Con equipment and the building HVAC systems. Building electrical power for routine use is assumed to tap into the existing SRS power grid.

Standby electric power supply will be needed to provide short-term back-up power to support system loads in the event of a temporary failure of the electrical power supply. Standby power is provided by diesel generators or battery-based uninterruptible power supplies (UPS). UPS is provided for the CLWR-TEF Integrated Control System to sustain safety functions through the momentary power loss that occurs as the energy/standby source comes on-line following a loss of normal power. Burning of diesel during testing or prolonged operation will generate a waste air stream containing carbon dioxide, carbon monoxide and unreacted fuel. Servicing of the diesel and UPS will generate waste from replacement of non-working equipment parts such as switches and batteries.

Electric power consumption for the CLWR-TEF is estimated to be [TBD] kilo-watt-hours.

\section{A6.2 Steam}

Steam is commonly used at SRS to provide heating for building HVAC all year round. Steam tracing may also be used to prevent freezing of process lines outside of the building. The CLWRTEF project is currently considering using electrical heating instead of steam. If the CLWR-TEF should use steam, it is assumed that the steam line will connect to an existing steam header. Only low-quality ( $<200$ psig) steam is assumed to be necessary. Maintenance of the steam line will result in replacement of steam traps, valves, flow controllers and pressure gauges.

\section{A6.3 Domestic Water Supply}

Domestic water is used in the CLWR-TEF office areas, lunchroom, change rooms and rest rooms. The domestic water supply will tap into the existing plant system. Additional filtration may be needed near the connection point. Filters would require periodic replacement or cleaning. 
The domestic water usage will be based on operating staff level. CLWR-TEF is estimated to need about $1.95 \times 10^{6} \mathrm{gal} / \mathrm{yr}$ or $7,400 \mathrm{~m}^{3} / \mathrm{yr}$ of domestic water, based on an incremental staffing of 108 persons and use of 1,500 gallons per person per month. Domestic water supply may also be used to supply the process water and fire water tanks for the CLWR-TEF. These would be one-time demands with an occasional need for make-up water, assuming process water would be recirculated.

\section{A6.4 Sanitary Wastewater}

Used domestic water becomes sanitary wastewater. All CLWR-TEF generated sanitary or sewerage wastewater will be piped and pumped to a centralized Sanitary Wastewater Facility for treatment and release to the environment in accordance with the SRS National Pollutant Discharge Elimination System (NPDES) permit.

As with the domestic water usage, the annual sanitary wastewater is estimated to be $7,400 \mathrm{~m}^{3} / \mathrm{yr}$.

\section{A6.5 Process and Building Chilled Water}

Chilled water is used for cooling the building HVAC and for process cooling. Process cooling may include cooling of extraction furnace gas, furnace cover, zeolite beds and glovebox blanketing gas atmospheres. Hydride storage beds and the TCAP system also require cooling of the nitrogen gas heat transfer medium. This type of cooling system is currently used for hydride beds in 233-H, however, consideration is being given in this project to implementing direct water cooling of hydride beds as an alternative.

Process and building chilled water is usually recirculated and reused. To ensure efficient operation, the water chemistry must be properly maintained and particulates such as clay and corrosion products removed. Deionized and filtered water may have to be used for the cooling tower make-up.

Waste streams generated by maintenance of these systems include filters, expired chemicals and biocides.

\section{A6.6 Process Wastewater}

Process wastewater is collected and sampled before discharging to the Effluent Treatment Facility in H-Area or to the Tritium stormwater outfall. Sources of process wastewater include process cooling water slip streams, fluids collected in the floor drains in potentially contaminated areas, and Analytical Laboratory sinks where scintillation cocktails are discharged.

The process wastewater generation rate is estimated to be 1,000 gallons or $3.8 \mathrm{~m}^{3}$ per year.

\section{A6.7 Storm Sewer System}

The CLWR-TEF storm sewer collects, confines and channels the following non-radioactive liquid effluents from the CLWR-TEF building: rainfall from building roof drains and parking areas, nonprocess cooling water (e.g., cooling water used for breathing air compressor), cooling tower blowdown, steam condensate, discharge from the chiller makeup water expansion tanks and 
building floor drains. The CLWR-TEF Storm Sewer System collects these effluents and discharges to the Outfall H-002 in H-Area. The storm sewer effluent is sampled and analyzed before discharge at Outfall, as required by the NPDES permit.

Based on an assumed 3-acre site and capacity to remove $0.5 \mathrm{in} / \mathrm{hr}$ of heavy rainfall (12 inches in 24-hr period), the Storm Sewer System capacity is estimated to be about $700 \mathrm{gpm}$ :

\section{$0.5 \mathrm{in} / \mathrm{hr} \times 1 \mathrm{ft} / 12 \mathrm{in} \times 1 \mathrm{hr} / 60 \mathrm{~min} \times 3 \mathrm{acre} \times 43,560 \mathrm{ft}^{2} /$ acre $\times 7.48 \mathrm{gal} / \mathrm{ft}^{3}=678.8 \mathrm{gpm}$}

\section{A6.8 Fire Protection}

CLWR-TEF is provided with fire protection water systems and fire extinguishers. The fire protection water system will tap off the domestic water supply system.

Inadvertent discharge of fire protection water or planned discharge during testing is collected and disposed as process wastewater. Discharge of fire extinguishers will result in discharge of fumes and gasses to the building HVAC and require clean-up using rags and absorbent wipes.

\section{A6.9 Inert Gas Systems}

Inert gas systems include liquid nitrogen, low pressure nitrogen, instrument nitrogen, process flush nitrogen or hydrogen, liquid helium, helium, and argon gas.

Low-pressure nitrogen for blanketing gloveboxes will be provided from liquid nitrogen storage tanks and a vaporizer system. Higher pressure nitrogen, hydrogen and argon will be supplied from compressed gas cylinders. Compressed gas cylinders are generally located in clean areas and gases are piped into the process areas. Localized use of liquid nitrogen and liquid helium will be in portable Dewars.

Compressed gas cylinders are reusable and sent back to the vendor for refill. Cylinders reaching the end of their useful lives are generally treated as sanitary waste. During operation, pressure regulators, valves, fittings and tubing may need to be changed out as sanitary waste.

\section{A6.10 Plant, Instrument and Breathing Air}

Compressed instrument air is needed to operate instruments, solenoid valves and other controllers. Breathing and cooling air is supplied to persons conducting plastic suit operations.

Compressed instrument and breathing air may be supplied by a portable compressor or compressed air cylinder bottles. Instrument air is usually passed through a moisture dryer, a lubricator and a pressure regulator. The dryer is reusable, but the drying agent breaks down and may need to be replaced or made up periodically. During operation, pressure regulators, valves, fittings and tubing may need to be changed out as sanitary waste.

Compressed air and breathing air capability for the CLWR-TEF must be supplied at the required pressure of about 80-100 psig and an estimated total flow demand of [TBD] cfm. 


\section{A6.11 Building HVAC}

The CLWR-TEF building heating, ventilation and air conditioning systems provide climatic and humidity control inside the building. Building air flow is from regions of no radionuclide contamination (offices and change rooms) to low contamination (glovebox-contained tritium processing rooms) to higher contamination (extraction area). The required building air flow depends on free building volume outside of the gloveboxes and other confinement systems. Building air from the remote-handling area is HEPA filtered before discharging to the building stack. After change-out, dioctyl phthalate (DOP) is used to test HEPA filter efficiency. During normal operation, HVAC exhaust duct flow is measured using flow rate sensors such as Pitot tubes; they are also equipped with pressure drop indicators.

Wastes generated by the HVAC include duct work, gaskets and other maintenance parts, gauges, sensors and HEPA filters.

\section{A6.12 Process Heating/Cooling}

Process heating is usually provided electrically (for the extraction furnace, for example) or directly through steam. It may also be done indirectly though a gas or liquid heat transfer medium.

Process cooling may include cooling of extraction furnace gas, furnace cover, and glovebox blanketing gas atmospheres. Hydride storage beds and the TCAP system also require cooling of the nitrogen gas heat transfer medium. Consideration is being given in this project to implement direct water cooling of hydride beds. Process cooling may be achieved directly using chilled water or liquid nitrogen/helium or indirectly using a gas or liquid heat transfer medium to remove and reject waste heat to the environment. Gases may be cooled using a refrigeration system with a compressor (cryogenic still). Chilled water may be cooled using a cooling tower.

Process and building chilled water is usually recirculated and reused. To ensure efficient operation, the water chemistry must be properly maintained and corrosion products removed. Deionized and filtered water may have to be used for the cooling tower make-up.

Potential process heating/cooling waste streams have been previously cited under the Electrical System, Steam and Process and Building Chilled Water. Potentially hazardous wastes from the secondary cooling facilities are addressed in Appendix B under Cooling System and Maintenance Wastes.

\section{A6.13 Control Room/Integrated Control System}

The CLWR-TEF Control Room provides for integrated operational control and monitoring of the CLWR-TEF production systems, and associated support and safety systems. A central computer may be used with supervisory capability over local computers and the capability to independently monitor and control critical safety functions of each processing system. The central computer system will also monitor facility support systems. Control and monitoring capabilities may include:

- Operation, maintenance and engineering interfaces 
- Data acquisition

- Alarm management

- Data archiving and retrieval

- Real-time controls, hardware-based simulation

- Data distribution

- Self checking and diagnostics

Monitoring and control functions may also be available from local control stations located close to specified systems and sub-systems (distributed control systems or DCS's). These shall be used during system checkout, start-up, operation, shutdown, maintenance and other modes consistent with approved facility operating procedures.

Operation status boards, shift roundsheets, procedures and QA records may be stored in the Control Room. It may also provide for personnel monitoring and controlling access to and from restricted radiological areas. Operator training, including use of simulators, is assumed to be conducted in the existing SRS Central Training Facility in Building 766-H.

The Control Room will generate paper and other sanitary solid waste. Waste documents of a sensitive nature would need to be shredded or sent to classified scrap.

\section{A6.14 Offices and Change Rooms}

CLWR-TEF offices will house the administrative, technical support, and clerical staff. In addition, the CLWR-TEF may include a lunch room, rest rooms, bioassay stations, change rooms, data processing, and a records filing room.

Annual CLWR-TEF sanitary liquid waste is estimated to be $7,400 \mathrm{~m}^{3}$. Annual CLWR-TEF solid sanitary wastes from all CLWR-TEF clean areas is estimated to be $24,500 \mathrm{~kg} / \mathrm{yr}$, based on a generation rate of $2 \mathrm{lb}$./per person/per day, 250 working days a year and a staff of 108 . Assuming a bulk density of $0.15 \mathrm{~kg} /$ liter or $150 \mathrm{~kg} / \mathrm{m}^{3}$, waste volume is about $165 \mathrm{~m}^{3} / \mathrm{yr}$.

\section{A6.15 Safeguards and Security (S\&S)}

CLWR-TEF is protected by a number of safeguards and security measures. Successful entry to the facility may require passing through an explosive detection system, a metal detector system, a proximity card system, and guard stations. Some rooms are also controlled by cipher and combination locks. The CLWR-TEF is assumed to be located in the vicinity of the existing SRS Tritium Facilities. Thus, these safeguards and security measures are assumed to be part of the existing Tritium Facilities infrastructure.

The S \& S systems undergo periodic maintenance. Instrument parts are replaced as needed.

\section{A6.16 Emergency Services}

To address emergency situations or off-normal events that may arise, the CLWR-TEF is wired to communicate with the site Emergency Operations Office. Emergency lighting is provided 
throughout the facility to aid in facility evacuation in case of loss of lighting. This is particularly important since the facility is mostly located underground. Emergency medical and spill clean-up kits are also strategically positioned throughout the facility.

Waste may be generated from emergency medical treatment or clean-up of spills.

\section{A6.17 Tritium Equipment Decontamination Facility}

A tritium equipment decontamination facility is under consideration for inclusion in the CLWRTEF. DOE Order 6430.1A states that the facility design shall include a dedicated area furnished with appropriate equipment and utilities for decontamination of tools and as much equipment as practical. A variety of solvents, some containing RCRA hazardous components, are used as decontamination solutions. Paper and cloth wipes are used. Decontamination operations generate job control waste.

Decon wastes have the potential to contain both radioactive and hazardous components and are included in Appendix B under the various Job Control Waste streams, Mixed Waste Solvent Rags and Mixed and Hazardous Waste Oil/Solvent.

\section{A6.18 Communication Services}

To address emergency situations that may arise, the CLWR-TEF is wired to communicate with the site Emergency Operations Office. Public Announcement systems are located through out the facility. Offices and control rooms are wired for telephones and computer networking.

\section{A6.19 Maintenance Facilities}

Maintenance facilities provide shop and service areas for the CLWR-TEF. They also provide warehousing and materials handling for consumables and spare parts. Process equipment and piping manifolds may be fabricated, welded, prepared, or painted. Welded piping is $x$-rayed to check for weld integrity. Although new maintenance facilities may be built as part of the CLWRTEF, if the CLWR-TEF is built in the vicinity of the existing SRS Tritium Facilities, it is likely that existing maintenance facilities will be used.

Wastes generated in the Maintenance Facilities include metal piping, fittings, equipment parts, failed equipment, paint waste, and photographic waste.

\section{A6.20 Balance of Plant Waste Streams}

Most of the waste generated by the balance of Plant facilities will be non-hazardous and nonradioactive. Several of the waste stream possess potential for being hazardous, radioactive or mixed. The follow waste streams associated with the balance-of-plant facilities are discussed in Appendix B:

Job Control Waste (H-3)

Nonhazardous Solvent

Job Control Waste (Extraction)

Job Control Waste (Mixed Low-Level Waste) 
Tritiated Water and Aqueous Solutions

Nonhazardous Tritiated Oil

Mixed and Hazardous Waste Oil/Solvent 


\section{APPENDIX B \\ CLWR-TEF Waste Streams}

Appendix B contains a list of solid and liquid waste streams for the CLWR-TEF which have the potential to contain hazardous components, radioactive contamination, or both (mixed waste). Thus this appendix will identify and address hazardous, low-level, intermediate-level, and mixed low-level waste streams. The waste streams are identified based on the conceptual CLWR-TEF processes and anticipated operations described in Appendix A. Current SRS operating practice requires individual waste characterization plans to be developed for each low-level and mixed low-level waste stream. These waste characterization plans must be approved before waste may be shipped to the Solid Waste Management Division.

Each waste stream description contains the following information:

Type: Identifies a solid waste stream as either hazardous waste, low-level radioactive waste (LLRW), intermediate-level waste or mixed low-level waste (MLLW). Intermediate-level waste is a subset of low-level waste; it is used to designate low-level waste associated with spent irradiated Tritium Producing Burnable Absorber Rods (TPBARs) that emit greater than 200 $\mathrm{mRad} / \mathrm{hr}$ closed window reading at $5 \mathrm{~cm}$ from the container surface. Radioactive liquid waste streams are also identified. No high-level or transuranic (TRU) waste is expected to be generated by the CLWR-TEF.

Definitions of low-level radioactive waste and hazardous waste are given below. Mixed waste is waste that is both radioactive and hazardous. Thus one may have mixed lowlevel waste, mixed high-level waste and mixed TRU waste.

Low level radioactive waste (LLRW) is defined by the Low-level Radioactive Waste Policy Amendments Act as radioactive waste that is not:

- High-level radioactive waste

- Spent muclear fuel

- Byproduct material as defined in section IIE(2) of the Atomic Energy Act (uranium or thorium mill tailings)

$N R C$ classifies $L L R W$ based on the radionuclide content of the waste (1OCFR61.55). $L L R W$ is classified as either $A, B$ or $C$ based on the long-and short-lived radioactive materials in the waste.

A hazardous waste is a solid waste that is not excluded from regulation and either:

- Listed as hazardous under CFR261.31-33

Nonspecific source hazardous materials include spent solvents, electroplating wastes, metal heat-treating waste, chlorinated aliphatic manufacturing residues 
and waste from the proctuction or manufacturing of chlorophenolics. Specific source wastes include:

- Inorganic chemicals (waste water sludges, process residue, wastewaters)

- Secondary lead (emission control dust/sludge, waste leaching solution)

- Ink formulation (wastewater, solvent washes and sludges, wastewater treatment sludges)

- Wood preservation (wastewater treatment sludges)

- Inorganic pigments (wastewater treatment sludges, process residues)

- Organic chemicals (still bottoms, spent catalysts, process residue)

- Pesticides (wastewater treatment sludges, filter solids, still bottoms, byproduct salts, wastewaters)

There are 318 commercial products listed as hazardous: 216 hazardous (U-list) and 102 acutely hazardous (P-list).

- Mixed with a listed hazardous waste

- Exhibits any of the four characteristics of ignitability (D001), corrosivity (D002), reactivity (D003) or EPA toxicity (D004-D014).

- Derived from the Storage, Treatment or Dispasal of a hazardous waste, including:

- Sludges

- Treatment residue

- Ash

- Air emission control sludge/dust

- Leachate

A solid waste is any discarded material, in solid, liquid or gas form, not excluded by 40CFR261.4(a) or in the variance granted under 40CFR260.30-31. Discarded materials include materials that are abandoned, considered inherently waste-like or recycled. The following are excluded under 40CFR261.4(a) and are not considered solid wastes:

- Damestic sewage

- Waste discharged via public sewer to a publichy-owned treatment works

- Point source discharges subject to NPDES

- Irrigation return flows

- Waste subject to the Atomic Energy Act of 1954

- Wastes from in situ mining (when not removed from the ground)

- Unless accumulated speculatively,

- reclaimed pulping liquors that are re-used

- spent sulfuric acid used to produce virgin sulfuric acid

Description: Gives the waste stream physical matrix, EPA hazardous waste codes of RCRA components that may be present, source of radioactive contamination, radioactive isotopes and/or activity levels present.

Generation: Describes the process or activity that generates the waste stream. 
Handling and Packaging: Describes the current or recommended handling techniques and packaging practices for the waste stream to meet applicable Waste Management Facility Waste Acceptance Criteria (WAC).

Annual Quantities: Gives estimated annual generation rates in mass and volume. Quantities are based on the experience of DOE facilities with similar operations or using similar components, anticipated levels of production activities and/or engineering judgment. For reference, SRS Tritium Facilities actual waste shipped in FY96 and forecasted FY97-98 waste shipments (exclusive of Non-Nuclear Reconfiguration Project waste) are presented in Table B1.

Waste Minimization: Lists recommended methods for reducing or eliminating the waste stream. For potential mixed waste, lists recommendations for eliminating the hazardous component.

Treatment Options: Lists possible treatment technologies for LLRW or MLLW. Descriptions of the listed treatment technologies are given in Appendix C. It is assumed that hazardous waste which cannot be incinerated in the Consolidated Incineration Facility (CIF) will be packaged for treatment and/or disposal at a DOE-approved DOE or commercial waste management facility. One notable exception is corrosive-only hazardous waste that must be treated by the waste generator before disposal.

Comments: Provides additional information, which does not fit in the other categories, to help understand the nature of the waste stream or its treatment.

Seventeen different waste streams have been identified in this Appendix. Several waste streams have been subdivided to provide for expanded discussions of the waste stream components. DOE Order 6430.1 states that radioactive mixed waste shall be avoided where practical and that mixed waste that cannot be avoided shall be identified and considered in the facility design at the earliest possible time. In this Appendix, the identified mixed waste streams can all potentially be avoided. Thus the projected waste generation quantities for these mixed waste streams are either minimal or may be reduced further in practice. 
Table B1. SRS Tritium Facilities FY97-98 Waste Forecast* (Volumes in $\mathrm{ft}^{3}$ )

\begin{tabular}{|c|c|c|c|c|c|}
\hline & $\begin{array}{c}\text { Waste } \\
\text { Management } \\
\text { Facility } \\
\end{array}$ & $\begin{array}{c}\text { FY96 } \\
\text { (Actual) }\end{array}$ & FY97 & FY98 & Comments \\
\hline \multicolumn{6}{|l|}{ EXTRACTION (232-H) } \\
\hline Crucibles & ILTV Silos & $\mathbf{0}$ & 490 & 140 & $\begin{array}{l}35 \mathrm{ft}^{3} / \text { crucible; } 14 \\
\text { in FY97; } \\
4 \text { in FY98. }\end{array}$ \\
\hline Nonhazardous Equipment & ILTV Bulk Cell & 120 & 1,343 & 461 & $\begin{array}{l}\text { Includes } 150 \mathrm{LP}-50 \\
\text { storage containers } \\
\left(1103 \mathrm{f}^{3}\right)\end{array}$ \\
\hline $\begin{array}{l}\text { Job Control \& } \\
\text { Nonhazardous Equipment }\end{array}$ & LAW Vaults & 390 & 970 & 620 & $\begin{array}{l}700 \mathrm{ft}^{3} \text { of tritiated } \\
\text { secondary } \\
\text { containers in FY97 }\end{array}$ \\
\hline Job Control & CIF & 0 & 180 & 180 & \\
\hline Hazardous Waste & CIF & 5 & 49 & 16 & Methanol rags \\
\hline Mixed low-level & Interim Storage & 15 & 15 & 7 & $\begin{array}{l}\text { Freon rags from } \mathbf{U} \\
\text { bed preparation }\end{array}$ \\
\hline \multicolumn{6}{|l|}{ H-3 PURIFICATION } \\
\hline $\begin{array}{l}\text { Job Control } \\
(232-\mathrm{H}, 233-\mathrm{H}, 234-\mathrm{H}, 238-\mathrm{H})\end{array}$ & LAW Vaults & 14,500 & 10,500 & 10,500 & \\
\hline $\begin{array}{l}\text { Job Control } \\
(232-\mathrm{H}, 233-\mathrm{H}, 234-\mathrm{H}, 238-\mathrm{H})\end{array}$ & CIF & 6,500 & 10,500 & 10,500 & \\
\hline $\begin{array}{l}\text { Nonhazardous Equipment } \\
(232-\mathrm{H}, 233-\mathrm{H}, 234-\mathrm{H})\end{array}$ & ILTV Bulk Cell & 1,980 & 2,835 & 2,475 & $\begin{array}{l}\text { Includes } \mathrm{U} \text { beds, } \mathrm{Mg} \\
\text { beds, and } \mathrm{Z} \text { beds }\end{array}$ \\
\hline $\begin{array}{l}\text { Chiller Oil } \\
(232+\mathrm{H}, 233-\mathrm{H}) \\
\end{array}$ & CIF & 0 & 162 & 0 & $\begin{array}{l}\text { Halogens too high } \\
\text { for Power House }\end{array}$ \\
\hline $\begin{array}{l}\text { Tritiated Waste Oil } \\
(232-\mathrm{H}, 233-\mathrm{H}, 234-\mathrm{H})\end{array}$ & LAW Vaults & 0 & 88 & 88 & $\begin{array}{l}\text { Includes stored and } \\
\text { new waste oil }\end{array}$ \\
\hline $\begin{array}{l}\text { Hazardous Solvent } \\
(249-\mathrm{H})\end{array}$ & Interim Storage & 7 & 7 & 7 & $\begin{array}{l}\text { CFC-11 solvent \& } \\
\text { oil }\end{array}$ \\
\hline $\begin{array}{l}\text { Mixed Waste Equipment } \\
(232-\mathrm{H}, 233-\mathrm{H}, 234-\mathrm{H})\end{array}$ & Interim Storage & 90 & 100 & 100 & $\begin{array}{l}\mathrm{H} 8 \text { and } \mathrm{Pb} \\
\text { contaminated }\end{array}$ \\
\hline Mixed Oil (232-H, 234-H) & Interim Storage & 45 & 77 & 22 & $\mathrm{Hg}$ contaminated \\
\hline Mixed Job Control (233-H) & Interim Storage & 0 & 0 & 5 & Methanol rags \\
\hline Mixed Freon Rags (234-H) & Interim Storage & 0 & 32 & 0 & \\
\hline
\end{tabular}

- This table excludes waste forecast from the Non-Nuclear Reconfiguration Project.

Note: $A$ B-25 container is nominally $90 f^{\prime \prime}$ and a 21 " cubic cardboard box has a volume of $5.4 f^{\prime}$ 


\section{B1. Job Control Waste (H-3)}

\section{Type: Low-Level Radioactive Waste}

Description: Job Control Waste (JCW) is the predominant low-level waste stream by volume. JCW normally contains personal protective equipment (PPE) such as shoe covers, gloves, plastic suits, and air hoses. Other JCW includes kraft paper, sheet plastic, rags, absorbent wipes and tape used for radiological control and small equipment parts such as o-rings, gaskets, pipe fittings, broken glass test tubes and beakers.

Generation: Job Control Waste (H-3) is generated during production, maintenance, decontamination or housekeeping activities in the post-extraction tritium processing areas. Job Control Waste (H-3) is collected from all tritium-contaminated processing areas, with the exception of the extraction area (Extraction JCW is covered under a separate waste stream.). Tritium should be the only significant radioactive contaminant. It exists mostly as removable surface contamination. Tritium diffusion into cellulosic and plastic materials is usually negligible, due to the absence of a strong driving force (high temperature or tritium partial pressure). Once an item is contaminated, tritium may diffuse throughout the material. However, the total amount of tritium in the material will not increase as a result of diffusion.

Handling and Packaging: Depending upon tritium content, this waste stream is segregated into incinerable, compactible or non-compactible fractions based on waste form and the contamination level of the location where the waste was generated. Plastic and cellulosic items and most small metal items will be incinerated in the CIF. Incinerable or compactible waste, after bagging, is monitored for detectable offgassing tritium (greater than $4 \mathrm{E}-5 \mu \mathrm{Ci} / \mathrm{cc}$ ). To ensure that this criterion is maintained, waste from areas with tritium contamination greater than $3.7 \mathrm{E}+6 \mathrm{dpm}$ $\mathrm{H}-3 / 100 \mathrm{~cm}^{2}$ is segregated. Incinerable or compactible waste is packaged in 21 " $\times 21$ " $\times 21$ " cardboard radioactive waste boxes that are in good condition, and lined with a plastic bag. When a bag is full, it is monitored for offgassing tritium and surveyed for external surface contamination before shipment. Non-incinerable waste is placed in yellow or yellow-striped clear plastic radioactive waste bags. Closed waste packages are surveyed for offgassing tritium and for external contamination before being transferred to a B-25 box. Partially filled B-25 boxes are locked or stored inside a locked fence. Once a B-25 box is filled, it is closed and manifested for transportation to the E-Area Vaults (EAV) Low Activity Waste (LAW) Vaults for disposal.

Annual Quantities:

\begin{tabular}{|l|c|c|c|c|}
\hline & & Waste Destination & & \\
\hline $2,625 \mathrm{ft}^{3}$ & $24,400 \mathrm{lb}$ & CIF & $75 \mathrm{~m}^{3}$ & $10,000 \mathrm{~kg}$ \\
\hline
\end{tabular}

(a) Assume baseline of $21,000 \mathrm{ft}^{3}$ per year for 14 extractions and 233-H per Table B1.

(b) Per current practice, assume 2/3 for CLWR-TEF Extraction/Purification $\Rightarrow 14,000 \mathrm{ft}^{3}$. 
(c) Assume $\times 3$ for 42 extractions/year in CLWR-TEF $\Rightarrow 42,000 \mathrm{ft}^{3}$.

(d) Assume $\times 1 / 2$ for improved waste minimization practices in gloveboxes $\Rightarrow 21,000 \mathrm{ft}^{3}$.

(e) Assume $\times 1 / 2 \times 1 / 4$ for CL.WR-TEF H-3 Processing areas $=2,625 \mathrm{ft}^{3}$.

(f) Per current 233-H experience, assume 100\% incinerable to CIF. (Non-incinerable intems may be included in other job control waste streams.)

(g) Administrative limit of $50 \mathrm{lb}$ in $21^{\prime \prime} \times 21$ " $\times 21$ " box or $5.4 \mathrm{ft}^{3} \Rightarrow 9.3 \mathrm{lb} / \mathrm{ft}^{3}$ bulk density before compaction.

Waste Minimization:

(a) Process design changes can eliminate the potential for spills or pooling of cleaning solutions. Glovebox operation also eliminates the need for plastic suits, air hoses, etc., during maintenance and line breaks.

(b) Product substitution. For example, SRS evaluated the use of polyester wipes as a substitute for a product previously used in a variety of cleaning/decon situations. The polyester wipes were found to reduce the volume of generated wastes without diminishing performance and have been adopted for site-wide use.

\section{Treatment Options:}

(a) Incineration at CIF, followed by cement stabilization of ash/residue. Disposal of stabilized ash in the E-Area Vaults if passes TCLP; storage as mixed waste for further treatment if waste fails TCLP. (Note: SRTC does a modified TCLP using much less material (1-20 grams) than the 100 grams specified in the TCLP protocol. This is done to minimize waste generation.)

(b) Compaction for disposal in the EAV LAW Vaults.

(c) Direct disposal in the EAV LAW Vaults.

Comments:

(a) In a 1992 PWA, absorbent wipes made up $1 \%$ of a total waste of $25,457 \mathrm{ft}^{3}\left(721 \mathrm{~m}^{3}\right)$ at the SRS tritium processing facility (Ref: WSRC, "1992 Process Waste Assessment, Tritium Facility Low-level Waste," NMP-STE-93138, 8/13/93). Waste stream characteristics were estimated on the basis of purchasing records, observation of sample waste-handling activities, and interviews with operations personnel. 
(b) It may not be necessary to routinely assay this waste stream for gamma contamination; only tritium weak beta contamination is expected to be present. 


\section{B1a. Nonhazardous Solvents}

Type: Low-level Radioactive Waste.

Description: Residues of solutions used for decontamination, cleaning, or degreasing during equipment maintenance or repair. The solvents may become contaminated with radioactive or hazardous materials during the cleaning process

Generation: Routine maintenance, cleaning, degreasing, and decontamination activities.

Handling and Packaging: Pour onto rags and combine with Waste Stream B1.

Annual Quantities: Included in Waste Stream B1.

Waste Minimization:

Change to mechanical/physical stripping/cleaning devices to avoid solvent use.

Treatment Options: See Waste Stream B1.

Comments:

None. 


\section{B2. Job Control Waste (Depleted Uranium)}

Type: Low-level Radioactive Waste

Description; See Waste Stream B1.

Generation: JCW (Depleted Uranium Bed) is generated during production and housekeeping activities associated with loading and activation of the uranium beds. Depleted uranium turnings are shipped in an inerting medium to prevent oxidation. The fluid may be a Freon or oil. Tritium should be the only significant radioactive contaminant and exists mostly as removable surface contamination. Amounts of uranium isotopes also need to be manifested. Tritium diffusion into cellulosic and plastic materials is usually negligible, due to the absence of a strong driving force (high temperature or tritium partial pressure). Once an JCW item is contaminated, tritium may diffuse throughout the material. However, the total amount of tritium in the material will not increase as a result of diffusion.

Handling and Packaging: See Waste Stream B1.

Annual Ouantities:

\begin{tabular}{|l|l|c|r|r|}
\hline & & Waste Destination & & \\
\hline $180 \mathrm{ft}^{3}$ & $1700 \mathrm{lb}$ & CIF & $5 \mathrm{~m}^{3}$ & $770 \mathrm{~kg}$ \\
\hline
\end{tabular}

(a) Assume two sets of two parallel beds in CLWR-TEF ( 4 beds), preparing 2 beds each quarter, each preparation generates four 21 " $\times 21$ " $\times 21$ " boxes of waste/U bed $\Rightarrow 173 \mathrm{ft}^{3}$ :

(b) Assume baseline of $180 \mathrm{ft}^{3}$ per year for 14 extractions per Table B1.

(c) Assume 1/3 of waste from U bed preparation $\Rightarrow 60 \mathrm{ft}^{3}$.

(d) Assume $x 3$ for 42 extractions/year in CLWR-TEF $\Rightarrow 180 \mathrm{ft}^{3}$.

(e) Assume $100 \%$ to CIF, or $180 \mathrm{ft}^{3}$.

(f) Administrative limit of $50 \mathrm{lb}$ in 21 " $\times 21$ " $\times 21^{\prime \prime}$ box or $5.4 \mathrm{ft}^{3} \Rightarrow 9.3 \mathrm{lb} / \mathrm{ft}^{3}$ bulk density before compaction.

\section{Waste Minimization:}

(a) Product substitution. For example, SRS has investigated the use of polyester wipes as a substitute for a product previously used in a variety of cleaning/decon situations. The polyester wipes were found to reduce the volume of generated wastes without diminishing 
performance and has been adopted for site-wide use. Another example of product substitution is the use of nonhazardous solvents.

(b) Future plans at the SRS Tritium Facilities include replacing depleted uranium beds with pre-activated magnesium beds for both water cracking and Z-bed recovery, which will eliminate this waste stream.

\section{Treatment Options:}

(a) Incineration at CIF, followed by cement stabilization of ash/residue. Disposal of stabilized ash in the E-Area Vaults if passes TCLP; storage as mixed waste for further treatment if waste fails TCLP.

(b) Compaction for disposal in the EAV LAW Vaults.

\section{Comments:}

(a) Preparation of depleted uranium beds is currently done in a room or air hood. It cannot be done easily in gloveboxes, due to the large size and weight of loaded uranium beds. New bed preparation requires the use of a solvent to remove the blanketing medium applied over the depleted uranium prior to shipping. The blanketing medium or solvent may not be permitted in gloveboxes if they can potentially poison the glovebox stripper system catalyst.

(b) It is assumed that only nonhazardous fluids/solvents are used for inerting depleted uranium turnings and for uranium bed activation and clean-up. 


\section{B3. Job Control Waste (Extraction)}

Type: Low-level Radioactive Waste, Intermediate-level Waste

Description: See Waste Stream B1.

Generation: Job Control Waste (Extraction) is generated during production, maintenance, decontamination or housekeeping activities in the TPBAR extraction areas. Job Control Waste (Extraction) is collected from all processing areas exposed to TPBAR material and crud in the extraction area. Tritium is likely also to be present. All contaminants should exist as removable surface contamination.

Handling and Packaging: See Waste Stream B1.

Annual Ouantities:

\begin{tabular}{|r|r|c|r|r|}
\hline & & Waste Destination* & & \\
\hline $5,250 \mathrm{ft}^{3}$ & $48,800 \mathrm{lb}$ & CIF & $150 \mathrm{~m}^{3}$ & $20,000 \mathrm{~kg}$ \\
\hline $2,625 \mathrm{ft}^{3}$ & $24,400 \mathrm{lb}$ & Compaction/LAW Vaults & $75 \mathrm{~m}^{3}$ & $10,000 \mathrm{~kg}$ \\
\hline $2,625 \mathrm{ft}^{3}$ & $24,400 \mathrm{lb}$ & Direct to LAW Vaults & $75 \mathrm{~m}^{3}$ & $10,000 \mathrm{~kg}$ \\
\hline
\end{tabular}

*Intermediate-level waste would go to IITV Bulk Cell instead of LAW Vaults.

(a) Assume baseline of $21,000 \mathrm{ft}^{3}$ per year for 14 extractions and RTF per Table B1.

(b) Per current practice, assume $2 / 3$ for CLWR-TEF Extraction/Purification $\Rightarrow 14,000 \mathrm{ft}^{3}$.

(c) Assume $x 3$ for 42 extractions/year in CLWR-TEF $\Rightarrow 42,000 \mathrm{ft}^{3}$.

(d) Assume $x$ 1/2 for improved waste minimization practices in gloveboxes $\Rightarrow 21,000 \mathrm{ft}^{3}$.

(e) Assume 1/2 for CLWR-TEF Extraction areas $\Rightarrow 10,500 \mathrm{ft}^{3}$.

(f) Assume $50 \%$ to CIF, 25\% to Compaction/LAW Vaults, 25\% directly to LAW Vaults, or $5,250 \mathrm{ft}^{3}$ to CIF, $2625 \mathrm{ft}^{3}$ to Compaction/LAW Vaults, $2625 \mathrm{ft}^{3}$ to LAW Vaults.

(g) Administrative limit of $50 \mathrm{lb}$ in 21 " $\times 21$ " $\times 21^{\prime \prime}$ box or $5.4 \mathrm{ft}^{3} \Rightarrow 9.3 \mathrm{lb} / \mathrm{ft}^{3}$ bulk density before compaction.

(h) Assume compaction $4 \mathrm{x}$ volume reduction $\Rightarrow 656 \mathrm{ft}^{3}$ compacted waste to LAW Vaults.

Waste Minimization: See Waste Stream B1. 


\section{Treatment Options:}

(a) Incineration at CIF, followed by cement stabilization of ash/residue. Disposal of stabilized ash in the E-Area Vaults if passes TCLP; storage as mixed waste for further treatment if waste fails TCLP.

(b) Compaction for disposal in the EAV LAW Vaults.

\section{Comments:}

(a) In a 1992 PWA, absorbent wipes made up $1 \%$ of a total waste of $25,457 \mathrm{ft}^{3}\left(721 \mathrm{~m}^{3}\right)$ at the SRS tritium processing facility (Ref: WSRC, "1992 Process Waste Assessment, Tritium Facility Low-level Waste," NMP-STE-93138, 8/13/93). Waste stream characteristics were estimated on the basis of purchasing records, observation of sample waste-handling activities, and interviews with operations personnel.

(b) It will be necessary to assay this waste stream for beta-gamma contamination due to the presence of activated TPBAR material and "crud". 


\section{B4. Job Control Waste (Mired Low-Level Waste)}

Type: Mixed Low-level Radioactive, Hazardous

Description: See Waste Stream B1. Methanol and Freon are possible hazardous contaminants.

Many instrument computer boards also contain RCRA metals.

Generation: See Waste Stream B1.

Handling and Packaging: See Waste Stream B1.

Annual Quantities:

\begin{tabular}{|r|r|c|r|r|}
\hline & & Waste Destination & & \\
\hline $90 \mathrm{ft}^{3}$ & $840 \mathrm{lb}$ & Interim Storage/Off-site & $2.5 \mathrm{~m}^{3}$ & $380 \mathrm{~kg}$ \\
\hline $90 \mathrm{ft}^{3}$ & $840 \mathrm{lb}$ & CIF & $2.5 \mathrm{~m}^{3}$ & $380 \mathrm{~kg}$ \\
\hline
\end{tabular}

(a) Assume one B-25 container to CIF per year $\Rightarrow 90 \mathrm{ft}^{3}$.

(b) Assume one B-25 container to Interim Storage/Off-site per year $\Rightarrow 90 \mathrm{ft}^{3}$.

(c) Administrative limit of $50 \mathrm{lb}$ in $21^{\prime \prime} \times 21^{\prime \prime} \times 21^{\prime \prime}$ box or $5.4 \mathrm{ft}^{3} \Rightarrow 9.3 \mathrm{lb} / \mathrm{ft}^{3}$ bulk density before compaction.

Waste Minimization: See Waste Stream B1.

Treatment Options:

(a) Incineration at CIF for solvent rags, followed by cement stabilization of ash/residue.

(b) Thermal desorption followed by storage or disposal.

\section{Comments:}

(a) If listed material is incinerated, residue must be stabilized and disposed in a RCRA Subtitle C facility.

(b) While thermal desorption of volatile organics may convert a mixed waste to a low-level waste, if the off-gases are adsorbed on activated carbon, this becomes a secondary waste stream. 


\section{B5. Nonhazardous Process Equipment (H-3)}

\section{Type: Low-level Radioactive Waste}

Description: This waste stream consists of discarded process equipment or parts which provided primary tritium containment. It includes equipment such as vessels, tanks, pressure gauges, valves, fittings and secondary containers. Minor maintenance parts (e.g., small gaskets, bolts) are managed as Job Control Waste. This waste stream does not include tritium reservoir and high-pressure tritium processing tanks. All process equipment is non-incinerable and noncompactable due to physical form and potential tritium offgassing. Component tritium content may be assigned based on experimentally determined correlations (e.g., $0.05 \mathrm{Ci}$ of tritium per square foot of tritium-exposed surface.).

Generation: Nonhazardous Process Equipment (H-3) waste is generated by preventive and corrective maintenance of the post-extraction tritium processing systems, or by replacement of catalyst beds or containment devices.

Handling and Packaging: Tritium is removed from waste process equipment by flushing with purge gas or heating. Following removal from the process system and glovebox, waste equipment is stored in an engineered hood to control offgassing tritium within a monitored ventilation system. Management will review offgassing rate and facility conditions to determine when to dispose of process equipment. Following a period of off-gassing, the plastic-wrapped equipment will be placed into pre-approved containers (such as B-12 containers) for transport to the E-Area Vaults.

\section{Annual Quantities:}

\begin{tabular}{|c|r|c|r|r|}
\hline & & Waste Destination & & \\
\hline $90 \mathrm{ft}^{3}$ & $7,500 \mathrm{lb}$ & LAW Vaults & $2.5 \mathrm{~m}^{3}$ & $3,400 \mathrm{~kg}$ \\
\hline $90 \mathrm{ft}^{3}$ & $7,500 \mathrm{lb}$ & IITV Bulk Cell & $2.5 \mathrm{~m}^{3}$ & $3,400 \mathrm{~kg}$ \\
\hline
\end{tabular}

(a) Assume two B-12 containers per year to LAW Vaults $\Rightarrow 90 \mathrm{ft}^{3}$.

(b) Assume two B-12 containers per year to IITV Bulk Cell $\Rightarrow 90 \mathrm{ft}^{3}$

(c) Assume $75 \%$ void space, $50 \mathrm{vol} \%$ aluminum ( $2.7 \mathrm{SpG}$ ), 50 vol \% stainless steel (8.0 $\mathrm{SpG})=>90 \times 0.25 \times 62.3 \times(0.5 \times 2.7+0.5 \times 8) \sim 7,430 \mathrm{lb}$.

\section{Waste Minimization:}

(a) Use preventive maintenance to extend process equipment life. 
CLWR-TEF

Process Waste Assessment
WSRC-TR-96-0294

Rev. 1

$11 / 30 / 97$

(b) Decontaminate equipment and/or recycle metal.

(c) Use volume reduction techniques (cutting, compaction, etc.) to minimize final waste volume.

Treatment Options:

(a) Thermal desorption to remove as much tritium as practical.

(b) Offgassing in an engineered air hood to protect handling personnel.

(c) Depending on tritium content, waste equipment will be disposed of in either the LAW Vaults or the IITV Bulk Cell.

Comments: None.

B-15 


\section{B5a. Uranium/Magnesium Beds}

Type: Low-level Radioactive Waste.

Description: Uranium beds currently in use at SRS are about four feet long and two feet in diameter. The bed material is initially turnings of depleted uranium, but as the bed is used the material is oxidized to uranium oxide. Similarly, magnesium bed material is initially magnesium metal filings that oxidize to magnesium oxide as the bed is used. Both types of spent beds are contaminated with tritium. Spent depleted uranium beds also contain isotopes of uranium that must be manifested.

Generation: 1) Uranium beds are used to "crack" moisture in the extraction process gas leaving the furnace to elemental hydrogen isotopes. The reaction involves water reacting with uranium to form an oxide and release hydrogen isotopes. The cracked furnace gas then undergoes further gas separation to produced purified tritium. 2) In the Z-bed Recovery process, magnesium is consumed while cracking tritiated water to recover tritium adsorbed as tritiated water on zeolite beds. The zeolite beds are regenerated for reuse by heating and recirculating a carrier gas, which carries desorbed water or hydrogen oxides to heated uranium or magnesium beds. The hydrogen oxides react with magnesium to form a magnesium oxide and release hydrogen isotopes.

\section{Handling and Packaging:}

The outer bed surface is decontaminated and the beds are bagged for disposal in a B-12 container for shipment to the EAV Intermediate Level Tritium Vaults Bulk Cell.

\section{Annual Quantities:}

\begin{tabular}{|c|r|c|r|r|}
\hline & & Waste Destination & & \\
\hline $100 \mathrm{ft}^{3}$ & $4,400 \mathrm{lb}$ & $\begin{array}{c}\text { U Beds to IITV Bulk } \\
\text { Cell }\end{array}$ & $2.8 \mathrm{~m}^{3}$ & $2,000 \mathrm{~kg}$ \\
\hline $200 \mathrm{ft}^{3}$ & $3,760 \mathrm{lb}$ & $\begin{array}{c}\text { Mg Beds to IITV Bulk } \\
\text { Cell }\end{array}$ & $5.6 \mathrm{~m}^{3}$ & $1,710 \mathrm{~kg}$ \\
\hline
\end{tabular}

(a) Assume four beds in CLWR-TEF (two sets of two beds in parallel), and replacing 2 beds every quarter or 8 beds per year.

(b) Assume each $U$ bed is 2 feet O.D $\times 4$ feet long $\Rightarrow 12.6 \mathrm{ft}^{3}$.

(c) Assume $95 \%$ void space, uranium ( $\mathrm{SpG}=19) \Rightarrow-250 \mathrm{lb}$ each $\mathrm{U}$ bed. 
(d) Assume 24" Schedule 10 steel pipe container $(63.4 \mathrm{lb} / \mathrm{ft}) \Rightarrow 2250 \mathrm{lb}$. Plus $50 \mathrm{lb}$ for ends gives $\sim 300 \mathrm{lb}$ for total container weight. Total $\mathrm{U}$ bed weight $550 \mathrm{lb}$ each.

(e) Assume same number of $\mathrm{Mg}$ beds needed and $\mathrm{Mg}$ beds are sized 2x for same duty $\Rightarrow 25$ $\mathrm{ft}^{3} / \mathrm{Mg}$ bed.

(f) Assume $95 \%$ void space, magnesium (SpG=1.7) $\Rightarrow 130 \mathrm{lb}$ of $\mathrm{Mg}$ in each $\mathrm{Mg}$ bed.

(g) Assume 24" Schedule 10 steel container weighs $\sim 340 \mathrm{lb}$ each $\Rightarrow 470 \mathrm{lb} /$ loaded $\mathrm{Mg}$ bed.

Waste Minimization:

(a) Use of $\mathrm{Mg}$ beds is preferred over $\mathrm{U}$ beds for waste minimization; much less job control waste is generated in using the $\mathrm{Mg}$ beds.

(b) Investigates ways to minimize oxygen and moisture intrusion into glovebox atmosphere (number of penetrations, gloveports, gloves, gloveport covers, etc.) Oxygen and moisture will end up in the stripper zeolite beds and increase demand on the $\mathrm{Mg}$ beds.

(c) Similar to (b), reducing water/oxide formation on TPBARs and air inleakage into confinement systems will reduce $U$ bed usage.

\section{Treatment Options:}

Waste uranium or magnesium beds are sealed, self-contained units that can be packaged in gloveboxes under a nitrogen atmosphere for disposal. However, the uranium or magnesium must be completely oxidized to destroy its ignitability characteristic to meet disposal Waste Acceptance Criteria.

\section{Comments:}

SRS Tritium Facilities operating personnel prefer magnesium beds over uranium beds and are in the process of replacing the remaining uranium beds in 233-H Z-Bed Recovery System to magnesium beds. Uranium beds are still the baseline technology for cracking water coming out of the furnace due to concern about pressure drop. While uranium and uranium oxide are not hazardous or listed materials under RCRA, the depleted beds are a fire hazard because the finely divided powder that forms can ignite spontaneously in air. Magnesium beds are somewhat less reactive, but similar precautions should be used.

CLWR-TEF project personnel evaluated alternative regeneration technologies using palladium membrane reactor, solid oxide electrolysis and regenerable iron oxide beds. They were all considered to be insufficiently developed for deployment in the CLWR-TEF at this time. 


\section{B5b. Hydride/Catalyst/Zeolite Beds}

Type: Low-level Radioactive Waste.

Description: Hydride storage beds (e.g., LANA beds) currently in use at SRS are 4" in diameter and 3 feet long per unit. They have an inner container made of $3^{n}$ Schedule 40 stainless steel and an outer container made of 4" Schedule 10 stainless steel. Each unit has about 45 pounds of stainless steel in the container and 15 pounds of metal hydride material in the bed. LANA metal hydride storage bed packing material contains nickel, which is under heavy scrutiny as an environmental hazard and is on some state lists as a hazardous material. Waste hydride beds will contain residual tritium.

Platinum/Alumina catalyst beds are used to oxidize trace elemental tritium/hydrogen and organics to carbon dioxide and water in the glovebox/confinement gas stripper systems. The catalysts consist of pellets of finely dispersed platinum metal on an alumina substrate. Alumina is aluminum oxide, $\mathrm{Al}_{2} \mathrm{O}_{3}$, which is non-combustible and non-toxic. Waste catalyst beds will be contaminated with tritium.

Zeolite is either a naturally hydrated silicate of aluminum and either sodium or calcium or both of the type $\mathrm{Na}_{2} \mathrm{O}_{2} \mathrm{Al}_{2} \mathrm{O}_{3} \cdot \mathrm{nH}_{2} \mathrm{O}$; or an artificial ion exchange resin. Artificial zeolites are made in a variety of forms, ranging from gelatinous to porous and sand-like, and are used as gas adsorbents, water softeners, drying agents, and catalysts. Molecular sieves are a group of adsorptive desiccants which belong to the zeolite family. The outstanding characteristic of these materials is their ability to undergo dehydration with little or no change in crystal structure. The dehydrated crystals are interlaced with regularly spaced channels of molecular dimensions that comprise almost $50 \%$ of the total volume of the crystals. The empty cavities in an activated molecular sieve have a strong tendency to recapture the water molecules that have been driven off. Waste zeolite beds are containerized molecular sieve beads or pellets contaminated with tritium.

Catalytic cracker is a catalyst used for processing ammonia formed from nitrogen in glovebox/confinement gases reacting with tritium. Commercial ammonia crackers are based on iron or nickel catalysts supported on a substrate such as alumina.

Generation: LANA hydride beds currently in use for storing tritium have a tendency to trap the helium-3 decay product of tritium. It is assumed that helium buildup will eventually lead to hydride bed failure and need for replacement. The expected LANA hydride bed lifetime is about five years.

Stripping systems are used to recover tritium from waste gases before they are sent to the stack. These stripper systems operate by pumping the gas over a heated PUAlumina catalyst bed (Engelhard Deoxo D) to oxidize the molecular hydrogen isotopic species to tritiated water. The resulting tritiated water, regular water, and HTO are then adsorbed by the molecular sieve in the 
zeolite beds. The molecular sieve can be regenerated and reused until a physical breakdown in the material necessitates its replacement. At that time the entire unit, the container and the molecular sieve, will be replaced.

Catalytic crackers operate at elevated temperatures that may lead to sintering and gradual performance degradation. There is a need for eventual replacement after pro-longed operation. A service life in excess of 10 years is estimated for these catalytic crackers.

Handling and Packaging: Tritium is removed from waste hydride/catalyst/zeolite/catalytic cracker equipment by flushing with purge gas, heating, and/or isotopic exchange. Hydride and catalyst beds need to be passivated and isolated. Following removal from process, process equipment may be stored in engineered air hoods or gloveboxes to control offgassing tritium within a monitored ventilation system. Management will review offgassing rate and facility conditions to determine when to dispose of process equipment. Following a period of off-gassing, spent beds are wrapped in plastic bags (heavy duty polyurethane) and placed into pre-approved containers (e.g., B-12 containers) for disposal in the E-Area Vaults.

\section{Annual Ouantities:}

\begin{tabular}{|l|r|c|r|r|}
\hline & & Waste Destination & & \\
\hline $4.8 \mathrm{ft}^{3}$ & $120 \mathrm{lb}$ & $\begin{array}{c}\text { Hydride Beds to LAW } \\
\text { Vaults }\end{array}$ & $0.14 \mathrm{~m}^{3}$ & $55 \mathrm{~kg}$ \\
\hline
\end{tabular}

(a) Assume two hydride beds per year after 5 years of operation; no 233-H hydride bed has been disposed as waste after 5 years of RTF operation.

(b) Assume each jacketed hydride bed is 12 in $0 . D$. $\times 3$ feet long $\Rightarrow 2.4 \mathrm{ft}^{3}$

(c) Assume each bed is about $45 \mathrm{lb}$ container and $15 \mathrm{lb}$ metal hydride. Container weight check:

Outer container: 3" Schedule 40 steel pipe $(7.6 \mathrm{lb} / \mathrm{ft}) \times 3 \mathrm{ft}=22.8 \mathrm{lb}$.

Inner container: $4^{\mathrm{n}}$ Schedule 10 steel pipe $(5.6 \mathrm{lb} / \mathrm{ft}) \times 3 \mathrm{ft}=16.8 \mathrm{lb}$.

(d) Assume no routine waste catalyst and $Z$ beds; they are expected to last the design life of the CLWR-TEF of 40 years.

\section{Treatment Options:}

(a) Hydride and catalyst beds must be passivated to eliminate potential for spontaneous combustion. The entire containerized units are packaged for disposal without removing the packing materials. 
(b) Zeolite beds are thermally desorbed to Z-Bed Recovery. Isotopic swamping or exchange may be desirable to recover tritium prior to disposal.

Waste Minimization:

No waste minimization efforts have been identified.

\section{Comments:}

(a) The SRS Tritium Facilities currently has 10-15 hydride beds in use, with an estimated 2 to 3 beds requiring replacement each year. LANA hydride bed service life is expected to be 5 years or more.

(b) As they are cycled, metal hydrides become finely divided powders that are potentially pyrophoric.

(c) When metal hydrides are used for tritium capture and storage, it is uncertain whether the hydrides can reduce the tritium concentration in the waste gas to the 5 to 10 parts per million achieved during cryogenic distillation.

(d) In 233-H, type 3A zeolite is used in the Stripper System zeolite beds. Since zeolite 3A does not adsorb $\mathrm{CO}_{2}$, the $\mathrm{CO}_{2}$ generated by the oxidation of organics goes out with the purge gas and does not accumulate in the zeolite beds.

(e) At TSTA the same molecular sieve was used for 10 years (not continuous use). The material was then replaced, not because of failure, but to investigate hold-up tritium on the bed. 


\section{B6. Spent TPBARs (Ertraction)}

Type: Intermediate-level Waste.

Description: Basket containers [of TBD material of construction] are used to hold irradiated TPBARs (Tritium Producing Burnable Absorber Rods) for tritium extraction using a furnace. The components of the TPBAR will have been activated as a result of neutron capture during irradiation in the nuclear reactor. Irradiated TPBARs will emit a photon spectrum of multiple energies (source term) from the radioactive decay of these activation products. This radioactive decay will generate decay heat in the TPBAR. During furnace extraction, the extraction baskets become contaminated with radioactive constituents present in the TPBAR and crud materials, including tritium. TPBARs are not melted to any significant degree during extraction. Spent, post-extraction TPBARs and extraction basket are disposed of together as waste after each furnace charge. The radioactive characteristics of this waste is dominated by the composition of the irradiated TPBARs. Composition characterization data for CLWR TPBARs calculated by PNNL using the ORIGEN2 code are given in Table B2.

Generation: Punctured CLWR TPBARs are placed in an extraction basket and heated in a furnace to extract tritium. During furnace extraction, the released tritium gas is pumped from the enclosed furnace for subsequent purification. Some volatile metals such as LiOH from the irradiated TPBARs will also be vaporized during extraction. After extraction, the spent TPBARs contain only residual amounts of tritium, assumed to be less than $5 \%$ of the tritium originally present. Most of the other radionuclides in the spent TPBARs are expected to remain in the metal matrix. There are an estimated four Lead Test Assemblies (LTAs) which will be processed on a one-time basis. If the CLWR should become the preferred technology for tritium production, approximately 14 Production Assembly extraction charges are expected to be processed each year (4200 TPBARs@ 300 TPBARs per charge).

Handling and Packaging: Waste must be surveyed for gamma radiation field and packaged to meet the handling requirements of the waste disposal facility. A shipping cask and overpack will need to be developed for transporting spent TPBARs and baskets to Waste Management. The cask may be re-used if the extraction basket container can meet WAC3.17 for the EAV. A number of radionuclides in the TPBAR may exceed WAC3.17 ILTV/silo limits: C-14, Ni-59 and Tc-99. Packaging design may need to be developed to overcome these limitations, unless a refined waste performance assessment can raise these limits.

Annual Quantities:

\begin{tabular}{|l|c|c|r|r|}
\hline & & Waste Destination & & \\
\hline $490 \mathrm{ft}^{3}$ & $35,000 \mathrm{lb}$ & ILTV Silos & $14 \mathrm{~m}^{3}$ & $16,000 \mathrm{~kg}$ \\
\hline
\end{tabular}

(a) Assume one basket/charge of 300 TPBARs (full length) each per ILTV silo. 
(b) Approximately 4,200 TPBARs will be disposed of in 14 silos.

(c) Each silo is nominally $35 \mathrm{ft}^{3} \Rightarrow 490 \mathrm{ft}^{3} / \mathrm{yr}$.

(d) Each TPBAR weighs about $5 \mathrm{lb} \Rightarrow 21,000 \mathrm{lb}$. of TPBARs.

(e) Assume containers made from 12" schedule 10 S steel pipe $(24.2 \mathrm{lb} . / \mathrm{ft}) \Rightarrow 375$ $\mathrm{lb} . /$ container of $15.5 \mathrm{ft}$ length.

(f) Assume each lid or plug weighs $75 \mathrm{lb}$. $\Rightarrow 450 \mathrm{lb}$./container or $-6,300 \mathrm{lb}$. for 14 containers.

(f) Add $\sim 100 \%$ or $6,200 \mathrm{lb}$. for spent TPBAR/basket overpack $\Rightarrow 12,500 \mathrm{lb}$.

(g) Total waste/container weight $=21,000+12,500=33,500 \mathrm{lb}$. Round off to $35,000 \mathrm{lb}$. Waste Minimization:

(a) There is no feasible alternative to the use of extraction baskets in this process.

(b) Physically, each basket may hold 400 or more TPBARs. This would save 3 silos a year but will involve more handling.

\section{Treatment Options:}

None required.

\section{Comments:}

(a) In the past, hollow LiAl pieces in open crucibles (equivalent of the extraction baskets) would reduce in volume in the furnace and the crucibles were used twice before being discarded. The new TPBAR is not expected to melt at the proposed extraction temperatures.

(b) It is assumed that the extraction baskets may be used as waste containers for spent TPBAR disposal. 
Table 2. Radionuclide Characteristics of CLWR TPBAR (Ci/TPBAR)

\begin{tabular}{|c|c|c|c|c|c|c|c|c|c|}
\hline $\begin{array}{l}\text { Radio- } \\
\text { nuclide }\end{array}$ & Half-Life & $\begin{array}{l}\text { Decay } \\
\text { Mode }\end{array}$ & $\begin{array}{c}7 \\
\text { Days }\end{array}$ & $\begin{array}{c}30 \\
\text { Days }\end{array}$ & $\begin{array}{c}90 \\
\text { Days }\end{array}$ & $\begin{array}{c}180 \\
\text { Days }\end{array}$ & $\begin{array}{c}1 \\
\text { Year }\end{array}$ & $\begin{array}{c}3 \\
\text { Years }\end{array}$ & $\begin{array}{c}10 \\
\text { Years }\end{array}$ \\
\hline $\mathrm{H}-3$ & $.33 y$ & Beta & $1.16 \mathrm{E}+04$ & $1.16 \mathrm{E}+04$ & $1.15 \mathrm{E}+04$ & $1.13 E+04$ & $1.10 \mathrm{E}+04$ & $9.84 \mathrm{E}+03$ & $6.64 \mathrm{E}+03$ \\
\hline C-14 & $5730 y$ & Beta & $8.91 \mathrm{E}-03$ & $8.91 \mathrm{E}-03$ & $8.91 \mathrm{E}-03$ & $8.91 \mathrm{E}-03$ & $8.91 \mathrm{E}-03$ & $8.91 \mathrm{E}-03$ & $8.91 \mathrm{E}-03$ \\
\hline $\mathrm{Na}-24$ & $15 \mathrm{~h}$ & Beta & $1.22 \mathrm{E}-03$ & $1.02 \mathrm{E}-14$ & $0.00 \mathrm{E}+00$ & $0.00 \mathrm{E}+00$ & $0.00 \mathrm{E}+00$ & $0.00 \mathrm{E}+00$ & $E+00$ \\
\hline $\mathrm{Cr}-51$ & & Gamma & $4.27 E+02$ & $2.40 \mathrm{E}+02$ & $5.36 \mathrm{E}+01$ & $5.64 \mathrm{E}+00$ & $5.48 \mathrm{E}-02$ & 6.34E-10 & $0.00 \mathrm{E}+00$ \\
\hline $\mathrm{Mn}-54$ & $312.2 \mathrm{~d}$ & Gamma & $2.06 \mathrm{E}+01$ & $1.96 \mathrm{E}+01$ & $1.72 \mathrm{E}+01$ & $1.41 \mathrm{E}+01$ & $9.32 \mathrm{E}+00$ & $1.84 \mathrm{E}+00$ & -03 \\
\hline Fe-55 & & e-capture & $1.05 E+02$ & $1.03 \mathrm{E}+02$ & $9.84 \mathrm{E}+01$ & $9.21 E+01$ & $8.05 \mathrm{E}+01$ & $4.72 E+01$ & 7.3 \\
\hline $\mathrm{Fe}-59$ & & Beta/y & $9.28 \mathrm{E}+00$ & $6.51 E+00$ & $2.59 \mathrm{E}+00$ & $6.46 \mathrm{E}-01$ & $3.73 E-02$ & $4.84 \mathrm{E}-07$ & -24 \\
\hline Co-58 & & Gamma & $7.22 \mathrm{E}+01$ & \begin{tabular}{|l|}
$5.76 \mathrm{E}+01$ \\
\end{tabular} & $3.20 \mathrm{E}+01$ & $1.33 \mathrm{E}+01$ & $2.16 \mathrm{E}+00$ & E-03 & $\mathrm{E}-14$ \\
\hline $\mathrm{Co}-60$ & & Bet & 3.22 & 3.2 & +01 & $E+01$ & $2.83 \mathrm{E}+01$ & +01 & +00 \\
\hline Ni-59 & $7.6 \mathrm{E} 4 \mathrm{y}$ & e-captu & $2.18 \mathrm{E}-02$ & \begin{tabular}{|l|}
$2.18 \mathrm{E}-02$ \\
\end{tabular} & $2.18 \mathrm{E}-02$ & $2.18 \mathrm{E}-02$ & $2.18 \mathrm{E}-02$ & $2.18 \mathrm{E}-02$ & $3 \mathrm{E}-02$ \\
\hline $\mathrm{i}-63$ & & Beta & $3.52 \mathrm{E}+00$ & 3.5 & +00 & $\mathrm{E}+00$ & $3.50 \mathrm{E}+00$ & & +00 \\
\hline $\mathrm{Cu}-64$ & $7 \mathrm{~h}$ & Beta/y & $7.80 \mathrm{E}-04$ & $6.43 \mathrm{E}-17$ & $0.00 \mathrm{E}+00$ & $0.00 \mathrm{E}+00$ & $0.00 \mathrm{E}+00$ & +00 & +00 \\
\hline$n-65$ & & $\mathrm{Be}$ & $2-03$ & -03 & $2-03$ & $\mathrm{E}-03$ & $6.13 \mathrm{E}-04$ & -05 & -08 \\
\hline Sr-89 & sd & Beta & $2.50 \mathrm{E}-02$ & $1.82 \mathrm{E}-02$ & $8.00 \mathrm{E}-03$ & $2.33 \mathrm{E}-03$ & $1.83 \mathrm{E}-04$ & -09 & \\
\hline$Y-89 m$ & & IT & $2.80 \mathrm{E}-04$ & -06 & $8-12$ & $\mathrm{E}-20$ & $0.00 \mathrm{E}+00$ & +00 & +00 \\
\hline$Y-90$ & $d$ & Beta & $1.68 \mathrm{E}-01$ & 4.2 & $8-07$ & $6.39 E-07$ & $6.31 \mathrm{E}-07$ & $3-07$ & \\
\hline$Y-91$ & & Beta & $6.42 \mathrm{E}-02$ & -02 & $2-02$ & E-03 & IE-04 & -07 & -20 \\
\hline Zr-89 & & $\begin{array}{l}\text { e- car } \\
\text { Beta }\end{array}$ & -04 & -06 & $8-12$ & $\mathrm{E}-20$ & $2.80 \mathrm{E}-37$ & $\overline{0.0}$ & \\
\hline $\mathrm{Zr}-93$ & $E+6 y$ & Beta/y & $1.07 E-04$ & $3-04$ & $2-04$ & E-04 & $1.07 \mathrm{E}-04$ & E-04 & -04 \\
\hline Zr-95 & & Bet & $2.94 \mathrm{E}+01$ & 2.29 & +01 & $E+00$ & E-01 & & \\
\hline $2 r-97$ & $3 \mathrm{~h}$ & Bet & $5.27 \mathrm{E}-02$ & $7.75 \mathrm{E}-12$ & $0.00 \mathrm{E}+00$ & $0.00 \mathrm{E}+00$ & $0.00 \mathrm{E}+0.0$ & +00 & +00 \\
\hline $\mathrm{Nb}-92$ & $8 y$ & $\mathrm{Ga}$ & & & 204 & $2-06$ & E-12 & 34 & +00 \\
\hline $\mathrm{Nb}-93 \mathrm{~m}$ & & $\overline{I T}$ & $3.78 \mathrm{E}-06$ & -06 & $4.91 \mathrm{E}-06$ & $6.12 \mathrm{E}-06$ & $8.57 \mathrm{E}-06$ & -05 & -05 \\
\hline $\mathrm{Nb}-94$ & $+4 y$ & Beta & & & & $2-04$ & E-04 & & -04 \\
\hline $\mathrm{Nb}-95$ & & Bet & $3.12 \mathrm{E}+01$ & 2.92 & $1.99 \mathrm{E}+01$ & $8.89 \mathrm{E}+00$ & $1.32 \mathrm{E}+00$ & -04 & -16 \\
\hline $\mathrm{Nb}-95 \mathrm{~m}$ & $d$ & Beta & $2.17 \mathrm{E}-01$ & -01 & $8.87 \mathrm{E}-02$ & $E-02$ & $4.50 \mathrm{E}-03$ & -06 & $2-18$ \\
\hline $\mathrm{Nb}-96$ & & Bet & $4.06 \mathrm{E}-04$ & $2-11$ & E-30 & $8+00$ & $E+00$ & $8+\infty$ & +00 \\
\hline $\mathrm{Nb}-97$ & & Beta/y & $5.30 \mathrm{E}-02$ & $8.35 \mathrm{E}-12$ & $0.00 \mathrm{E}+00$ & $0.00 \mathrm{E}+00$ & $0.00 \mathrm{E}+00$ & $0.00 \mathrm{E}+00$ & $+\infty$ \\
\hline $\mathrm{Nb}-97 \mathrm{~m}$ & & $\mathbf{I T}$ & & $7.34 \mathrm{E}-12$ & $0.00 \mathrm{E}+00$ & $0.00 \mathrm{E}+00$ & $0.00 \mathrm{E}+00$ & $0.00 \mathrm{E}+00$ & $+\infty$ \\
\hline $\mathrm{Mo-93}$ & $8+3$ & - capt & $6.93 \mathrm{E}-04$ & $6.93 \mathrm{E}-04$ & $6.93 \mathrm{E}-04$ & $6.93 \mathrm{E}-04$ & $6.93 \mathrm{E}-04$ & $\mathrm{E}-04$ & $8-04$ \\
\hline Mo-99 & $5 \mathrm{~d}$ & Betaly & $6.16 \mathrm{E}+01$ & $1.87 \mathrm{E}-01$ & $5.05 \mathrm{E}-08$ & $7.10 \mathrm{E}-18$ & $6.66 \mathrm{E}-38$ & $0.00 \mathrm{E}+00$ & $0.00 \mathrm{E}+00$ \\
\hline Tc-99 & $E+5 y$ & Beta & $1.81 \mathrm{E}-04$ & $1.82 \mathrm{E}-04$ & $1.82 \mathrm{E}-04$ & $1.82 \mathrm{E}-04$ & $1.82 \mathrm{E}-04$ & $1.82 \mathrm{E}-04$ & $1.82 \mathrm{E}-04$ \\
\hline $\mathbf{R u}-103$ & & Beta & $1.37 \mathrm{E}-03$ & $9.13 \mathrm{E}-04$ & $3.17 \mathrm{E}-04$ & $6.47 \mathrm{E}-05$ & $2.46 \mathrm{E}-06$ & $6.21 \mathrm{E}-12$ & E-31 \\
\hline $\mathrm{In}-113 \mathrm{~m}$ & $1.66 \mathrm{~h}$ & Gamma & $7.10 \mathrm{E}-01$ & $6.18 \mathrm{E}-01$ & $4.31 \mathrm{E}-01$ & $2.50 \mathrm{E}-01$ & $8.21 \mathrm{E}-02$ & $1.01 \mathrm{E}-03$ & $2.08 \mathrm{E}-10$ \\
\hline In-114 & & Gamma & & $3.67 \mathrm{E}-02$ & $1.58 \mathrm{E}-02$ & $4.49 \mathrm{E}-03$ & $3.36 \mathrm{E}-04$ & $1.22 \mathrm{E}-08$ & $3.47 \mathrm{E}-24$ \\
\hline In-114m & $1.84 \mathrm{~m}$ & $\overline{\beta+}$ & $5.29 \mathrm{E}-02$ & $3.83 \mathrm{E}-02$ & $1.65 \mathrm{E}-02$ & $4.69 \mathrm{E}-03$ & $3.51 \mathrm{E}-04$ & $1.27 \mathrm{E}-08$ & $3.63 \mathrm{E}-24$ \\
\hline
\end{tabular}


Table 2. Radionuclide Characteristics of CLWR TPBAR (Ci/TPBAR) (Cont'd)

\begin{tabular}{|c|c|c|c|c|c|c|c|c|c|}
\hline $\begin{array}{l}\text { Radio- } \\
\text { nuclide }\end{array}$ & Half-Life & $\begin{array}{l}\text { Decay } \\
\text { Mode }\end{array}$ & $\begin{array}{c}7 \\
\text { Days } \\
\end{array}$ & $\begin{array}{c}30 \\
\text { Days }\end{array}$ & $\begin{array}{c}90 \\
\text { Days }\end{array}$ & $\begin{array}{l}180 \\
\text { Days }\end{array}$ & $\begin{array}{c}1 \\
\text { Year } \\
\end{array}$ & $\begin{array}{c}3 \\
\text { Years } \\
\end{array}$ & $\begin{array}{c}10 \\
\text { Years } \\
\end{array}$ \\
\hline $\mathrm{Sn}-113$ & $115.1 \mathrm{~d}$ & Gamma & $7.09 \mathrm{E}-01$ & $6.17 \mathrm{E}-01$ & $4.30 \mathrm{E}-01$ & $2.50 \mathrm{E}-01$ & $8.20 \mathrm{E}-02$ & $1.01 \mathrm{E}-03$ & $2.07 \mathrm{E}-10$ \\
\hline $\mathrm{Sn}-117 \mathrm{~m}$ & $13.6 \mathrm{~d}$ & Gamma & $4.48 \mathrm{E}+00$ & $1.44 \mathrm{E}+00$ & $7.37 \mathrm{E}-02$ & $8.57 \mathrm{E}-04$ & $8.93 \mathrm{E}-08$ & $1.77 \mathrm{E}-23$ & $0.00 \mathrm{E}+00$ \\
\hline Sn-113 & $115.1 \mathrm{~d}$ & Gamma & $7.09 \mathrm{E}-01$ & $6.17 \mathrm{E}-01$ & $4.30 \mathrm{E}-01$ & $2.50 \mathrm{E}-01$ & $8.20 \mathrm{E}-02$ & $1.01 \mathrm{E}-03$ & $2.07 \mathrm{E}-10$ \\
\hline $\mathrm{Sn}-117 \mathrm{~m}$ & $13.6 \mathrm{~d}$ & Gamma & $4.48 \mathrm{E}+00$ & $1.44 \mathrm{E}+00$ & $7.37 \mathrm{E}-02$ & $8.57 \mathrm{E}-04$ & $8.93 \mathrm{E}-08$ & $1.77 \mathrm{E}-23$ & $\mathrm{E}+00$ \\
\hline $\mathrm{Sn}-119 \mathrm{~m}$ & $293 d$ & Gamma & $4.79 E+00$ & $4.49 E+00$ & $3.79 \mathrm{E}+00$ & $2.94 \mathrm{E}+00$ & $1.74 \mathrm{E}+00$ & $2.20 \mathrm{E}-01$ & $1.59 \mathrm{E}-04$ \\
\hline Sn-121 & $1.13 \mathrm{~d}$ & Beta & $4.27 \mathrm{E}-02$ & $2.69 \mathrm{E}-08$ & $1,80 \mathrm{E}-24$ & $0.00 \mathrm{E}+00$ & $0.00 \mathrm{E}+00$ & $0.00 \mathrm{E}+00$ & $\mathrm{E}+00$ \\
\hline $\mathrm{Sn}-121 \mathrm{~m}$ & $55 y$ & $\mathbf{I T}$ & $3.11 \mathrm{E}-04$ & $3.11 \mathrm{E}-04$ & $3.10 \mathrm{E}-04$ & $3.09 \mathrm{E}-04$ & $3.07 \mathrm{E}-04$ & $2.98 \mathrm{E}-04$ & $2.71 \mathrm{E}-04$ \\
\hline Sn-123 & $129.2 d$ & Beta & $2.71 \mathrm{E}-01$ & $2.39 \mathrm{E}-01$ & $1.74 \mathrm{E}-01$ & $1.07 \mathrm{E}-01$ & $3.96 \mathrm{E}-02$ & $7.86 \mathrm{E}-04$ & $8.64 \mathrm{E}-10$ \\
\hline Sn-125 & $9.63 \mathrm{~d}$ & Beta/y & $1.35 \mathrm{E}+00$ & $2.58 \mathrm{E}-01$ & $3.45 \mathrm{E}-03$ & $5.35 \mathrm{E}-06$ & $8.78 \mathrm{E}-12$ & $0.00 \mathrm{E}+00$ & $0.00 \mathrm{E}+00$ \\
\hline $\mathrm{Sb}-122$ & $2.7 \mathrm{~d}$ & Beta & $5.14 \mathrm{E}-02$ & $1.40 \mathrm{E}-04$ & $2.87 \mathrm{E}-11$ & $2.66 \mathrm{E}-21$ & $0.00 \mathrm{E}+00$ & $0.00 \mathrm{E}+00$ & $0.00 \mathrm{E}+00$ \\
\hline Sb-124 & $60.2 d$ & Beta & $8.58 \mathrm{E}-03$ & $6.58 \mathrm{E}-03$ & 3.30 & $1.17 \mathrm{E}-03$ & $1.39 \mathrm{E}-04$ & $3.08 \mathrm{E}-08$ & $5.05 \mathrm{E}-21$ \\
\hline Sb-125 & $2.76 \mathrm{y}$ & Beta/y & $1.05 \mathrm{E}+00$ & $1.04 \mathrm{E}+00$ & $1.00 \mathrm{E}+00$ & $9.41 \mathrm{E}-01$ & $8.29 \mathrm{E}-01$ & $5.03 E-01$ & $8.72 \mathrm{E}-02$ \\
\hline$S b-126$ & $12.4 \mathrm{~d}$ & Beta & $2.59 \mathrm{E}-02$ & $7.16 \mathrm{E}-03$ & $2.50 \mathrm{E}-04$ & $1.63 \mathrm{E}-06$ & $5.17 \mathrm{E}-11$ & $9.41 \mathrm{E}-29$ & $0.00 \mathrm{E}+00$ \\
\hline $\mathrm{Te}-123 \mathrm{~m}$ & $119.7 \mathrm{~d}$ & IT & $1.06 \mathrm{E}-03$ & $9.28 \mathrm{E}-04$ & $6.56 \mathrm{E}-04$ & $3.89 \mathrm{E}-04$ & $1.33 E-04$ & $1.94 \mathrm{E}-06$ & $7.17 \mathrm{E}-13$ \\
\hline $\mathrm{Te}-125 \mathrm{~m}$ & $58 \mathrm{~d}$ & Gamma & $2.07 \mathrm{E}-01$ & $2.15 E-01$ & $2.25 E-01$ & $2.23 \mathrm{E}-01$ & $2.02 \mathrm{E}-01$ & $1.23 \mathrm{E}-01$ & $2.13 E-02$ \\
\hline \multicolumn{2}{|c|}{$\begin{array}{l}\text { Total photons/s/ } \\
\text { TPBAR } \\
\end{array}$} & & $1.50 \mathrm{E}+13$ & $1.05 \mathrm{E}+13$ & $6.72 \mathrm{E}+12$ & $4.44 E+12$ & $2.99 \mathrm{E}+12$ & $1.92 \mathrm{E}+12$ & +11 \\
\hline \multicolumn{2}{|l|}{$\mathrm{MeV} / \mathrm{s}$} & & $3.90 \mathrm{E}+12$ & $7.44 E+12$ & $5.56 \mathrm{E}+12$ & $4.12 \mathrm{E}+12$ & $3.06 \mathrm{E}+12$ & $2.08 \mathrm{E}+12$ & $8.05 E+11$ \\
\hline \multicolumn{2}{|c|}{$\begin{array}{l}\text { Decay Heat, } \\
\text { watts/TPBAR }\end{array}$} & & 2.12 & 1.70 & 1.34 & 1.08 & 0.88 & 0.68 & 0.36 \\
\hline \multicolumn{2}{|c|}{$\begin{array}{l}\text { Decay Heat, } \\
\text { watts/charge* }\end{array}$} & & 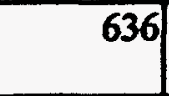 & 50 & 700 & ן דא & 264 & 204 & 100 \\
\hline
\end{tabular}

* Assume 300 rods (full-length basis) in each furnace charge/basket $\mathbf{I T}=$ Icomeric transition 


\section{B6a. TPBAR Baseplates}

Type: Intermediate-level Waste.

Description: TPBARs placed in the CLWR for irradiation are bundled in assemblies consisting of TPBARs secured to baseplates. The baseplates serve to facilitate handling of the TPBAR bundles into the reactor and do not contain tritium-producing target material. Per Ref. 24, the typical Westinghouse PWR baseplate includes the hold-down assembly and the 16 thimble plugs. The hold-down assembly is approximately $21.6 \mathrm{~cm}\left(8.5\right.$ ") square and $12.7 \mathrm{~cm}\left(5^{\prime \prime}\right)$ high. The thimble plugs are $15-18 \mathrm{~cm}$ long with an overall assembly height of $28-31 \mathrm{~cm}$. The entire assembly weighs about $4.1 \mathrm{~kg}$. (9.1 lb.) The baseplate materials become activated in the reactor and may pick up crud deposits. The primary driver for the radioactive source term is Co-60. The average cobalt concentration is estimated to be $122,000 \mathrm{Ci} / \mathrm{m}^{3}$, leading to an estimated radiation level of $50 \mathrm{rem} / \mathrm{hr}$ at 1 meter or $2 \mathrm{rem} / \mathrm{hr}$ at 5 meters from the hold-down assembly. Other radionuclides of interest for the LTA hold-down assembly are shown in table below. This source term will vary between baseplates and will be somewhat dependent on tye reactor used. Therefore, this data is considered preliminary at this time. The TPBARs will be removed from the baseplates at the Reactor Utility prior to shipment to SRS for furnace extraction.

Order of Magnitude Radionuclide Distribution for LTA Hold-down Assembly

\begin{tabular}{|c|r|r|}
\hline Radionuclide & Inventory (Ci) & Concentration (Ci/m ${ }^{3}$ ) \\
\hline Radionuclides Important & to Waste Classification & 19 \\
\hline $\mathrm{C}-14$ & 0.01 & 86 \\
\hline $\mathrm{Ni}-59$ & 0.04 & 9400 \\
\hline $\mathrm{Ni}-63$ & 4.9 & 0.2 \\
\hline $\mathrm{Nb}-94$ & 0.0001 & 0.05 \\
\hline Tc-99 & 0.00003 & \\
\hline Radionuclides Important & to Dose Rate & 122,000 \\
\hline Co-60 & 63 & \\
\hline
\end{tabular}

Generation: Irradiated baseplates will be cut from the TPBAR assemblies at the Reactor Utility, packaged, and shipped to SRS for disposal.

Handling and Packaging: Waste must be surveyed for gamma radiation field and packaged to meet the handling requirements at the CLWR-TEF and at the waste disposal facility. 
Annual Ouantities:

\begin{tabular}{|l|l|c|r|l|}
\hline & & Waste Destination & & \\
\hline $175 \mathrm{ft}^{3}$ & $5,000 \mathrm{lb}$ & ILTV Silos & $5 \mathrm{~m}^{3}$ & $2,270 \mathrm{~kg}$ \\
\hline
\end{tabular}

(a) Assume one baseplate per 16-rod bundle, or $\sim 250$ baseplates.

(b) Assume 50 baseplates per IITV silo $\Rightarrow$ need 5 silos or $5 \times 35=175 \mathrm{ft}^{3}$.

(c) Assume $10 \mathrm{lb}$. per baseplate; 250 baseplates $\Rightarrow 2,500 \mathrm{lb}$.

(d) Assume each baseplate waste container is same as TPBAR basket and is made from 12" schedule $10 \mathrm{~S}$ steel pipe $(24.2 \mathrm{lb}$. / ft), each $\sim 16$ feet long $\Rightarrow 450 \mathrm{lb}$./container, include 75 lb. for a container plug.

(e) For 5 waste containers $\Rightarrow 2,250 \mathrm{lb}$.

(f) Assume no overpack needed for baseplates.

(g) Total containerized waste weight $=4,750 \mathrm{lb}$. Round off to $5,000 \mathrm{lb}$.

Waste Minimization:

(a) There is no feasible alternative to the use of baseplates.

(b) Volume reduction may allow more than 50 baseplates to be put in each ILTV silo.

\section{Treatment Options:}

None required.

\section{Comment:}

Current plans are for the CLWR Utility to remove the baseplates from the TPBARs, and to package them for disposal'at SRS. 


\section{B7. Failed Furnace Components (Extraction)}

Type: Intermediate-level Waste.

Description: Furnace cover, heaters and gaskets.

Generation: Furnace heaters will burn out. Baskets and furnace covers may experience structural failure. Furnace cover gaskets are replaced for each furnace charge.

Handling and Packaging: Waste must be surveyed for radiation and packaged to meet the handling requirements of the EAV Intermediate Level Tritium Vaults. A shipping cask will need to be developed for transporting failed components to Solid Waste Management.

Annual Quantities:

\begin{tabular}{|c|c|c|c|c|}
\hline & & Waste Destination & & \\
\hline $90 \mathrm{ft}^{3}$ & $7,500 \mathrm{lb}$ & IITV Bulk Cell & $2.5 \mathrm{~m}^{3}$ & $3,400 \mathrm{~kg}$ \\
\hline
\end{tabular}

(a) Assume two B-12 containers per year to ILTV Bulk Cell $\Rightarrow 90 \mathrm{ft}^{3}$

(b) Assume $75 \%$ void space, 50 vol \% aluminum (2.7 SpG), 50 vol \% stainless steel (8.0 $\mathrm{SpG}) \Rightarrow 90 \times 0.25 \times 62.3 \times(0.5 \times 2.7+0.5 \times 8) \sim 7,430 \mathrm{lb}$.

Waste Minimization:

There is no feasible alternative to the use of electrically heated furnaces.

Treatment Options:

Volume reduction, followed by packaging for disposal in EAV Intermediate Level Vaults.

Comment:

None. 


\section{B7a. Nonhazardous Process Equipment (Extraction)}

Type: Intermediate-level Waste, Low-level Radioactive Waste

Description: This waste stream consists of discarded process equipment or parts. Equipment may include vessels, tanks, pressure gauges, valves and fittings which provided primary tritium containment, as well as pneumatic cutters, video cameras, cranes and confinement box parts. Minor maintenance parts (e.g., small gaskets, bolts) are managed as Job Control Waste. All process equipment is considered to be non-incinerable and non-compactible due to physical form and potential tritium offgassing.

Generation: Nonhazardous Process Equipment (Extraction) waste is generated by preventative and corrective maintenance of the tritium furnace extraction systems, or by replacement of containment devices in the extraction process. Due to the potential for highly radioactive gamma emitters, some waste may be too hot to be disposed of in the LAW vaults.

Handling and Packaging: Following removal from process, process equipment may be stored in engineered hoods to control offgassing tritium within monitored ventilation system. Management will review tritium offgassing rate, radiation emission and facility conditions to determine when to dispose of process equipment. Equipment pieces are wrapped in plastic bags (heavy duty polyurethane). Following a period of off-gassing and/or decay, the plastic-wrapped equipment will be placed into pre-approved containers (B-12, B-25, 55 gallon drums, 5 gallon containers, etc.) for transport to the E-Area Vaults.

\section{Annual Ouantities:}

\begin{tabular}{|c|c|c|c|c|}
\hline & & Waste Destination & & \\
\hline $90 \mathrm{ft}^{3}$ & $7,500 \mathrm{lb}$ & LAW Vaults & $2.5 \mathrm{~m}^{3}$ & $3,400 \mathrm{~kg}$ \\
\hline $90 \mathrm{ft}^{3}$ & $7,500 \mathrm{lb}$ & ILTV Bulk Cell & $2.5 \mathrm{~m}^{3}$ & $3,400 \mathrm{~kg}$ \\
\hline
\end{tabular}

(a) Assume two B-12 containers per year to LAW Veults $\Rightarrow 90 \mathrm{ft}^{3}$.

(b) Assume two B-12 containers per year to ILTV Bulk Cell $\Rightarrow 90 \mathrm{ft}^{3}$

(c) Assume $75 \%$ void space, $50 \mathrm{vol} \%$ aluminum (2.7 SpG), 50 vol \% stainless steel (8.0 $\mathrm{SpG}) \Rightarrow 90 \times 0.25 \times 62.3 \times(0.5 \times 2.7+0.5 \times 8) \sim 7,430 \mathrm{lb}$.

Waste Minimization:

(a) Extend process equipment life through preventive maintenance.

(b) Decontaminate equipment and recycle metal. 


\section{Treatment Options:}

Store until acceptable decay rates are achieved.

\section{Comments:}

Radioactive contaminants will have the same distributions as spent TPBARs and crud. 


\section{B8. HEPA Filters (Extraction)}

Type: Low-level Radioactive Waste or Intermediate-level Waste.

Description: High-efficiency particulate air (HEPA) filters are filters capable of trapping and retaining at least 99.97 percent of all monodispersed particles $\geq 0.3 \mu \mathrm{m}$ in diameter. HEPA filters are generally made of a variety of paper and metallic materials.

Generation: Extraction furnace gases and stack gases are passed through HEPA filters, and the filters require regular replacement.

Annual Quantities: Minimal.

Waste Minimization:

A reusable HEPA filter is being developed.

\section{Treatment Options:}

Not applicable if reusable filters are used. Treatment for a conventional HEPA filter is a function of its composition; i.e., whether it is largely paper (thermal treatment) or metal (compaction). Since CLWR-TEF HEPA filters are assumed to be constructed of nonhazardous materials, they will be characterized and packaged for disposal, as appropriate.

\section{Comments:}

(a) HEPA filters will not prevent the release of tritium to the atmosphere. However, HEPA filters may be used to remove particulates which may contain tritium contamination.

(b) Carbon filters may be used in conjunction with HEPA filters to remove organics from stack gases. However, this would introduce an additional waste of spent carbon beds. 


\section{B9. Mixed Waste Process Equipment}

\section{Type: Mixed Low-level Waste}

Description: See Waste Stream B5. One potential mixed waste process equipment identified so far is the palladium-silver diffuser. Palladium-silver diffusers currently in use at SRS are about two feet long and one foot in diameter. Silver is a hazardous material with RCRA code D011. During use the diffusers will become contaminated with tritium.

Generation: The CLWR-TEF currently does not have any plans to install diffusers, which are to be installed in 233-H under the TFM \& C Project to support processing CLWR-TEF furnace gas. Thus this waste stream is stated here for information only and in case a change is made to the Facility. Existing tritium processing at SRS uses palladium-silver alloy diffusers to separate hydrogen isotopes from He-3 and $\mathrm{He}-4$ after target rods are melted in crucibles to release the trapped gases. A similar CLWR-TEF system will need two diffusers. Experience at SRS is that the diffusers must be replace after two or three years of service.

Mixed Process Equipment waste is generated by preventative and corrective maintenance of the extraction and post-extraction tritium processing systems which contain RCRA metals $(\mathrm{Hg}, \mathrm{Cd}$, $\mathrm{Ag}, \mathrm{Pb}$, etc.) or weld, or by replacement of $\mathrm{Pd}-\mathrm{Ag}$ Diffusers. Historical equipment such as tritium product containers may contain mercury contamination and require treatment as mixed waste.

Annual Quantities:

\begin{tabular}{|l|r|c|r|r|}
\hline & & Waste Destination & & \\
\hline $0.3 \mathrm{ft}^{3}$ & $50 \mathrm{lb}$ & $\begin{array}{c}\text { Pd-Ag Diffusers to } \\
\text { Interim Storage/Off-site }\end{array}$ & $0.01 \mathrm{~m}^{3}$ & $23 \mathrm{~kg}$ \\
\hline
\end{tabular}

(a) Assume one Pd-Ag diffuser every 5 years.

(b) Assume each diffuser is 12 in $0 . D . \times 2$ feet long $\Rightarrow 1.6 \mathrm{ft}^{3}$.

(c) Assume, for shell container, $12^{\text {" }}$ schedule 10 steel pipe $(24.2 \mathrm{lb} / \mathrm{ft}) \Rightarrow 48.4 \mathrm{lb}$.

(d) Assume, for tubes, $75 \%$ void, steel $(\mathrm{SpG}=8) \Rightarrow 200 \mathrm{lb}$.

(d) Divide unit weight $(-250 \mathrm{lb})$ and volume by 5 to obtain annual generation rates.

Handling and Packaging: Following removal from process and glovebox, waste equipment is stored in engineered air hoods to control offgassing tritium within a monitored ventilation system. Management will review offgassing rate and facility conditions to determine when to dispose of process equipment. Waste equipment pieces are wrapped in plastic bags (heavy duty polyurethane). Following a period of off-gassing, the plastic-wrapped equipment will be placed 
into pre-approved containers (B-12, B-25, 55 gallon drums, 5 gallon containers, etc.) for transport to the Mixed Waste Storage pads or buildings.

Waste Minimization:

(a) Remove dirt from the tritium extraction and processing lines to prolong diffuser lifetime.

(b) Improve manufacturing methods or diffuser design to eliminate current diffuser brazing failures.

(c) Extend process equipment life by controlling process gas oxygen and water vapor limits.

(d) Extend process equipment life though preventive maintenance.

(e) Decontaminate equipment/recycle metal.

\section{Treatment Options:}

(a) Macroencapsulation prior to packaging for storage and/or disposal.

(b) Thermal desorption to remove as much tritium as practical.

(c) For hydride beds, use isotopic exchange following thermal desorption. Passivate hydride beds with compressed oxygen or air.

\section{Comments:}

(a) Failure of diffusers has been attributed to manufacturer brazing problems or to dirt in the current tritium processing lines. In a clean facility diffusers should last longer, but there is no experience to prove that. The hydrogen passing through the palladium will eventually cause embrittlement and swelling and will result in change-out even if current problems with brazing are resolved. Oxygen and water vapor can attack Pd-Ag diffusers, causing intergranular failure.

(b) Chromium in stainless steel, Inconel or zircaloy is assumed to pass the TCLP tests, due to the high corrosion resistance of these materials.

(c) TCLP testing of Pd-Ag diffusers may allow this waste to be managed as low-level waste. 


\section{B10. Mixed and Hazardous Waste OiWSolvent}

Type: Mixed Low-Level Waste, Hazardous Waste.

Description: Lubricating oil and solvents used for decontamination, cleaning, degreasing, spill clean-up and various maintenance activities may contain RCRA hazardous or listed components. Contamination with tritium and/or other radioactive components produces a mixed waste.

Lubrication oil is used in vacuum pumps, blowers, robotic equipment, and vehicles operated in process buildings. Due to bearing wear or the tendency of oil to accumulate organic contaminants, waste oils have been found to contain the following RCRA codes: D005, D006, D008, D009, D018, F001, F003, F004, and F005. If falling mercury drop pumps or mercury diffusion pumps are used, mercury contamination (D009) will be present. Past experience at SRS has shown pump oil associated with tritium facilities can have tritium activity levels ranging from background to $185 \mathrm{Ci}$. Residues of solutions used for decontamination, cleaning, or degreasing during equipment maintenance or repair may also be mixed waste. The solvents may be inherently hazardous and/or may become contaminated with radioactive or hazardous materials during the cleaning process.

Generation: Routine analytical, process operation, maintenance, cleaning, degreasing, and decontamination activities.

Handling and Packaging: Segregate and store in a Satellite Accumulation Area per RCRA requirements (40CFR262.34(c)).

Annual Quantities: Minimal.

Waste Minimization:

(a) Product substitution, to eliminate RCRA hazardous solvents.

(b) Change to mechanical/physical stripping/cleaning devices to avoid solvent use.

(c) Use of fluidless, all-metal pumps (e.g. Nometex) for tritium pumping.

(d) Use of oil-free blowers for discharges to stacks.

(e) Use of cooling system pumps that are water-cooled and lubricated.

Treatment Options:

(a) Incineration at CIF, followed by stabilization or vitrification of ash. 
(b) Stabilization. Considering that the annual volume estimate is small, just stabilization may be more practical.

Hazardous Waste:

(a) Energy recovery at the SRS power house, if halogen compounds are within allowable limits.

(b) Ship to a DOE-approved commercial treatment and disposal facility.

\section{Comments:}

(a) Used oil is regulated as a hazardous waste in the State of California.

(b) Current environmental regulations make it advantageous to avoid the generation of mixed waste. Use of nonhazardous oils for equipment and nonhazardous cleaning agents is highly advisable. For example, a new, nonhazardous and environmentally safe solvent for cleaning metal surfaces is available through Organitec, a Tennessee-based company.

(c) While thermal desorption of volatile organics may convert a mixed waste to a low-level waste, if the off-gases are adsorbed on activated carbon, the spent carbon bed becomes a secondary waste stream.

(d) Fluidless Nometex pumps are being used for certain applications n 233-H, replacing mercury diffusion pumps and Sprengel falling mercury drop pumps used in the past in 234-H. Double containment bellow-sealed pumps and fluidless, all-metal scroll pumps are viable candidates. However, these pumps are sensitive to particulate, chemical, and mercury attack, so the process lines must be kept very clean.

(e) With the exception of compressors, 233-H tritium process pumps do not use mercury or organic lubricants. 


\section{B11. Mixed Waste Solvent Rags}

Type: Mixed Low-level Waste.

Description: Rags or paper products (such as Kim-Wipes) that have been impregnated with solutions used for decontamination, cleaning, degreasing, spill clean-up and various maintenance activities. The solutions may contain hazardous components such as Freon or methanol and/or may also become contaminated with radioactive or hazardous components wiped from the object being cleaned.

Generation: Routine maintenance, cleaning, degreasing, and decontamination activities.

Handling and Packaging: Handled and packaged similarly to job control waste. Waste items are placed in plastic bags and 21 " $\times 21$ " $\times 21^{\prime \prime}$ cardboard boxes. The outside of the plastic bags are smeared for contamination and sniffed for detectable tritium offgassing of $4 \mathrm{E}-5 \mu \mathrm{Ci} / \mathrm{cc}$.

Annual Ouantities: Minimal.

Waste Minimization:

(a) Product substitution, to eliminate RCRA hazardous solvents (e.g., Freon, methanol).

(b) Change to mechanical/physical stripping/cleaning devices to avoid solvent use.

Treatment Options:

(a) Thermal desorption followed by compaction for storage and/or disposal.

(b) Incineration at CIF, followed by stabilization or vitrification of ash.

Comments:

(a) Current environmental regulations make it advantageous to avoid the generation of mixed waste. Use of nonhazardous cleaning agents is advisable when the solvent rags will come in contact with radioactive materials. Commercially available rags impregnated with a decontamination solution (brand name Maslin Wipes) have been tested by Sandia National Laboratories - New Mexico for hazardous components and have been found to be nonhazardous.

(b) While thermal desorption of volatile organics may convert a mixed waste to a low-level waste, if the off-gas is absorbed on activated carbon, the spent carbon bed becomes a secondary waste stream. 


\section{B12. Analytical Laboratory/Rad Con Chemicals}

Type: Hazardous, or Mixed Low-level Waste.

Description: Used, excess, or out-of-date chemicals used by Analytical Laboratories and Rad Con in Tritium. The chemicals identified in this waste stream are considered hazardous and may be solids, liquids, or gels. Gas standards and other pressurized gases are excluded. A variety of hazardous waste codes are possible.

Generation: Routine analytical chemistry and radiological control procedures needed to support operations of the CLWR-TEF. Used chemicals are hazardous and may become a mixed waste, if used in a tritium-contaminated environment. These chemicals are used by Analytical Lab and Rad Con and reported in the draft 1996 Tier II Hazardous Chemical Inventory Report (source: R. A. Rhodes, Tritium Chemical Coordinator).

\section{Annual Quantities:}

Since consumption of these chemicals will result in discharges to the Effluent Treatment Facility, building HVAC, job control waste, tritiated oil, etc., the projected quantities below are considered to be reflected and included in the other waste streams. One chemical, Opti-Fluor, constitutes more than $75 \%$ by weight and results are reported with and without it.

\begin{tabular}{|r|r|c|r|r|}
\hline $45 \mathrm{ft}^{3}$ & $2,762 \mathrm{lb}$ & Total & $1.3 \mathrm{~m}^{3}$ & $1,256 \mathrm{~kg}$ \\
\hline $10 \mathrm{ft}^{3}$ & $644 \mathrm{lb}$ & Excluding Opti-Fluor & $0.3 \mathrm{~m}^{3}$ & $293 \mathrm{~kg}$ \\
\hline
\end{tabular}

(a) Annual usage estimated based on 4x average inventory. See Table B3 for distribution.

(b) Assumed an average $\mathrm{SpG}=1$, or $62.3 \mathrm{lb} / \mathrm{tt}^{3}$.

\section{Waste Minimization:}

(a) Use micro-analytical equipment to minimize chemical usage.

(b) Buy only require amounts to minimize disposal of expired excess chemicals; recycle unused chemicals.

\section{Treatment Options:}

Will be a function of the type of chemical; e.g., solid, liquid, acid, base, etc.

Comments: None. 
Table B3

Tritium Analytical Laboratory/Rad Con Tier II Hazardous Chemical Inventory (10/96)

\begin{tabular}{|c|c|c|c|c|}
\hline Chemical & Manufacturer & $\begin{array}{c}\text { Average } \\
\text { Inventory } \\
\text { lb }\end{array}$ & $\begin{array}{c}\text { Maximum } \\
\text { Inventory } \\
\text { lb }\end{array}$ & $\begin{array}{c}\text { Estimated } \\
\text { Usage* } \\
\text { Ib/yr }\end{array}$ \\
\hline ABC Dry Chemical & Amerex & 10 & 10 & 40.0 \\
\hline Aero Clearview Glass Cleaner & ABC Compounding & 2.4 & 2.4 & 9.6 \\
\hline Aero Ammoniated Glass Cleaner & ABC Compounding & 0.7 & 0.75 & 3.0 \\
\hline Aero Lemonair Air Freshner & ABC Compounding & 0.65 & 0.7 & 2.6 \\
\hline Alconox & Alconox & 2 & 4 & 8.0 \\
\hline $\begin{array}{l}\text { All Pro AP210 Lemon Yellow Spray } \\
\text { Paint }\end{array}$ & Major Paint & 0.75 & 0.75 & 3.0 \\
\hline All Pro AP230 Orange Spray Paint & Major Paint & 0.75 & 0.75 & 3.0 \\
\hline Apiezon Products & James E. Biddle & 4.4 & 4.4 & 17.6 \\
\hline Ax-It-Plus Stripper & Betco & 3.0 & 3.0 & 12.0 \\
\hline Brillo Soap Pads & Purex Industrial & 1 & 1 & 4.0 \\
\hline Comet Cleanser & Proctor \& Gamble & 2 & 2 & 8.0 \\
\hline CRC 3-36 Aerosol & CRC Industries & 1 & 1 & 4.0 \\
\hline Dow Corning Multi-purpose Sealant & Dow Corning & 1 & 1 & 4.0 \\
\hline Dow Coming High Vacuum Grease & Dow Corning & 1.6 & 1.6 & 6.4 \\
\hline Duo-seal Vacuum Pump Oil & $\begin{array}{l}\text { Welch Vacuum } \\
\text { Technology }\end{array}$ & 2.0 & 2.0 & 8.0 \\
\hline Easy-off Oven Cleaner & Reckitt \& Coleman & 1.2 & 1.2 & 4.8 \\
\hline Enviro-Tech Precision Dusting & Tech Spray & 7.5 & 7.5 & 30.0 \\
\hline Ethanol USP-190 proof & $\begin{array}{l}\text { AAPER Alcohol \& } \\
\text { Chemical }\end{array}$ & 4.8 & 5.0 & 19.2 \\
\hline Ethylene Glycol & Mallinckrodt & 0.1 & 0.1 & 0.4 \\
\hline Inlet 19 Vacuum Pump Oil & $\begin{array}{l}\text { Inland Vacuum } \\
\text { Industries } \\
\end{array}$ & 20.0 & 20.2 & 80.0 \\
\hline Isoclean Concentration & Isolab & 2.2 & 2.2 & 8.8 \\
\hline Joy Liquid Dishwashing Detergent & Proctor \& Gamble & 1 & 1 & 4.0 \\
\hline Kimwipes lens cleaning solution & Kimberly-Clark & 1.75 & 1.75 & 7.0 \\
\hline Leak-Tec 277C & $\begin{array}{l}\text { American gas \& } \\
\text { Chemical }\end{array}$ & 1.3 & 1.35 & 5.2 \\
\hline Mechanical Pump Oil 15 & $\begin{array}{l}\text { Edwards High } \\
\text { Vacuum }\end{array}$ & 7.3 & 7.4 & 29.2 \\
\hline
\end{tabular}

"Estimated annual usage based on $4 x$ average inventory. 


\section{Table B3 (Cont'd)}

Tritium Analytical Laboratory/Rad Con Tier II Hazardous Chemical Inventory (10/96)

\begin{tabular}{|l|l|r|r|r|}
\hline \multicolumn{1}{|c|}{ Chemical } & \multicolumn{1}{|c|}{ Manufacturer } & \multicolumn{1}{|c|}{$\begin{array}{c}\text { Average } \\
\text { Inventory } \\
\text { lb }\end{array}$} & $\begin{array}{l}\text { Maximum } \\
\text { Inventory } \\
\text { lb }\end{array}$ & $\begin{array}{c}\text { Estimated } \\
\text { Usage* } \\
\text { lb/yr }\end{array}$ \\
\hline Mercury Spill Clean-up Kit & JT Baker & 2.5 & 2.5 & 10.0 \\
\hline $\begin{array}{l}\text { Met-L-X Dry Powder Extinguisher } \\
\text { Agent }\end{array}$ & $\begin{array}{l}\text { Ansul Fire } \\
\text { Protection }\end{array}$ & 53.7 & 53.7 & 214.8 \\
\hline Mighty X Wax Stripper & AMREP & 1.4 & 1.5 & 5.6 \\
\hline NoKoRude Soldering Paste & M.W. Dunton & 1.0 & 1.0 & 4.0 \\
\hline Opti-Fluor & Packard Instruments & 529.4 & 532.4 & 2117.6 \\
\hline RTV128 Silicone Rubber Sealant & General Electric & 0.2 & 0.2 & 0.8 \\
\hline $\begin{array}{l}\text { Rustmaster Spray Enamel OSHA } \\
\text { Orange }\end{array}$ & Glidden & 0.7 & 0.75 & 2.8 \\
\hline Santovac 5 Vacuum Pump Fluid & Monsanto & 0.25 & 0.3 & 1.0 \\
\hline Septisol Solution & Calgon Vestal Lab & 2.0 & 2.1 & 8.0 \\
\hline Sodium Hydroxide Solid & EM Science & 1.1 & 1.1 & 4.4 \\
\hline Superacrylic Spray Enamel & Sherwin Williams & 0.5 & 0.5 & 2.0 \\
\hline Trichlorofluoroethane & Allied Signal & 1.0 & 1.0 & 4.0 \\
\hline WBBM 55 Shredder Oil & Whitaker Brothers & 16.3 & 17.5 & 65.2 \\
\hline
\end{tabular}

Estimated annual usage based on $4 \mathrm{x}$ average inventory. 


\section{B13. Nonhazardous Tritiated Oil}

Type: Radioactive Liquid Waste, Low-level Radioactive Waste.

Description: Lubricating oil in pumps and other mechanical systems may become contaminated with varying amounts tritium.

Generation: Waste oil is generated by preventative maintenance of oil pumps or compressors, chillers and gear boxes in tritium-processing systems.

Handling and Packaging: Most tritiated oil contains tritium oxide and should be handled accordingly. Radioactive, nonhazardous waste oil is stored in Radiological Material Areas (RMAs) in small carboys (plastic containers) in secondary containment. Later the oil will be consolidated in 13-gallon carboy. Once the carboy is filed, a representative sample is taken for analysis. Determine acceptability of the oil for the SRS Power House (tritium activity limit 2000 $\mathrm{pCi} / \mathrm{ml}$ ) or the CIF (tritium activity limit 3,417 nCi/g). Package the waste oil/fluid for transportation to the Power House or CIF, using an absorbent in the overpack to capture any liquid spills.

\section{Annual Quantities:}

\begin{tabular}{|r|r|c|r|r|}
\hline & & Waste Destination & & \\
\hline $6.5 \mathrm{ft}^{3}$ & $400 \mathrm{lb}$ & $\begin{array}{c}\text { Liquid form to Power } \\
\text { House/CIF }\end{array}$ & $0.2 \mathrm{~m}^{3}$ & $180 \mathrm{~kg}$ \\
\hline $13 \mathrm{ft}^{3}$ & $800 \mathrm{lb}$ & $\begin{array}{c}\text { Stabilized waste form to } \\
\text { LAW Vaults }\end{array}$ & $0.4 \mathrm{~m}^{3}$ & $360 \mathrm{~kg}$ \\
\hline
\end{tabular}

(a) Assume 100 gallons/yr, $50 \%$ to CIF and $50 \%$ need to be stabilized.

(b) Assume 50 gallons/yr stabilize to $2 \mathrm{x}$ volume.

(c) Assume $\mathrm{SpG}=1$ or $62.3 \mathrm{lb} / \mathrm{ft}^{3}$ for weight calculations, for both liquid and stabilized waste form.

Waste Minimization:

Use oil-less or low oil inventory pumps and equipment.

Treatment Options:

(a) Energy recovery at the SRS Power House. 
(b) Nonhazardous tritiated waste oil with tritium concentration meeting CIF WAC will be incinerated at the CIF.

(c) Stabilize and dispose in the EAV LAW Vaults.

Comments:

None. 


\section{B13a. Glovebox Bubbler Fluid}

Type: Radioactive Liquid Waste, Low-level Radioactive Waste.

Description: Glovebox bubblers contain a viscous liquid such as glycol or a silicone fluid. They are used as glovebox overpressure relief devices and also act as traps for removing contaminants from exiting glovebox atmosphere gases. The liquid in the bubblers is susceptible to tritium contamination. The liquids used in $233-\mathbf{H}$ glovebox bubblers are not currently regulated under RCRA as hazardous waste.

Generation: Bubblers are used as resealing pressure relief valves for gloveboxes. In the event of excessive glovebox pressure, gases will discharge through the bubblers rather than cause physical damage to the glovebox. Tritium in the glovebox atmosphere will readily exchange with the hydrogen atoms in the bubbler liquid. Tritium gloveboxes are normally maintained at a negative pressure relative to the room and tritium levels in the boxes are kept low. Therefore, little tritium activity should accumulate in the bubblers unless an overpressure occurs. Bubbler fluid in the extraction area may become contaminated with gamma emitting radionuclides.

Handling and Packaging: See Waste Stream B13.

Annual Quantities:

\begin{tabular}{|c|r|c|r|r|}
\hline & & Waste Destination & & \\
\hline $0.07 \mathrm{ft}^{3}$ & $4 \mathrm{lb}$ & Liquid form to Off-site & $0.002 \mathrm{~m}^{3}$ & $1.8 \mathrm{~kg}$ \\
\hline $0.13 \mathrm{ft}^{3}$ & $8 \mathrm{lb}$ & $\begin{array}{c}\text { Stabilized waste form to } \\
\text { LAW Vaults }\end{array}$ & $0.004 \mathrm{~m}^{3}$ & $3.6 \mathrm{~kg}$ \\
\hline
\end{tabular}

(a) Assume 1 gallon/yr, 50\% to Off-site and $50 \%$ need to be stabilized.

(b) Assume 0.5 gallons/yr stabilize to $2 x$ volume.

(c) Assume $\mathrm{SpG}=1$ or $62.3 \mathrm{lb} / \mathrm{ft}^{3}$ for weight calculations, for both liquid and stabilized waste form.

Waste Minimization:

There is no feasible substitute for using bubblers as glovebox pressure relief valves. 


\section{Treatment Options:}

(a) Stabilize bubbler liquid in an absorbent and send to EAV LAW Vaults for disposal..

(b) If tritium and halogen levels are acceptable, send to DDSI or SRS Power House for energy recovery or to SEG/CIF for incineration.

\section{Comments:}

(a) Mound Laboratory uses glycol in their bubblers; SRS uses a more expensive silicone fluid.

(b) Consider changing to glycol for cost effectiveness and disposability. 


\section{B14. Tritiated Water and Aqueous Solutions}

Type: Radioactive Liquid Waste.

Description: Water contaminated with very dilute amounts $(<20,000 \mathrm{pCi} /)$ of tritiated water (tritium oxide). Other radionuclides with characteristics of the TPBAR crud and TPBAR may also be present.

Generation: 1) Tritium contamination of process cooling water; 2) TPBAR cask/trailer decon solution; 3) Aqueous Analytical Lab/Rad Con counting cocktails.

Handling and Packaging: Sample for acceptability to send to the Effluent Treatment Facility (ETF), Scientific Ecology Group (SEG) in Tennesssee,.or stabilize.

Annual Quantities:

\begin{tabular}{|r|r|c|r|r|}
\hline & & Waste Destination & & \\
\hline $1,340 \mathrm{ft}^{3}$ & $83,500 \mathrm{lb}$ & $\begin{array}{c}\text { Cask/Trailer Decon wash } \\
\text { to ETF }\end{array}$ & $38 \mathrm{~m}^{3}$ & $38,000 \mathrm{~kg}$ \\
\hline $134 \mathrm{ft}^{3}$ & $8,350 \mathrm{lb}$ & All other sources to ETF & $3.8 \mathrm{~m}^{3}$ & $3,800 \mathrm{~kg}$ \\
\hline
\end{tabular}

(a) Assume 1000 gallons per cask/trailer decon and 1000 gallons per year all other sources.

(b) Assume 10 truck shipments/yr, or $10 \mathrm{cask} /$ trailer decon washes/yr.

Waste Minimization:

(a) A water/solvent decon wash is assumed for shipping cask/trailer per current practice. Alternative water-less cask decon techniques may be investigated.

(b) Design equipment with water cooling to ensure/eliminate migration of tritium to cooling water.

Treatment Options:

(a) For trace tritium levels acceptable to the Effluent Treatment Facility (ETF), send to ETF for processing. Current experience indicates that Analytical Lab/Rad Con counting cocktails may be discharged to the ETF.

(b) For tritium levels acceptable to Scientific Ecology Group (SEG), less than $3.0 \times 10^{-3}$ $\mu \mathrm{Ci} / \mathrm{cc}$, send to SEG for incineration. 
(c) Stabilize by absorbing on Aquaset/zeolite and send to the EAV LAW Vaults for disposal.

(d) Use Z-Bed Recovery System to process and recover highly tritiated water.

Comments:

Free liquid cannot be disposed of in the EAV. 


\section{B15. Teledyne Oxygen Sensor Micro-Fuel Cells}

Type: Mixed Low-level Waste, Hazardous Waste.

Description: Micro-fuel cells used in the Teledyne oxygen sensors are sealed in a cell which contains lead (D008). The sensors are used in both clean and tritium-contaminated environments.

Generation: Spent fuel cells from Teledyne oxygen sensors used in tritiated environments become a mixed waste. Defective unused fuel cells or spent fuel cells from Teledyne sensors in clean areas will be a hazardous waste.

Handling and Packaging: Store in a Satellite Area per RCRA requirements (40CFR262.34 (c)). Annual Ouantities:

\begin{tabular}{|l|r|c|c|r|}
\hline & & Waste Destination & & \\
\hline $0.13 \mathrm{ft}^{3}$ & $10 \mathrm{lb}$ & Hazardous to Off-site & $0.004 \mathrm{~m}^{3}$ & $4.5 \mathrm{~kg}$ \\
\hline $0.13 \mathrm{ft}^{3}$ & $15 \mathrm{lb}$ & Mixed to Off-site/Storage & $0.004 \mathrm{~m}^{3}$ & $6.8 \mathrm{~kg}$ \\
\hline
\end{tabular}

(a) Assume 10 spent cells per year in clean areas and 10 spent cells per year in tritiumcontaminated area.

(b) Assume clean spent cells shipped to off-site vendor in 1 gallon container.

- Assume 1 gallon containerized waste weighs $5 \mathrm{lb}$.

(d) Assume mixed cells macroencapsulated in 1 gallon container for off-site vendor or storage.

(e) Assume macroencapsulated waste form results in $50 \%$ weight increase.

Waste Minimization:

Product substitution to eliminate RCRA hazardous lead.

Treatment Options:

Hazardous Waste: Ship to a DOE-approved commercial treatment and disposal facility.

Mixed Waste: Macroencapsulation followed by disposal in a RCRA Subtitle C facility. 
Comments:

Current environmental regulations make it advantageous to avoid the generation of mixed waste. Use of a nonhazardous, non-lead substitute product appears to be the most practical solution. 


\section{B16. Palladium/Electrolysis Membrane}

Type: Low-level Radioactive Waste.

Description: Palladium membranes are used to separate impurity gases from hydrogen isotopes, without generating water. A palladium membrane reactor can also be used to recover tritium or hydrogen from waters or hydrogen oxides. Similarly, electrolysis is a technology that can be used for recovering elemental hydrogen isotopes from water vapors, without generating spent $\mathrm{Mg}$ or $\mathrm{U}$ bed waste. Waste palladium reactor/electrolysis membranes will be contaminated with tritium.

Generation: Equipment failure or replacement of failed parts/modules. This waste stream will only be generated if either the palladium membrane reactor or the solid oxide electrolysis technology is adopted to replace Z-bed recovery using a $\mathrm{Mg}$ bed or a $U$ bed. These technologies were evaluated and not adopted for the CLWR-TEF at this time. Thus this waste stream is not anticipated to be generated per current CLWR-TEF process fowsheet. It is included here for information and in case there is a change in the baseline $Z$ bed recovery technology.

Annual Quantities: None at this time.

Waste Minimization:

(a) Modular design to isolate potential failure elements, to avoid changing out the entire unit.

(b) Palladium membrane reactor and solid oxide electrolysis equipment should avoid use of RCRA metals in their construction.

Treatment Options:

Package for disposal in E-Area LAW Vaults.

Comments:

None. 


\section{B17. Ion Exchange Resin Beds}

Type: Low-level Radioactive Waste.

Description: Spent containerized ion exchange resin used to purify water coolant in the irradiated TPBAR storage basin. Radioactivity is present in the coolant from the TPBAR crud and pieces of irradiated TPBAR and becomes deposited in the ion exchange resin during coolant purification.

Generation: The purification of storage basin coolant will be performed by processing a slipstream which will be passed through filters and ion exchange resin to remove impurities. This stream is generated only if wet storage of TPBARs is implemented. Current CLWR-TEF plans are for dry storage. Thus this waste stream is not anticipated to be generated per current CLWR-TEF process nowsheet. It is included here for information and in case there is a change in the baseline design.

Annual Quantities: None at this time.

Waste Minimization:

(a) Dry storage of irradiated TPBARs will eliminate this waste stream.

(b) Series operation of two beds will ensure that each bed is used to the point of saturation, thus minimizing resin waste volume.

\section{Treatment Options:}

(a) De-water the resins prior to disposal. De-watering service is available from SEG.

(b) Envirocare will accept de-watered resins for disposal.

(c) Incineration, followed by stabilization or vitrification of residue.

\section{Comments:}

(a) In a typical design, after filtration, the coolant is processed through a pair of mixed bed ion exchangers. By providing for series operation, the resin in the first bed in the series can be fully utilized to minimize resin waste volume. The beds in each pair can be interconnected so that when the first bed saturates, inlet is switched to the second bed, the resin in the saturated bed is replaced, and it then becomes the new second bed. 


\section{APPENDIX C \\ Treatment and Disposal of CLWR-TEF Waste}

The major sources of CLWR-TEF waste are personal protection equipment (PPE) job control waste (JCW) from routine maintenance, the spent target/basket from extraction and spent uranium or magnesium beds. The primary treatment for the JCW is incineration at the SRS Consolidated Incineration Facility (CIF) followed by cement stabilization of the ash residue or compaction followed by disposal in the SRS E-Area Vaults. The primary treatment for spent targets is volume reduction followed by disposal in the E-Area Vaults Tritium Silos. The possibility of melting and recycling stainless steel with slight tritium contamination should also be considered.

Solid waste containing RCRA characteristic metals not amenable to recycling would have to be encapsulated to minimize leaching after disposal. The EPA Hazardous Waste Codes with Subcategories can be found in Appendix G.

Appendix C describes the treatment and disposal options for CLWR-TEF waste, evaluates relevant existing and planned treatment facilities at SRS and other DOE sites, and describes relevant waste treatment technologies for CLWR-TEF waste. This discussion is organized into the following sections:

C1. CLWR-TEF Waste Disposition

C1.1 Low-Level Waste

C1.2 Mixed Low-Level Waste

C1.3 Hazardous Waste

C2. Existing and Planned SRS Waste Treatment, Storage and Disposal Facilities

C2.1 E-Area Vaults

C2.2 Consolidated Incineration Facility

C2.3 Hazardous/Mixed Waste Storage Pads/Buildings

C2.4 Sanitary Landfill

C2.5 Effluent Treatment Facility

C2.6 Sanitary Sewerage Treatment Facility

C2.7 Hazardous Waste/Mixed Waste Disposal Facility

C2.8 Prohibited Wastes

C3. Other DOE and Commercial Waste Treatment Facilities

C3.1 Hanford

C3.2 Nevada Test Site

C3.3 SEG

C3.4 DSSI 


\section{C3.5 Envirocare}

C3.6 GTS Duratek

C4. Treatment Technologies

C4.1 Compaction

C4.2 Thermal Desorption

C4.3 Incineration

C4.4 Stabilization

C4.5 Vitrification

C4.6 Encapsulation

C4.7 Metals Recovery 


\section{C1. CLWR-TEF Waste Disposition}

The CLWR-TEF wastes will be managed for treatment and disposal according to waste type. SRS and off-site or vendor-operated waste treatment, storage and disposal (TSD) facilities that may be used to treat, store or dispose of CLWR-TEF waste are shown in Fig. C-1. The CLWRTEF-relevant TSD facilities are presented in plain shaded boxes. The shaded and shadowed boxes denote CLWR-TEF waste TSD facilities that are either off-site or at SRS but operated by vendors (Envirocare, GTS Duratek, Compaction and the Sanitary Landfill at SRS being developed by the Three River Solid Waste Authority).

Non-CLWR-TEF off-site and SRS waste streams and TSD facilities are shown in Fig. C-1 for information only and for completeness. These wastes and facilities include: TRU Waste, HighLevel Waste, In-Tank Precipitation (ITP)/Late Wash, Defense Waste Processing Facility (DWPF), Saltstone, TRU Storage Pads, DWPF Storage Building, Saltstone Vaults, and the Burial Grounds, which were previously used for low-level radioactive waste (LLRW) disposal, but which have been replaced by the E-Area Vaults. Off-site waste facilities of interest under development are the Waste Isolation Pilot Plant (WIPP) for TRU waste disposal in New Mexico and the Yucca Mountain HLW repository in Nevada.

\section{C1.1 Low-Level Waste}

The vast majority of radioactive waste generated by the CLWR-TEF is expected to be low-level radioactive waste. CLWR-TEF LLRW is expected to consist of both highly radioactive remotehandled waste from extraction and post-extraction contact-handled tritium waste. Remotehandled LLRW includes spent target waste from extraction. Maintenance waste, discarded extraction particulate filters and failed equipment from extraction are also expected to be remotehandled. The high gamma radiation level originates in the irradiated stainless steel cladding and target. It is expected to contain Co-60 and other gamma-emitting radionuclides. Definitive analytical characterization of irradiated TPBARs is not complete, only calculated radionuclide distributions are available (Ref. 18). Post-extraction process LLRW is expected to be all contacthandled. Assuming all gamma contaminants in all process, liquid and gas effluent streams leaving the extraction area of the CLWR-TEF are trapped, the only significant radioactive contaminant should be tritium. This waste will consists mostly of job control waste (shoe covers, plastic sheeting, gloves, plastic suits, laraf paper, absorbent wipes, etc.) from process operations and analytical waste with trace tritium contamination, as well as more highly tritium-contaminated process equipment waste (piping, valves and fittings, gauges, pumps, metal hydride beds, catalyst beds, and zeolite beds). The only routine process waste should be, depending on CLWR-TEF design, spent magnesium or uranium beds. 
[This page intentionally left blank] 


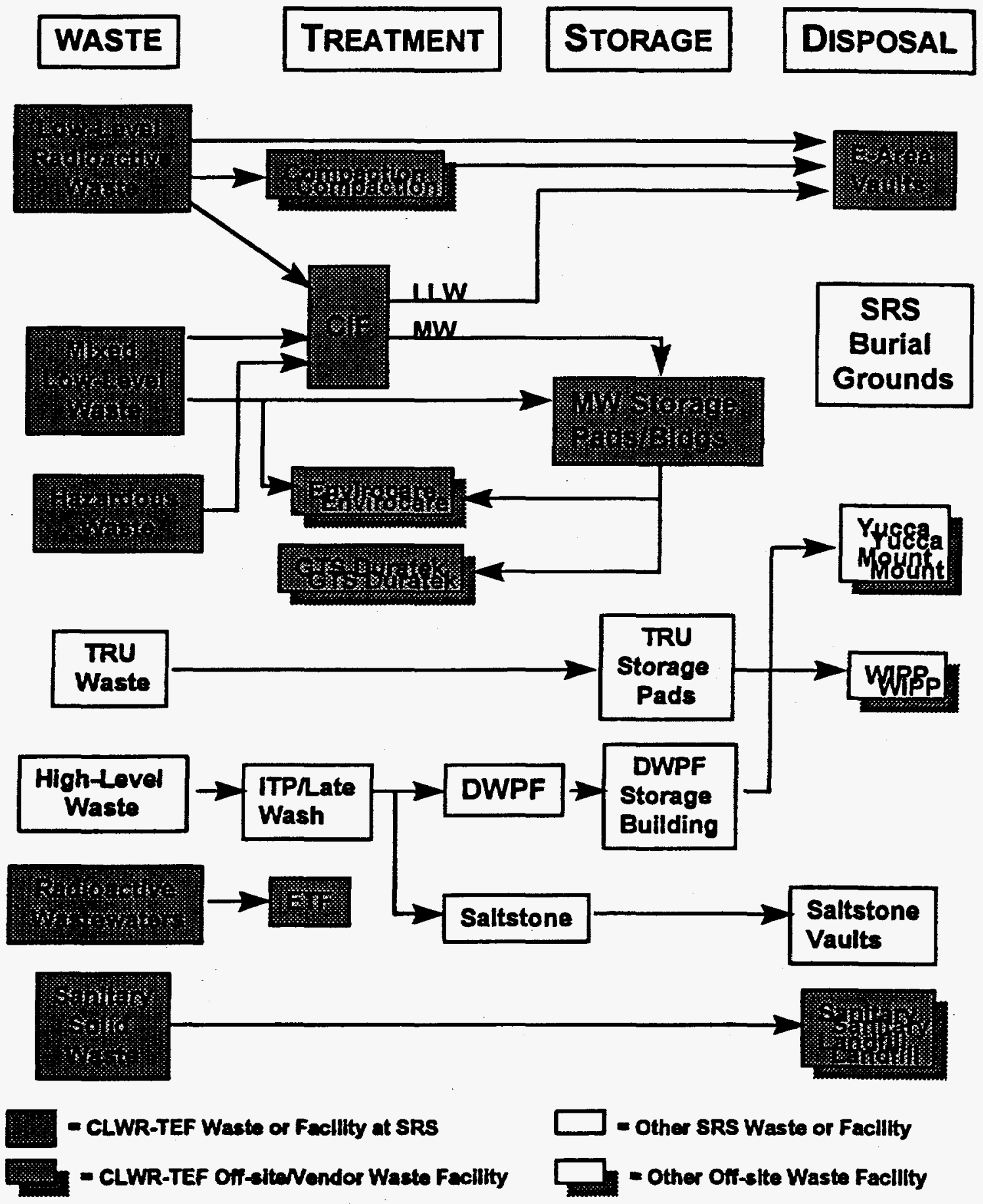

Fig. C-1. CLWR-TEF Waste Management Facilities 
All containerized SRS LLRW are projected to be disposed of in the E-Area Vaults (EAV). The E-Area Vaults are divided into Low-Activity Waste (LAW) Vaults, Intermediate Level Tritium Vaults (ILTV), and Intermediate Level Non-Tritium Vaults (ILNTV). LLRW with tritium content of less than $1000 \mathrm{Ci}$ and minimal tritium off-gassing (less than $4 \mathrm{E}-5 \mu \mathrm{Ci} / \mathrm{cc}$ ) may be disposed of in B-25 containers in the LAW vaults. The LLRW spent target waste from extraction is proposed to be disposed of in the ILTV tritium silos originally designed for current SRS extraction crucible waste. These silos have a current disposal limit of 290,000 curies of tritium per container. The ILTV also have a bulk cell for disposal of tritiated waste which contains more than 1000 curies of tritium per container.

The CLWR-TEF LLRW designated for the E-Area Vaults disposal must meet WAC 3.17 of the WSRC 1S Manual (Interim Rev. 1 as of 11/30/97). If characterization of the TEF spent TPBAR and baseplate waste from extraction should indicate that the EAV WAC 3.17 cannot be met, either 1) an exemption would have to be granted, 2) the WAC limits would have to be revised or 3) a new waste disposal facility would have to be built to accommodate this waste. Development of a new WAC for the spent target waste would require conducting a Radiological Performance Assessment to determine long term waste disposal impact on the groundwater and postinstitutional control intruders.

The low-activity tritium-contaminated job control waste may also be segregated for either off-site or on-site compaction, or incineration at the Consolidated Incineration Facility (CIF), prior to disposal in the EAV. Incinerable CLWR-TEF waste going to the CIF must meet the CIF waste acceptance criteria (WAC 3.13 in WSRC 1S Manual). Off-site waste compaction using the SEG compactor in Tennessee must meet WAC 3.17.

\section{C1.2 Mixed Low-Level Waste}

Incinerable CLWR-TEF mixed low-level waste with low rad contamination and trace amounts of RCRA metals will be treated in the CIF. Non-incinerable wastes such as surface-contaminated lead may be sent to a commercial vendor such as Envirocare for macroencapsulation. GTS Duratek is a potential vendor for vitrifying mixed waste in the future; it has a contract to vitrify SRS M-Area mixed waste sludges.

No DOE facility is currently authorized to dispose of MLLW on site, however, some shipments of MLLW to Hanford for storage have been allowed by DOE on a case-by-case basis. These shipments have been primarily either mixed waste containers whose surface dose rate exceeded $200 \mathrm{mrem} / \mathrm{hr}$ and therefore required remote handling, "special waste", defined as waste that requires special handling, or unique waste, such as decommissioned reactor vessels. Hanford, NTS and Savannah River all have planned MLLW disposal facilities that have passed Key Decision-zero or KD-0. This means that these sites have a recognized mission need and have been approved for funding for conceptual design of mixed waste disposal facilities. However, these projects have been placed on hold and DOE is revising its strategy for mixed waste disposal. 


\section{C1.3 Hazardous Waste}

Incinerable CLWR-TEF hazardous waste that meet the CIF WAC 3.13 will be incinerated in the CIF. Per current practice, other CLWR-TEF hazardous waste can be disposed of at any number of DOE or SRS-approved commercial facilities.

\section{C2. Eristing and Planned SRS Waste Treatment, Storage and Disposal Facilities}

\section{C2.1 E-Area Vaults (EAV)}

The E-Area Vaults at SRS are designed to dispose of low-level and intermediate level radioactive waste. Intermediate-level waste is a subset of low-level waste. The term is used to designate low-level waste that have high levels of gamma activity and that may require non-contact handling.

As stated in C1.1, the E-Area Vaults are divided into the Low-Activity Waste (LAW) Vaults, the Intermediate Level Tritium Vaults (ILTV), which include a Bulk Cell and Tritium Silos, and the Intermediate Level Non-Tritium Vaults (ILNTV). Within the boundary of the EAV is a storage building for long-lived radioisotope waste such as reactor ion exchange resin containing C-14 and areas set aside for shallow land or trench burial of containerized Naval Reactor waste components and other cemented waste forms.

LLRW with tritium content of less than $1000 \mathrm{Ci}$ and minimal tritium off-gassing (less than $4 \mathrm{E}-5$ $\mu \mathrm{Ci} / \mathrm{cc}$ ) may be disposed of in B-25 and other approved containers in the LAW Vaults. The LAW Vaults building in operation is approximately 650 feet by 145 feet by 25 feet in height $(200 \mathrm{~m} \mathrm{x}$ $44 \mathrm{~m} \times 8.2 \mathrm{~m}$ ) and is divided into 12 cells. The concrete end and side walls are $24^{\prime \prime}$ thick. The concrete interior walls and base slab are 12" thick. The LAW Vaults building has storage capacity for 12,000 B-25 containers, stacked 4 high. The original plans were to construct 21 vaults of this design. Due to successful waste minimization efforts at SRS and cost considerations, the number of vaults will likely be scaled back.

The Intermediate Level Vaults are subsurface concrete structures designed to handle and dispose of non-contact waste. Two of the seven ILV cells are designed specifically to handle tritium waste: a bulk cell and a cell containing 140 silos designed to accept tritium extraction crucible waste. The ILV base slab, side and end walls are constructed of $30^{n}$ concrete. The interior walls

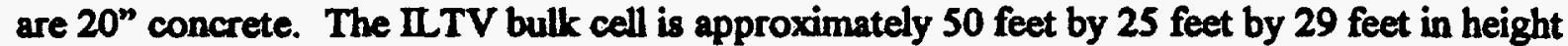
$(15.2 \mathrm{~m} \times 7.6 \mathrm{~m} \times 8.8 \mathrm{~m})$. It is used for disposal of tritiated waste which contains more than 1000 curies of tritium per container, usually waste equipment wch as zeolite beds and diffusers. The tritium silos are approximately 20 feet deep and tapered from $30^{\prime \prime}$ to $20^{\prime \prime}$ in diameter at the bottom (SRS Drawing W2020320). Top shielding for the silos are provided by $40^{n}$ thick concrete plugs. The ILTV silos have a current disposal limit of 290,000 curies of tritium each. Classified tritium waste is also disposed of in the IITV.

The E-Area Vaults are operated by the Solid Waste Division. The governing WAC is WAC 3.17 of the 1S Manual. 


\section{C2.2 Consolidated Incineration Facility (CIF)}

The Consolidated Incineration Facility, located between S-Area and H-Area at the SRS, is designed to incinerate both solid and liquid wastes from several generators around the SRS. Liquid waste can be sent by container or pipeline. Solid waste for incineration should be packaged in standard 21 "x21"x21" cardboard boxes.

The CIF is a rotary kiln incinerator with a secondary combustion chamber. The liquid waste is fed into both the rotary kiln's primary combustion chamber and the secondary combustion chamber. Solid waste is fed into the primary combustion chamber. Organic materials are combusted to water and carbon dioxide. Off-gas is quenched, scrubbed in a caustic solution and discharged to the atmosphere.

Non-combustible ash materials are collected, mixed with Portland cement and other stabilizing additives, and cast into stable solid waste forms referred to as "ashcrete". The ashcrete system also stabilizes blowdown liquid from the quench and scrubber ("blowcrete"). The ashcrete system could also be used to encapsulate other small waste components that could be mixed directly with the ash.

The estimated CIF thermal capacity of 18 million BTU/hr is based on the design estimate of wastes expected to be in inventory at the time of CIF start-up and on wastes expected to be generated annually after CIF start-up. To maximize the flexibility and utilization of the CIF, the material handling systems for feeding solid and liquid wastes were sized for a greater throughput than the average annual requirement for each system. The instantaneous capacity of the individual sub-systems are as follows:

- Solid waste to rotary kiln

- Organic liquid waste to rotary kiln

- Aqueous liquid waste to rotary kiln

- Organic liquid waste to secondary combustion chamber
$2025 \mathrm{lbs} / \mathrm{hr}$

$385 \mathrm{lbs} / \mathrm{hr}$

$950 \mathrm{lbs} / \mathrm{hr}$

$302 \mathrm{lbs} / \mathrm{hr}$

The CIF can generally treat any combination of liquids and solids up to the rates listed above, provided that the thermal capacity and other operational limits are not exceeded. The CIF is expected to have excess capacity for treating other SRS and non-SRS DOE incinerable wastes. The schedule for treating other wastes at CIF will be established based on several key factors, including:

- Available thermal capacity

- Concentrations of waste constituents (e.g., hazardous metals) that are controlled by the various CIF environmental permits.

- Concentrations of waste constituents (e.g., chlorides and non-combustibles) that directly influence the amount of bottom ash and off-gas scrubber blowdown generated. When wastes 
that generate significant ash or blowdown are incinerated, the demand on the spare ashcrete unit capacity could become the factor that limits waste feed rates.

The nominal capacities for CIF are $3.5 \times 10^{6} \mathrm{ft}^{3} / \mathrm{yr}\left(100,000 \mathrm{~m}^{3} / \mathrm{yr}\right)$ of solid waste feed and 12,000 $\mathrm{ft}^{3} / \mathrm{yr}\left(340 \mathrm{~m}^{3} / \mathrm{yr}\right)$ of liquid waste feed.

The CIF is operated by the Solid Waste Division. The governing WAC is WAC 3.13 in the SRS IS Manual.

\section{C2.3 Hazardous/Mixed Waste Storage Pads/Buildings}

The CLWR-TEF hazardous and mixed waste that cannot go directly to an off-site vendor for treatment may be stored in a number of storage pads or buildings. Current mixed waste storage facilities include Mixed Waste Storage Buildings 643-29E and 643-43E in E-Area, 645-2N near the Central Shops, and 315-4M and 316-M in M-Area. Mixed waste storage pads are located in the Solid Waste Disposal Facility. Hazardous waste is currently stored at the SRS Waste Management Hazardous Waste Storage Facility. This facility includes Building 645-N and 645$4 \mathrm{~N}$ near the Central Shops, Building 710-B in B-Area and Solid Waste Storage Pads 1, 2 and 3.

Hazardous and mixed waste management is the responsibility of the Solid Waste Division. The governing WACs in the WSRC 1S Manual are WAC 3.07 for mixed waste storage and WAC 3.08 for hazardous waste storage.

\section{C2.4 Sanitary Landrill}

The CLWR-TEF solid sanitary waste is expected to go to a sanitary landfill located on the SRS. The Three River Solid Waste Authority is developing an 1100-acre site on the SRS for a regional landfill. It is anticipated to be in operation prior to the start-up of CLWR-TEF operations. It will provide capacity for receiving sanitary waste from an 8-county area around SRS. It will also provide for demonstrating state-of-the art treatment technologies for solid waste. The landfill should be a subtitle.D landfill with double liners and a leachate collection system.

Sanitary waste management is the responsibility of the Solid Waste Division. The governing WAC is WAC 3.09 in the SRS 1S Manual.

\section{C2.5 Effluent Treatment Facility (ETF)}

The Effluent Treatment Facility (ETF), Building 241-81H, located off Road E near the H-Area Tank Farm at the SRS, is a multi-purpose plant for treating highly diluted aqueous waste. Waste generally arrives at ETF by pipeline. There are proposals to provide a station for unloading liquid waste from containers or tank cars. The ETF consists of a number of separation steps, including ultrafiltration, carbon bed filtration and ion exchange

To determine the compatibility or suitability of a proposed new liquid waste stream with the ETF ion exchange process, a treatability study is first conducted to determine the compatibility of the constituents of concern with the ion exchange resin that will be used for absorption. The waste is 
pumped from the feed tank to the ion exchange beds. The constituents of concern should bind tightly to the ion exchange resins to pass TCLP, allowing the spent resin to be disposed of as a non-hazardous low-level waste. Carbon beds are designed to remove dissolved organics from wastewaters. They can also remove some dissolved metal and other inorganic contaminants.

Decontaminated ETF liquid effluent is collected in tanks for analysis, which should confirm that the liquid meets release specifications and NPDES limits. Liquid that meets specifications is released to a surface outfall. In the unlikely event that the treated effluent fails to meet release specification, it can be recycled for reprocessing. No liquid is released without passing a final assay.

The ETF has a demonstrated maximum throughput of about $130 \mathrm{gpm}$. Acceptance of waste streams at ETF is on a case-by-case basis, depending on the quantity of waste and concentration of the constituent of concern. Since the ETF processes cannot remove tritium, it is suggested that tritium content in CLWR-TEF liquid effluent to the ETF should be less than [TBD] $\mu \mathrm{Ci} /$ liter.

The ETF is operated by the High-Level Waste Division. There are currently no formal WACs that apply to the ETF.

\section{C2.6 Sanitary Sewage Treatment Facility}

Sanitary sewage at SRS is treated at a centralized facility near F-Area and at a number of local facilities. CLWR-TEF sewage will likely be piped and pumped and to the central sanitary facility constructed in 1995. Sewage is processed using an oxidation ditch, an intra-channel clarifier, chlorination, settling ponds, and ultraviolet disinfection. The sewage treatment facility has a capacity for processing 1.05 million gallons per day.

The sanitary sewage treatment facilities are operated by Site Services Division. There is no applicable WAC for this facility.

\section{C2.7 Hazardous Waste/Mired Waste Disposal Facility (HW/MW DF)}

The Hazardous Waste/Mixed Waste Disposal Facility (HW/MW DF) at SRS was a line-item project whose status is uncertain at this point. A project re-scope that will impact project cost and schedule was submitted to DOE for review/approval in 1995. No action has been taken since that time and project personnel have been re-assigned. NEPA documentation was also prepared for the HW/MW DF project. A decision by DOE as to whether an Environmental Assessment or Environmental Impact Statement will be required is also pending. Until the NEPA and project scope questions have been answered, schedule and milestones cannot be defined. It is possible that this project may be canceled altogether.

As currently designed, the HW/MW DF will include treatment systems for waste handling (sorting and size reduction), acid leaching and chemical precipitation, stabilization of solid and liquid wastes, soil washing, macroencapsulation of lead, roasting/retorting of mercury-contaminated soil and equipment, amalgamation of elemental mercury, and wastewater cleanup. Systems applicable to treatment of the CLWR-TEF waste are the macroencapsulation and stabilization units. 


\section{C2.8 Prohibited Wastes}

The waste destined for a particular treatment, storage or disposal facility at SRS must, in general, meet the Waste Acceptance Criteria of that facility. Exemptions or deviations may be granted in the case of noncompliance. For general guidance, Savannah River Site waste treatment, storage and disposal facilities will not accept the following for disposal, without special approval:

- Aerosol cans (pressurized, non-empty)

- Compressed gas cylinders

- Biologic, pathogenic or infectious materials

- Waste that can detonate or explode

- Waste that can generate toxic fumes or gases

- Incompatibles wastes in the same container

- Pyrophorics

- Shock sensitive waste

- Waste containing cyanide or sulfides not chemically bound

- Wastes that are only corrosive (D002) must be neutralized prior to disposal

- Uncontainerized waste

- Wastes containing polychlorinated biphenyls $\geq 50 \mathrm{ppm}$ (TSCA waste)

- Unidentified, uncharacterized, or poorly characterized waste.

In addition, non-hazardous waste should not be sent to the hazardous waste facility and sanitary waste should not be sent to the EAV.

For definitive guidance, the reader should refer to the complete set of Waste Acceptance Criteria for the specific waste treatment, storage and disposal facility of interest.

\section{C3. Other DOE and Commercial Waste Treatment Facilities}

In addition to SRS, several other DOE sites are capable of treating and/or disposing of low-level and mixed low-level waste. Several commercial vendors have also been approved for treating low-level and mixed low-level wastes.

Relevant treatment facilities for CLWR-TEF waste at SRS, INEL, Oak Ridge, Pantex, and Hanford are summarized in Table Cl. The Nevada Test Site (NTS) is a potential disposal site for low-level waste, but has no on-site treatment facilities. Pantex has only encapsulation facilities. Hanford and LANL have existing and/or planned compaction capabilities. Only those facilities that have at least passed DOE KD-0, Approval of Mission Need, are listed. Typically at this stage, conceptual design and the preparation of NEPA documentation have been initiated. 
Table C1

Existing and Planned DOE Waste Treatment Facilities Relevant for CLWR-TEF Waste

\begin{tabular}{|c|c|c|c|c|c|}
\hline Site & Facility & Treatment(s) & $\begin{array}{l}\text { Allowable } \\
\text { Waste }\end{array}$ & $\begin{array}{c}\text { Design } \\
\text { Capacity } \\
\mathbf{m}^{3} / y \mathbf{r}\end{array}$ & $\begin{array}{c}\text { Eatimated } \\
\text { Start-up Date }\end{array}$ \\
\hline \multirow[t]{4}{*}{ SRS } & $\begin{array}{l}\text { Consolidated } \\
\text { Incineration Facility } \\
\text { (CIF) }\end{array}$ & Incineration & $\begin{array}{l}\text { Low-level } \\
\text { Mixed }\end{array}$ & $\begin{array}{l}100,424 \text { solids } \\
340 \text { liquids }\end{array}$ & Operational \\
\hline & CIF Ashcrete Fecility & Stabilization & $\begin{array}{l}\text { Low-level } \\
\text { Mixed } \\
\end{array}$ & 2,426 & Operational \\
\hline & 253-H Compactor & Compection & Low-level & 1,600 (est) & $\begin{array}{l}\text { System has } \\
\text { been placed } \\
\text { in standby }\end{array}$ \\
\hline & $\begin{array}{l}\text { Hazardous } \\
\text { WasteMixed Waste } \\
\text { Disposal Facility }\end{array}$ & $\begin{array}{l}\text { Macroencapsulation, } \\
\text { Stabilization }\end{array}$ & $\begin{array}{l}\text { Low-level } \\
\text { Mixed }\end{array}$ & $\begin{array}{l}73 \text { (macro.) } \\
484 \text { (stab.) }\end{array}$ & $\begin{array}{l}\text { Project on- } \\
\text { hold }\end{array}$ \\
\hline \multirow[t]{2}{*}{ Hanford } & $\begin{array}{l}\text { Waste Receiving \& } \\
\text { Processing Facility, } \\
\text { WRAP I }\end{array}$ & $\begin{array}{l}\text { Compaction } \\
\text { Stabilization }\end{array}$ & Low-level & 1400 & Operational \\
\hline & $\begin{array}{l}\text { Waste Receiving } \\
\text { Processing Facility, } \\
\text { WRAP II }\end{array}$ & $\begin{array}{l}\text { Macroencap- } \\
\text { sulation; } \\
\text { Stabilization }\end{array}$ & $\begin{array}{l}\text { Low-level, } \\
\text { Mixed }\end{array}$ & 1500 & FY99 \\
\hline \multirow[t]{2}{*}{ INEI } & $\begin{array}{l}\text { Waste Experimental } \\
\text { Reduction Fucility, } \\
\text { WERF }\end{array}$ & $\begin{array}{l}\text { Incineration } \\
\text { atabilization }\end{array}$ & $\begin{array}{l}\text { Low-level, } \\
\text { Mixed }\end{array}$ & $\begin{array}{l}49,625 \text { (incin) } \\
2765 \text { (stab.) }\end{array}$ & Operational \\
\hline & $\begin{array}{l}\text { HEPA Filter Leaching } \\
\text { System }\end{array}$ & $\begin{array}{l}\text { Chemical } \\
\text { Extraction }\end{array}$ & $\begin{array}{l}\text { Low-tevel, } \\
\text { Mixed }\end{array}$ & 83 & IBD \\
\hline Onk Ridge & TSCA Incineratox & Incineration & $\begin{array}{l}\text { Lowtevel, } \\
\text { Mixed }\end{array}$ & 15,716 & $\begin{array}{l}\text { Operating, } \\
\text { liquids } \\
\text { solids }\end{array}$ \\
\hline \multirow[t]{2}{*}{ Pantex } & Building 11-9 & Encapoulation & $\begin{array}{l}\text { Low-devel } \\
\text { Mixed }\end{array}$ & 43 & TBD \\
\hline & $\begin{array}{l}\text { Hazardous Waste } \\
\text { Treatment \& } \\
\text { Procesaing Facility }\end{array}$ & $\begin{array}{l}\text { Comprection, } \\
\text { Stabilization, } \\
\text { Encapreulation }\end{array}$ & Low-level & 500 & TBD \\
\hline
\end{tabular}


If DOE grants an exemption for shipment of CLWR-TEF waste to commercial treatment facilities, Diversified Scientific Services (DSSI) and Scientific Ecology Group (SEG), both in Oak Ridge, TN, could be utilized for low-level PPE/JCW waste streams. However, their tritium annual release limits are limited to less than $600 \mathrm{Ci}$. Both DSSI and SEG have thermal treatment facilities that can accept low-level, tritium-contaminated waste, and SEG also has stabilization and compaction capabilities. The Envirocare facility in Utah, though more distant from SRS, is another commercial vendor capable of treating CLWR-TEF mixed waste through macroencapsulation or stabilization. DOE Order $5820.2 \mathrm{~A}$ requires that all DOE LLW be disposed of at a DOE disposal facility, unless an exemption is obtained. Commercially treated CLWR-TEF mixed waste may have to be returned to SRS for storage and eventual disposal.

At the present time, three DOE disposal sites are known to accept off-site radioactive waste for disposal: SRS, Hanford, and the Nevada Test Site. Barring policy changes, CLWR-TEF lowlevel waste that meets the site's WAC could be sent to one or more of these facilities. A formal application and approval process must be completed before waste can be shipped to any of these sites.

The Waste Acceptance Criteria (WAC) of facilities that could be used for disposal of CLWR-TEF low-level and mixed waste are summarized in the following discussion. All waste approved for off-site treatment and/or disposal must be packaged according to Department of Transportation regulations for shipping of hazardous and/or radioactive materials over public roadways.

All three sites require that, upon or immediately after generation and before packaging, the physical and chemical characteristics and radionuclide content of all LLW be determined and recorded for use during all subsequent stages of the waste management process; i.e., on-site treatment, packaging, segregation, transportation, off-site treatment, storage and disposal. Additional site-specific requirements and restrictions may be found in the WAC for each site. General information about the WAC and contacts at the three DOE low-level and mixed waste disposal site is summarized below.

DOE Low-Level Waste Disposal Sites, Contacts and WACs

\begin{tabular}{|l|l|c|l|}
\hline \multicolumn{1}{|c|}{ Site } & \multicolumn{1}{|c|}{ Location } & Site Contact & WAC Document \\
\hline Savannah River & $\begin{array}{l}\text { Portions of Aiken, } \\
\text { Barnwell, and } \\
\text { Allendale Counties, SC }\end{array}$ & $\begin{array}{c}\text { Pam Jenkins } \\
(803) 725-1541\end{array}$ & WSRC-1S \\
\hline Hanford & Richland, WA & $\begin{array}{c}\text { Clay Hawkes } \\
(509) 372-0508\end{array}$ & WHC-EP-0063 \\
\hline Nevada Test Site & Nye County, NV & $\begin{array}{c}\text { Wendy Griffin } \\
(702) 295-5751\end{array}$ & NVO-325, Rev. 1 \\
\hline
\end{tabular}




\section{C3.1 Hanford}

The Hanford Waste Receiving and Processing Facilities (WRAP I and II) are designed to prepare on-site low-level waste (WRAP I) and mixed low-level waste (WRAP IIA) for disposal. WRAP I includes systems for adsorption, compaction, stabilization and packaging. The facility is in the detailed design stage. Ground-breaking ceremonies were held on April 15,1994, and construction is scheduled to be completed in December, 1996. WRAP II, which is at the KD-0 stage, will conduct waste grouting, macrocencapsulation and stabilization operations. An incineration facility with a design capacity of $19,400 \mathrm{ft}^{3} / \mathrm{yr}\left(550 \mathrm{~m}^{3} / \mathrm{yr}\right)$ is planned but not approved.

Hanford has established WAC WHC-EP-0063-4, UC-721 (November 1993) for off-site generators of radioactive waste interested in sending waste to Hanford.

\section{C3.2 Nevada Test Site (NTS)}

The Nevada Test Site (NTS) is a potential disposal site for low-level waste, but has no on-site treatment facilities. The NTS has established WAC NVO-325, Rev 1, June 1992, "Nevada Test Site Defense Waste Acceptance Criteria, Certification and Transfer Requirements, "for off-site generators interested in sending waste to NTS.

\section{C3.3 Scientific Ecology Group (SEG)}

1560 Bear Creek Road, Oak Ridge, TN 37831-2530, Tel: (615) 481-0222

SEG passed from Westinghouse ownership to become a subsidiary of GTS Duratek in1997. The SEG facility near Oak Ridge, Tennessee, is permitted and capable of compacting, incinerating and stabilizing low-level radioactive waste. Other capabilities include metal melting, wet waste processing, decontamination, processing of sealed radioactive sources and drying/incineration of resins and sludges. SEG is not permitted to treat mixed waste from outside the state of Tennessee and it is not permitted as a disposal site.

The governing WAC for waste receipt and treatment at SEG is OP-4.35. Different wastes and treatments are governed by different packaging, receipt, waste form, radiation level and radiological criteria. Some CLWR-TEF relevant criteria for compaction, incineration and metal melting are discussed below.

Generally, the following wastes are not acceptable for compaction:

- RCRATSCA hazardous wastes

- Explosives

- Pyrophoric materials

- Flammable solids

- Liquid

- Absorbed liquid 
- Smoke detectors

- Gas containers

- Gas sources

- Aerosol cans (unless punctured)

- Animalbiological waste

- $\mathrm{Kr}$-85 Electron tubes

Bulk and non-bulk dry active waste of most cellulosic and polymeric materials are acceptable for incineration. Materials not acceptable for incineration include the following:

- Sharps

- Metal

- Glass

- Polyvinyl chloride (PVC)

- Asbestos

- RCRATSCA hazardous wastes

- Explosives

- Pyrophorics

Contaminated oils and aqueous liquids are accepted for incineration. Contaminated oils acceptable for incineration include petroleum-based lubricating and heating oils such as kerosene, hydraulic oil, diesel fluid and other flammable oils. There are restrictions on viscosity, solids and aqueous liquid content, flashpoint and RCRA/TSCA limits. Of particular interest to CLWR-TEF is that the tritium content must be $\leq 3.0 \times 10^{-3} \mu \mathrm{Ci} / \mathrm{ml}$ and halogens must be $\leq 1000 \mathrm{ppm}$.

Similarly, aqueous liquids may be incinerated at SEG. There are restrictions on $\mathrm{pH}, \%$ solids, chelating agents and oil content, flashpoint and RCRATSSCA limits. As with contaminated oil, the tritium content must be $\leq 3.0 \times 10^{-3} \mu \mathrm{Ci} / \mathrm{ml}$.

C3.4 Diversified Scientific Services, Inc. (DSSI)

657 Gallaher Road, Kingston, Tennessee 37763, Tel: (423) 376-8702

DSSI is a subsidiary of Chemical Waste Management, Inc. The DSSI facility near Oak Ridge Tennessee is permitted and capable of energy recovery from low-level and mixed waste.

\section{C3.5 Envirocare}

46 West Broadway, Suite 240, Salt Lake City, Utah 84101, Tel: (801) 532-1330

Envirocare of Utah, Inc. is the only commercial facility in the United States permitted to accept MLLW for disposal. Envirocare is licensed to accept both low-level and mixed waste, including NRC Class A LLW, debris, by-product material (e.g., uranium and thorium mill tailings), and Flisted debris. Concentrations of listed contaminants must be below RCRA treatment standards. In addition to requiring a detailed description of the waste, its history, physical properties, and 
chemical and radioactive constituents, Envirocare requires that the following analytical data be supplied for each MLLW:

- Gamma spectral analysis for all naturally occurring and man-made radionuclides. If radionuclides are known to be present that cannot be easily quantified by gamma spectroscopy, radiochemical analysis must be provided.

- Paint Filter Liquids Test, EPA Method 9095, for dry solids and stabilized wastes.

- TCLP results for heavy metals and volatile and semi-volatile organics.

- Proctor test for soils.

All analyses must be performed at either a laboratory approved by Envirocare or an EPA Contract Laboratory Program laboratory. Five 1-kg representative waste samples must be sent to Envirocare and may be analyzed by them prior to waste acceptance.

\section{C3.6 GTS Duratek}

A contract has been awarded to GTS Duratek to design, build and operate a vitrification process, which will transform SRS M-Area mixed wastes into a form meeting land disposal restrictions (LDRs). M-Area wastes that make up the design basis for the vitrification process are:

- M-Area plating line sludge from supernatant treatment

- M-Area high nickel plating line sludge

- M-Area treatability test samples

- Filtercake from Mark 15 filters

- Nickel plating line solution

- Plating line sump material

The above wastes will be blended into a homogenized mixture in existing tanks in $M$ Area. Stabilizing chemicals and glass-forming materials will be added to the mixture to make vitrification feedstock. The feedstock will be pumped into a melter at a temperature of about $1150^{\circ} \mathrm{C}$. The glass-forming materials chemically bond the constituents of concern into a matrix of borosilicate glass. The glass is placed into containers for storage and disposal. The entire operation takes place in a structure with secondary confinement and air emission control equipment.

The Duratek vitrification facility is being sized for about 5 tons of throughput per day. After treating the M-Area waste it may be possible to treat other mixed or low-level waste streams, including CLWR-TEF wastes. To be a viable option, it is also assumed the service life of the vitrification facility may be extended. A new contract or contract modification would have to be established with GTS Duratek.

\section{C4. Treatment Technologies}

Treatment technologies applicable to CLWR-TEF waste include compaction, thermal desorption, incineration, stabilization, vitrification, encapsulation and metals recovery. The following 
descriptions of the technologies are taken from the APT Process Waste Assessment (SNL Report SAND94-2217, UC-721, September 1995). Several descriptions have been modified to apply more specifically to CLWR-TEF waste.

\section{C4.1 Compaction}

While the greatest volume reduction of PPE job control waste would be achieved through incineration, where this is not feasible, compaction should be seriously considered. During compaction a drum of waste may experience an area force of 4-5M lbs, depending on the equipment. Under this force, job control waste usually reaches a density of $55-60 \mathrm{lbs} / \mathrm{ft}^{3}(880-950$ $\mathrm{kg} / \mathrm{m}^{3}$ ). This corresponds to a volume reduction factor of 3-5. Trace amounts of tritium poses no particular problem for compaction of less contaminated waste, such as PPE job control waste. Compaction of SRS job control low-level waste has been done at SEG in Oak Ridge in 1996. Compacted waste was returned to SRS for disposal in the EAV.

To maximize utility of the EAV tritium bulk cell and silo capacities, volume reduction of HEPA filters, spent target rods, and baseplates, if any, is highly desirable. Target rod assemblies cut from baseplates will volume reduce to less than 1/2 to 1/3 of their original bulk volumes. HEPA filters may be compacted similarly to job control waste. One major consideration would be the activity level of the HEPA filter waste.

\section{C4.2 Thermal Desorption}

Thermal desorption consists of heating waste to a point where volatile liquid contaminants can be driven off. The vapor may be condensed by cooling or absorbed in activated carbon. Since waste containing $>1 \%$ free standing liquid is not acceptable for disposal, this process is often used to drive off residual liquid prior to waste compaction. If a radioactive waste is mixed due to the presence of organic solvents, thermal desorption removes the hazardous constituents, which by use of the debris rule, leaves a low-level waste. This treatment can potentially be used for CLWR-TEF waste streams such as absorbent wipes and solvent rags; however, if activated carbon is used, it becomes a secondary waste stream that must be treated (incinerated) or disposed of.

\section{C4.3 Incineration}

Incineration is the thermal decomposition of organic constituents through high temperature (760 $1550^{\circ} \mathrm{C}$ ) oxidation reactions. Hydrocarbon wastes are converted to carbon dioxide and water vapor; wastes containing nitrogen, sulfur, and/or halogens produce nitrites, nitrates, ammonia, sulfites, sulfates, and halogen acids, respectively. Air particulates are filtered and exhaust gases are cooled, scrubbed, and neutralized in an air emissions control system prior to release to the system exhaust stack. Ash residues can be stabilized in cement or vitrified into a glass-like solid for disposal.

Solid wastes are generally treated in a rotary kiln furnace or a fixed hearth furnace. Wastes are fed to the combustion chamber a number of different ways: using rams, gravity feed, air lock feeders, vibratory or screw feeders, or belt feeders. Containerized waste is gravity-fed or ramfed. The rotary kiln furnace is a refractory or metal-lined cylinder, mounted at a slight incline 
from horizontal, that slowly rotates to enhance the mixing of solids with combustion air. A forced-draft air circulation system provides oxygen for combustion and turbulence for mixing. The rotation also moves the ash to the lower end of the kiln, where it is removed. Rotary kiln systems usually have a secondary combustion chamber, or afterbumer, following the kiln, for further combustion of volatilized waste components.

Fixed hearth, or controlled air or starved air incineration, is a two-stage process. Waste is ramfed into the primary chamber, where it is burned in a "starved" atmosphere whose oxygen content is insufficient for complete combustion. The products of incomplete combustion, primarily carbon monoxide and volatile hydrocarbons, pass into a secondary chamber where additional air is injected to complete the combustion process. Due to the reduced air flow in the primary chamber, combustion gas velocities are lower, and, as a result, there is less entrainment and transport of ash particulates into the secondary chamber and the exhaust gases.

An innovative technology that has several advantages for incineration of radioactive waste is the plasma arc centrifugal furnace. This system uses plasma energy to vitrify material dropped into a tub spinning at 20-50 rpm. The tub has an axial hole for tapping slag, which cools into a glasslike solid that is a leach-resistant, homogeneous product. A metal layer forms on top of the slag, and can be drawn off separately. Organics are burned to completion in a secondary combustion chamber. The advantages of this system for radioactive waste treatment are:

- Whole drums of waste can be inserted and treated.

- Metals separation, combustion of organics and solidification of residue can be achieved with a single process.

- Because there is only one system, waste handling is minimized.

Incineration is the recommended treatment for incinerable CLWR-TEF job control waste. Shredding of this waste prior to combustion will increase combustion efficiency, however, it is not necessary and is not planned for feeding the CIF at this time. Incineration followed by vitrification or stabilization of residues will generally reduce the initial waste volume by about a factor of 20. During trial burns, the Waste Experimental Reduction Facility (WERF) incinerator at the INEL has achieved volume reduction factors as high as $\mathbf{8 0}$.

Incineration of tritiated waste will result in tritium contamination in the exhaust gases. Some of this will adhere to particulates and be trapped in the exhaust HEPA filters. As exhaust gases are rapidly cooled and water vapor condenses, some of the remaining tritium should be trapped by the scrubber system; however, most will go up the stack as tritiated water vapor (J. D. Brady, "Fate of Tritium, Carbon-14, and Iodine-131 in Wet Scrubber Air Pollution Control Systems on Chemical and Medical Waste Incinerators", 1992 Incineration Conference, Albuquerque, New Mexico, May 11-15, 1992.). Stack gas should be monitored so that the permitted tritium release limit is not exceeded. Exhaust gas filters and scrubber solutions will be secondary waste streams. 


\section{C4.4 Stabilization}

Stabilization immobilizes hazardous heavy metals by chemically binding them in a solid matrix. This decreases the potential for metals to leach out after disposal if the waste were to be exposed to moisture or weak acids. The two most common stabilization agents are Portland cement and lime/pozzolan.

While cement-based products are commonly used for stabilization of inorganic solids and aqueous liquids, a series of non-hazardous compounds based on Montmorillonite clay can be used to stabilize aqueous liquids, organic liquids such as used oil, and organic/aqueous liquid mixtures. These compounds are sold under the trade names Aquaset ${ }^{\mathrm{TM}}$ and Petroset $^{\mathrm{TM}}$.

The estimated total annual volume of primary CLWR-TEF waste streams for which stabilization is the proposed treatment is small, $<.5 \mathrm{ft}^{3}\left(0.1 \mathrm{~m}^{3}\right)$. This waste is primarily highly tritiated oil or water not suitable for the CIF.

\section{C4.5 Vitrification}

Vitrification produces a non-leaching stabilized waste form of high integrity and minimal secondary waste. Vitrification processes involve dissolving waste at high temperatures (1100 $1400^{\circ} \mathrm{C}$ ) in a pool of molten glass that usually consists of soda ash, lime, silica, boron oxide, and other glassmaking constituents. Molten glass is periodically withdrawn from the bottom of the furnace and cooled. This process is an alternative to stabilization for immobilization of incinerator ash prior to disposal. Vitrification is also suitable for ion exchange resins, chemical cleaning and decontamination solutions, and inorganic sludges and slurries; however, from an energy use standpoint, it is only practical for large volume waste streams that will be generated on a regular basis.

Vitrification is an effective means of immobilizing both hazardous inorganic and radioactive constituents. Both alpha and beta emitters will be sealed in the glass matrix, and, if gammaemitting radionuclides are present, the gamma dose rate will be attenuated or reduced as a result of the increased density of the vitrification matrix.

If the new treatment standards proposed by EPA for toxic metals (Proposed Rules, Federal Register, Vol. 58, No. 176, September 14, 1993) are implemented, the Toxicity Characteristic Leaching Procedure (TCLP) concentration limit for chromium will decrease by a factor of 15 , from the current $5.0 \mathrm{mg} / \mathrm{l}$ to $0.33 \mathrm{mg} /$ for non-wastewater. Cemented wastes may not meet this limit, but tests using wastewater treatment sludges and ion exchange resins have shown that vitrified waste should meet this limit (J. B. Mason, "Modular Enviroglass"M Vitrification Technology for Low-Level Radioactive and Mixed Wastes," VECTRA Document No. SP-501001, Rev. 2, VECTRA Technologies, Inc., Richland, WA.).

\section{C4.6 Encapsulation}

Encapsulation is primarily applicable to solid waste containing hazardous metal constituents, such as discarded circuit boards or instrumentation. The waste is shredded, dried, mixed with an 
organic polymer (e.g., polyethylene), thermosetting resin, or asphalt at $120-130^{\circ} \mathrm{C}$, and allowed to cure into a solid mass prior to disposal. As with all waste immobilization processes, the goal is to minimize leaching after disposal. This process is not suitable for wastes that decompose at these temperatures or that contain strong oxidizers such as nitrites, chlorates, or perchlorates that can react with the binder material.

CLWR-TEF waste streams for which encapsulation is the proposed treatment include batteries for which recycling is impractical, instrumentation, and shielding lead, if it is to be used in the extraction area. Macroencapsulation (encapsulating an entire mass, rather than microencapsulation, which coats individual particles of a waste) is the Best Demonstrated Available Technology (BDAT) for radioactive lead solids.

\section{C4.7 Metals Recovery}

Stainless steel waste generated by CLWR-TEF can be recovered and recycled by melting in a rotary kiln or plasma arc furnace under a reducing atmosphere. There is insufficient waste to justify a metal recycling facility just for CLWR-TEF waste. But opportunity exists for participating in metal recycling facilities underway, as described below.

The DOE Office of Technology Development is funding SRS to conduct a demonstration of the beneficial reuse of stainless recycled radioactive scrap metal. Thousands of tons of stainless steel from obsolete reactor heat exchangers with slight tritium contamination may potentially be recycled. B-25 stainless steel containers cast from recycled metal have been made for use at Oak Ridge to support the Transportable Vitrification System. In South Carolina, metal recycling and container fabrication has been contracted to Carolina Metals, Inc., in Barnwell, SC.

Retech Inc. (Ukiah, CA) has signed a cooperative research and development agreement with INEL to develop melting technologies that will allow reuse of radioactivity contaminated metals. Using its plasma arc centrifugal furnace technology, Retech will melt stainless steel containing surrogates for radioactive constituents and evaluate the fate of the surrogates during the process of melting, pouring and cooling the test metal. 


\title{
APPENDIX D \\ Waste Stream Inventory by Waste Type
}

\begin{abstract}
Appendix D lists the masses $(\mathrm{kg})$, volumes $\left(\mathrm{m}^{3}\right)$, and average bulk density $\left(\mathrm{kg} / \mathrm{m}^{3}\right)$ by waste type (low-level radioactive waste, mixed low-level waste, hazardous waste, and radioactive liquid waste) for each waste stream discussed in Appendix B. Intermediate-level waste streams are listed under low-level radioactive waste. Some waste streams are included even though projected quantities are determined to be none at this time. Due to round-off of masses and volumes, several average bulk densities vary slightly that should otherwise be the same (e.g., all job control waste streams should have the same average bulk density).
\end{abstract}




\section{CLWR-TEF Low-Level Radioactive Waste Streams}

\begin{tabular}{|c|c|c|c|c|}
\hline $\begin{array}{l}\text { Waste Stream } \\
\text { Number }\end{array}$ & $\begin{array}{l}\text { Waste Stream } \\
\text { Description }\end{array}$ & $\begin{array}{l}\text { Mass } \\
\text { kg/yr }\end{array}$ & $\begin{array}{l}\text { Volume } \\
\mathrm{m}^{3} / \mathrm{yr}\end{array}$ & $\begin{array}{c}\text { Bulk Density } \\
\mathrm{kg} / \mathrm{m}^{3}\end{array}$ \\
\hline$\overline{\mathrm{B} 1}$ & Job Control Waste (H-3) & 10,000 & 75 & 133 \\
\hline B2 & Job Control Waste (Uranium) & 770 & 5 & 154 \\
\hline$\overline{\text { B3 }}$ & Job Control Waste (Extraction) & 40,000 & 300 & 133 \\
\hline B5 & Nonhazardous Equipment (H-3) & 6,800 & 5 & 1,360 \\
\hline $\mathbf{B 5 a}$ & U/Mg Beds & 3,710 & 8.4 & 442 \\
\hline $\mathrm{B} 5 \mathrm{~b}$ & Hydride/Catalyst/Zeolite Beds & 55 & 0.14 & 393 \\
\hline B6 & Spent TPBARs & 16,000 & 14 & 1,143 \\
\hline B6a & TPBAR Baseplates & 2,270 & 5 & 454 \\
\hline B7 & Furnace Components & 3,400 & 2.5 & 1,360 \\
\hline B7a & $\begin{array}{c}\text { Nonhazardous Equipment } \\
\text { (Extraction) }\end{array}$ & 6,800 & 5 & 1,360 \\
\hline B8 & HEPA Filters (Extraction) & 0 & 0 & - \\
\hline B13 & Tritiated Oil & 360 & 0.4 & 900 \\
\hline B13a & Glovebox Bubbler Fluid & 5.4 & 0.006 & 700 \\
\hline $\mathrm{B} 16$ & $\begin{array}{l}\text { Palladium/Electrolysis } \\
\text { Membrane }\end{array}$ & 0 & 0 & - \\
\hline B17 & Ion Exchange Resin & 0 & 0 & - \\
\hline & Total & $90,170.4$ & 420.45 & 214 \\
\hline
\end{tabular}




\section{CLWR-TEF Mired Low-level Waste Streams}

\begin{tabular}{|c|l|r|r|r|}
\hline $\begin{array}{c}\text { Waste Stream } \\
\text { Number }\end{array}$ & \multicolumn{1}{|c|}{$\begin{array}{c}\text { Waste Stream } \\
\text { Description }\end{array}$} & $\begin{array}{c}\text { Mass } \\
\mathbf{k g} / \mathrm{yr}\end{array}$ & $\begin{array}{c}\text { Volume } \\
\mathrm{m}^{3} / \mathrm{yr}\end{array}$ & $\begin{array}{c}\text { Bulk Density } \\
\mathbf{k g} / \mathrm{m}^{3}\end{array}$ \\
\hline B4 & Job Control Waste (Mixed) & 760 & 5 & 152 \\
\hline B9 & Mixed Equipment & 23 & 0.01 & 2,300 \\
\hline B10 & Mixed/Hazardous Waste Oil & 0 & 0 & - \\
\hline B11 & Mixed Solvent Rags & 0 & 0 & - \\
\hline B12 & $\begin{array}{l}\text { Analytical/Rad Con } \\
\text { Chemicals }\end{array}$ & $*$ & $*$ & - \\
\hline B15 & Teledyne Micro-fuel Cells & 6.8 & 0.04 & 1,700 \\
\hline & Total & 789.8 & 5.014 & 157.5 \\
\hline
\end{tabular}

*Assume most chemicals will be disposed as hazardous waste. As mixed waste, they are covered in the other mixed waste streams: B4, B10, and B11.

\section{CLWR-TEF Hazardous Waste Streams}

\begin{tabular}{|c|l|r|r|r|}
\hline $\begin{array}{c}\text { Waste Stream } \\
\text { Number }\end{array}$ & \multicolumn{1}{|c|}{$\begin{array}{c}\text { Waste Stream } \\
\text { Description }\end{array}$} & $\begin{array}{c}\text { Mass } \\
\mathbf{k g} / \mathbf{y r}\end{array}$ & $\begin{array}{c}\text { Volume } \\
\mathbf{m}^{3 / y r}\end{array}$ & $\begin{array}{c}\text { Bulk Density } \\
\mathbf{k g} / \mathbf{m}^{\mathbf{3}}\end{array}$ \\
\hline B10 & Mixed/Hazardous Waste Oil & 0 & 0 & - \\
\hline B12 & AnalyticalRad Con Chemicals & 1,256 & 1.3 & 966 \\
\hline B15 & Teledyne Micro-fuel Cells & 4.5 & 0.004 & 1,125 \\
\hline & Total & $1,260.5$ & 1.304 & 966.4 \\
\hline
\end{tabular}




\section{CLWR-TEF Radioactive Liquid Waste Streams}

\begin{tabular}{|c|l|r|r|c|}
\hline $\begin{array}{c}\text { Waste Stream } \\
\text { Number }\end{array}$ & \multicolumn{1}{|c|}{$\begin{array}{c}\text { Waste Stream } \\
\text { Description }\end{array}$} & $\begin{array}{c}\text { Mass } \\
\text { kg/yr }\end{array}$ & $\begin{array}{c}\text { Volume } \\
\mathbf{m}^{3} / \mathbf{y r}\end{array}$ & $\begin{array}{c}\text { Bulk Density } \\
\mathbf{k g} / \mathbf{m}^{3}\end{array}$ \\
\hline B10 & Mixed/Hazardous Waste Oil & 0 & 0 & - \\
\hline B13 & Tritiated Oil & 180 & 0.2 & 900 \\
\hline B14 & $\begin{array}{l}\text { Tritiated Water and Aqueous } \\
\text { Solutions }\end{array}$ & 41,800 & 41.8 & 1,000 \\
\hline & Total & 41,980 & 42 & 1,000 \\
\hline
\end{tabular}




\section{APPENDIX E}

\section{Waste Stream Inventory by Type and Source - EIS Format}

The EIS groups waste streams by type (low-level radioactive waste, mixed low-level waste or hazardous waste) and source. Normally the source refers to the various project options. Since this PWA is focused on the CLWR-TEF Project, the source will refer to either the front-end TPBAR receipt and extraction or the back-end tritium processing. 


\section{Summary - EIS Data}

Low-Level Radioactive Waste

\begin{tabular}{|l|c|c|c|}
\hline \multicolumn{1}{|c|}{ Process Waste } & $\begin{array}{c}\text { Mass } \\
\mathbf{k g} / \mathbf{y r}\end{array}$ & $\begin{array}{c}\text { Volume } \\
\mathbf{m}^{\mathbf{3}} / \mathbf{y r}\end{array}$ & $\begin{array}{c}\text { Bulk Density } \\
\mathbf{k g} / \mathbf{m}^{\mathbf{3}}\end{array}$ \\
\hline TPBAR Extraction Waste & 68,470 & 326.5 & 210 \\
\hline Tritium Processing & 21,700 & 93.95 & 231 \\
\hline TOTAL & 90,170 & 420.45 & 214 \\
\hline
\end{tabular}

Mixed Low-Level Waste

\begin{tabular}{|l|c|c|c|}
\hline \multicolumn{1}{|c|}{ Process Stream } & $\begin{array}{c}\text { Mass } \\
\mathbf{k g} / \mathbf{y r}\end{array}$ & $\begin{array}{c}\text { Volume } \\
\mathbf{m}^{\mathbf{3}} / \mathbf{y r}\end{array}$ & $\begin{array}{c}\text { Bulk Density } \\
\mathbf{k g} / \mathbf{m}^{\mathbf{3}}\end{array}$ \\
\hline TPBAR Extraction Waste & $\mathbf{3 9 1 . 5}$ & 2.505 & 156 \\
\hline Tritium Processing & 398.3 & 2.545 & 156 \\
\hline TOTAL & $\mathbf{7 8 9 . 8}$ & $\mathbf{5 . 0 5}$ & $\mathbf{1 5 6}$ \\
\hline
\end{tabular}

Hazardous Waste

\begin{tabular}{|l|r|c|c|}
\hline \multicolumn{1}{|c|}{ Process Stream } & $\begin{array}{c}\text { Mass } \\
\mathbf{k g} / \mathrm{yr}\end{array}$ & $\begin{array}{c}\text { Volume } \\
\mathrm{m}^{3} / \mathrm{yr}\end{array}$ & $\begin{array}{c}\text { Bulk Density } \\
\mathrm{kg}^{\mathbf{3}} \mathbf{m}^{3}\end{array}$ \\
\hline TPBAR Extraction Waste & 628 & 0.65 & 966 \\
\hline Tritium Processing & 632.5 & 0.654 & 967 \\
\hline TOTAL & $\mathbf{1 2 6 0 . 5}$ & 1.304 & 966 \\
\hline
\end{tabular}

Radioactive Liquid Waste

\begin{tabular}{|l|c|c|c|}
\hline \multicolumn{1}{|c|}{ Process Stream } & $\begin{array}{c}\text { Mass } \\
\mathbf{k g} / \mathbf{y r}\end{array}$ & $\begin{array}{c}\text { Volume } \\
\mathbf{m}^{3} / \mathbf{y r}\end{array}$ & $\begin{array}{c}\text { Bulk Density } \\
\mathbf{k g} / \mathbf{m}^{\mathbf{3}}\end{array}$ \\
\hline TPBAR Extraction Waste & 38,000 & 38 & 1000 \\
\hline Tritium Processing & 3,980 & 4 & 1000 \\
\hline TOTAL & $\mathbf{4 1 , 9 8 0}$ & $\mathbf{4 2}$ & 1000 \\
\hline
\end{tabular}


CLWR-TEF TPBAR Extraction Waste - Data for EIS

Low-Level Radioactive Waste Streams

\begin{tabular}{|c|l|r|r|r|}
\hline $\begin{array}{c}\text { Waste Stream } \\
\text { Number }\end{array}$ & \multicolumn{1}{|c|}{$\begin{array}{c}\text { Waste Stream } \\
\text { Description }\end{array}$} & $\begin{array}{c}\text { Mass } \\
\mathbf{k g} / \mathrm{yr}\end{array}$ & $\begin{array}{c}\text { Volume } \\
\mathbf{m}^{\mathbf{3}} / \mathrm{yr}\end{array}$ & $\begin{array}{c}\text { Bulk Density } \\
\mathbf{k g} / \mathrm{m}^{3}\end{array}$ \\
\hline B3 & Job Control Waste (Extraction) & 40,000 & 300 & 133 \\
\hline B6 & Spent TPBARs & 16,000 & 14 & 1,143 \\
\hline B6a & TPBAR Baseplates & 2,270 & 5 & 454 \\
\hline B7 & Furnace Components & 3,400 & 2.5 & 1,360 \\
\hline B7a & $\begin{array}{c}\text { Nonhazardous Equipment } \\
\text { (Extraction) }\end{array}$ & 6,800 & 5 & 1,360 \\
\hline B8 & HEPA Filters (Extraction) & 0 & 0 & - \\
\hline & Total & 68,470 & 326.5 & 210 \\
\hline
\end{tabular}

\section{Mired Low-level Waste Streams}

\begin{tabular}{|c|l|r|r|r|}
\hline $\begin{array}{c}\text { Waste Stream } \\
\text { Number }\end{array}$ & \multicolumn{1}{|c|}{$\begin{array}{c}\text { Waste Stream } \\
\text { Description }\end{array}$} & $\begin{array}{c}\text { Mass } \\
\mathbf{k g} / \mathbf{y r}\end{array}$ & $\begin{array}{c}\text { Volume } \\
\mathrm{m}^{3} / \mathbf{y r}\end{array}$ & $\begin{array}{c}\text { Bulk Density } \\
\mathbf{k g} / \mathrm{m}^{3}\end{array}$ \\
\hline B4 & Job Control Waste (Mixed) & 380 & 2.5 & 152 \\
\hline B9 & Mixed Equipment & 11.5 & 0.005 & 2,300 \\
\hline B10 & Mixed/Hazardous Waste Oil & 0 & 0 & - \\
\hline B11 & Mixed Solvent Rags & 0 & 0 & - \\
\hline B12 & $\begin{array}{c}\text { Analytical/Rad Con } \\
\text { Chemicals }\end{array}$ & $*$ & $*$ & - \\
\hline & Total & 391.5 & 2.505 & 156 \\
\hline
\end{tabular}

*Assume most chemicals will be disposed as hazardous waste. As mixed waste, they are covered in the other mixed waste streams: B4, B10, and B11. 


\section{Hazardous Waste Stream}

\begin{tabular}{|c|l|c|c|c|}
\hline $\begin{array}{c}\text { Waste Stream } \\
\text { Number }\end{array}$ & \multicolumn{1}{|c|}{$\begin{array}{c}\text { Waste Stream } \\
\text { Description }\end{array}$} & $\begin{array}{c}\text { Mass } \\
\mathbf{k g} / \mathrm{yr}\end{array}$ & $\begin{array}{c}\text { Volume } \\
\mathrm{m}^{3 / y r}\end{array}$ & $\begin{array}{c}\text { Bulk Density } \\
\mathbf{k g} / \mathbf{m}^{3}\end{array}$ \\
\hline B12 & Analytical/Rad Con Chemicals & 628 & 0.65 & 966 \\
\hline & Total & 628 & 0.65 & 966. \\
\hline
\end{tabular}

\section{Radioactive Liquid Waste Streams}

\begin{tabular}{|c|l|r|r|c|}
\hline $\begin{array}{c}\text { Waste Stream } \\
\text { Number }\end{array}$ & \multicolumn{1}{|c|}{$\begin{array}{c}\text { Waste Stream } \\
\text { Description }\end{array}$} & $\begin{array}{c}\text { Mass } \\
\mathbf{k g} / \mathbf{y r}\end{array}$ & $\begin{array}{c}\text { Volume } \\
\mathbf{m}^{\mathbf{3}} / \mathbf{y r}\end{array}$ & $\begin{array}{c}\text { Bulk Density } \\
\mathbf{k g} / \mathbf{m}^{\mathbf{3}}\end{array}$ \\
\hline B10 & Mixed/Hazardous Waste Oil & 0 & 0 & - \\
\hline B14 & $\begin{array}{l}\text { Tritiated Water and Aqueous } \\
\text { Solutions }\end{array}$ & 38,000 & 38 & 1,000 \\
\hline & Total & 38,000 & 38 & 1,000 \\
\hline
\end{tabular}




\section{CLWR-TEF Tritium Processing Waste - Data for EIS}

\section{Low-Level Radioactive Waste Streams}

\begin{tabular}{|c|c|c|c|c|}
\hline $\begin{array}{c}\text { Waste Stream } \\
\text { Number }\end{array}$ & $\begin{array}{l}\text { Waste Stream } \\
\text { Description }\end{array}$ & $\begin{array}{l}\text { Mass } \\
\mathrm{kg} / \mathrm{yr}\end{array}$ & $\begin{array}{c}\text { Volume } \\
\mathbf{m}^{3} / \mathbf{y r}\end{array}$ & $\begin{array}{c}\text { Bulk Density } \\
\mathrm{kg} / \mathrm{m}^{3}\end{array}$ \\
\hline$\overline{\mathrm{B} 1}$ & Job Control Waste (H-3) & 10,000 & 75 & 133 \\
\hline$\overline{\text { B2 }}$ & Job Control Waste (Uranium) & 770 & 5 & 154 \\
\hline$\overline{\mathrm{B} 5}$ & Nonhazardous Equipment (H-3) & 6,800 & 5 & 1,360 \\
\hline$\overline{B 5 a}$ & U/Mg Beds & 3,710 & 8.4 & 442 \\
\hline$\overline{\text { B5b }}$ & Hydride/Catalyst/Zeolite Beds & 55 & 0.14 & 393 \\
\hline$\overline{B 13}$ & Tritiated Oil & 360 & 0.4 & 900 \\
\hline$\overline{B 13 a}$ & Glovebox Bubbler Fluid & $\overline{5.4}$ & 0.006 & 700 \\
\hline$\overline{\mathrm{B} 16}$ & $\begin{array}{l}\text { Palladium/Electrolysis } \\
\text { Membrane }\end{array}$ & $\overline{0}$ & 0 & - \\
\hline \multirow[t]{2}{*}{$\overline{\text { B17 }}$} & Ion Exchange Resin & 0 & 0 & - \\
\hline & $\overline{\text { Total }}$ & 21,700 & 93.95 & 231 \\
\hline
\end{tabular}




\section{Mired Low-level Waste Streams}

\begin{tabular}{|c|l|r|r|r|}
\hline $\begin{array}{c}\text { Waste Stream } \\
\text { Number }\end{array}$ & \multicolumn{1}{|c|}{$\begin{array}{c}\text { Waste Stream } \\
\text { Description }\end{array}$} & $\begin{array}{c}\text { Mass } \\
\mathbf{k g} / \mathbf{y}\end{array}$ & $\begin{array}{c}\text { Volume } \\
\mathbf{m}^{\mathbf{3}} / \mathbf{y r}\end{array}$ & $\begin{array}{c}\text { Bulk Density } \\
\mathbf{k g} / \mathbf{m}^{3}\end{array}$ \\
\hline B4 & Job Control Waste (Mixed) & 380 & 2.5 & 152 \\
\hline B9 & Mixed Equipment & 11.5 & 0.005 & 2,300 \\
\hline B10 & Mixed/Hazardous Waste Oil & 0 & 0 & - \\
\hline B11 & Mixed Solvent Rags & 0 & 0 & - \\
\hline B12 & Analytical/Rad Con Chemicals & $*$ & $*$ & - \\
\hline B15 & Teledyne Micro-fuel Cells & 6.8 & 0.04 & 1,700 \\
\hline & Total & 398.3 & 2.545 & 156 \\
\hline
\end{tabular}

*Assume most chemicals will be disposed as hazardous waste. As mixed waste, they are covered in the other mixed waste streams: B4, B10, and B11.

Haxardous Waste Streams

\begin{tabular}{|c|l|r|r|c|}
\hline $\begin{array}{c}\text { Waste Stream } \\
\text { Number }\end{array}$ & \multicolumn{1}{|c|}{$\begin{array}{c}\text { Waste Stream } \\
\text { Description }\end{array}$} & $\begin{array}{c}\text { Mass } \\
\mathbf{k g} / \mathbf{y r}\end{array}$ & $\begin{array}{c}\text { Volume } \\
\mathbf{m}^{\mathbf{3}} / \mathbf{y r}\end{array}$ & $\begin{array}{c}\text { Bulk Density } \\
\mathbf{k g} / \mathbf{m}^{\mathbf{3}}\end{array}$ \\
\hline B10 & Mixed/Hazardous Waste Oil & 0 & 0 & - \\
\hline B12 & Analytical/Rad Con Chemicals & 628 & 0.65 & 966 \\
\hline B15 & Teledyne Micro-fuel Cells & 4.5 & 0.004 & 1,125 \\
\hline & Total & $\mathbf{6 3 2 . 5}$ & $\mathbf{0 . 6 5 4}$ & 967 \\
\hline
\end{tabular}

\section{Radioactive Liquid Waste Streams}

\begin{tabular}{|c|l|r|r|r|}
\hline $\begin{array}{c}\text { Waste Stream } \\
\text { Number }\end{array}$ & \multicolumn{1}{|c|}{$\begin{array}{c}\text { Waste Stream } \\
\text { Description }\end{array}$} & $\begin{array}{c}\text { Mass } \\
\mathbf{k g} / \mathbf{y r}\end{array}$ & $\begin{array}{c}\text { Volume } \\
\mathbf{m}^{\mathbf{3}} / \mathbf{y r}\end{array}$ & $\begin{array}{c}\text { Bulk Density } \\
\mathbf{k g} / \mathbf{m}^{\mathbf{3}}\end{array}$ \\
\hline B10 & Mixed/Hazardous Waste Oil & 0 & 0 & - \\
\hline B13 & Tritiated Oil & 180 & 0.2 & 900 \\
\hline B14 & $\begin{array}{l}\text { Tritiated Water and Aqueous } \\
\text { Solutions }\end{array}$ & 3,800 & 3.8 & 1,000 \\
\hline & Total & 3,980 & 4 & 1,000 \\
\hline
\end{tabular}




\section{APPENDIX F \\ Waste Stream Inventory by Waste Treatment Category}

Appendix $F$ lists the masses $(\mathrm{kg})$, volumes $\left(\mathrm{m}^{3}\right)$ and bulk densities $\left(\mathrm{kg} / \mathrm{m}^{3}\right)$ for each low-level radioactive waste, mixed low-level waste and hazardous waste stream by waste treatment category and disposal option. Several waste streams have multiple treatment/disposal options available, based on waste form and radionuclide content. These options are discussed in detail for each waste stream in Appendix B. 
Incineration and Stabilization of Residue

\section{A. Low-Level Radioactive Waste}

\begin{tabular}{|c|c|c|c|c|}
\hline $\begin{array}{c}\text { Waste Stream } \\
\text { Number }\end{array}$ & $\begin{array}{l}\text { Waste Stream } \\
\text { Description }\end{array}$ & $\begin{array}{l}\text { Mass } \\
\text { ke/yr }\end{array}$ & $\begin{array}{c}\text { Volume } \\
\mathrm{m}^{3} / \mathrm{yr}\end{array}$ & $\begin{array}{c}\text { Bulk Density } \\
\mathbf{k g} / \mathrm{m}^{3}\end{array}$ \\
\hline B1 & Job Control Waste (H-3) & 10,000 & 75 & 133 \\
\hline $\mathbf{B 2}$ & Job Control Waste (Uranium) & 770 & 5 & 154 \\
\hline$\overline{\text { B3 }}$ & $\begin{array}{l}\text { Job Control Waste } \\
\text { (Extraction) }\end{array}$ & 20,000 & 150 & 133 \\
\hline B13 & Tritiated Oil & 180 & 0.20 & 900 \\
\hline $\mathbf{B 1 3 a}$ & Glovebox Bubbler Fluid & 1.8 & 0.002 & 900 \\
\hline Total & & $30,951.8$ & 230.2 & 134 \\
\hline
\end{tabular}

\section{B. Mired Low-level Waste}

\begin{tabular}{|c|c|c|c|c|}
\hline $\begin{array}{c}\text { Waste Stream } \\
\text { Number }\end{array}$ & $\begin{array}{c}\text { Waste Stream } \\
\text { Description }\end{array}$ & $\begin{array}{c}\text { Mass } \\
\mathbf{k g} / \mathbf{y r}\end{array}$ & $\begin{array}{c}\text { Volume } \\
\mathbf{m}^{\mathbf{3}} / \mathbf{y r}\end{array}$ & $\begin{array}{c}\text { Bulk Density } \\
\mathbf{k g} / \mathbf{m}^{\mathbf{3}}\end{array}$ \\
\hline B1 & Job Control Waste (Mixed) & 380 & 2.5 & 152 \\
\hline Total & & 380 & 2.5 & 152 \\
\hline
\end{tabular}

\section{Hazardous Waste}

\begin{tabular}{|c|l|c|c|c|}
\hline $\begin{array}{c}\text { Waste Stream } \\
\text { Number }\end{array}$ & \multicolumn{1}{|c|}{$\begin{array}{c}\text { Waste Stream } \\
\text { Description }\end{array}$} & $\begin{array}{c}\text { Mass } \\
\text { kg/yr }\end{array}$ & $\begin{array}{c}\text { Volume } \\
\mathbf{m}^{\mathbf{3}} / \mathbf{y r}\end{array}$ & $\begin{array}{c}\text { Bulk Density } \\
\mathbf{k g} / \mathbf{m}^{\mathbf{3}}\end{array}$ \\
\hline B10 & Mixed/Hazardous Oil & - & - & - \\
\hline B12 & $\begin{array}{l}\text { Analytical Lab/Rad Con } \\
\text { Chemicals* }\end{array}$ & 82 & 0.09 & 900 \\
\hline Total & & 82 & 0.09 & 900 \\
\hline
\end{tabular}

*Includes approximately $180 \mathrm{lb}$. (82 kg) of pump oil from Appendix B Waste Stream B12 inventory list. A Specific Gravity of $0.9\left(900 \mathrm{~kg} / \mathrm{m}^{3}\right)$ for oil is assumed. 


\section{Compaction for EAV LAW Vault Disposal}

\section{A. Low-Level Radioactive Waste}

\begin{tabular}{|c|l|c|c|c|}
\hline $\begin{array}{c}\text { Waste Stream } \\
\text { Number }\end{array}$ & \multicolumn{1}{|c|}{$\begin{array}{c}\text { Waste Stream } \\
\text { Description }\end{array}$} & $\begin{array}{c}\text { Mass } \\
\text { kg/yr }\end{array}$ & $\begin{array}{c}\text { Volume } \\
\mathbf{m}^{\mathbf{3}} / \mathbf{y r}\end{array}$ & $\begin{array}{c}\text { Bulk Density } \\
\mathbf{k g} / \mathbf{m}^{3}\end{array}$ \\
\hline B3 & $\begin{array}{l}\text { Job Control Waste } \\
\text { (Extraction) }\end{array}$ & 10,000 & 75 & 133 \\
\hline Total & & 10,000 & 75 & 133 \\
\hline
\end{tabular}

Direct Disposal to LAW Vaults

\section{A. Low-Level Radioactive Waste}

\begin{tabular}{|c|c|c|c|c|}
\hline $\begin{array}{c}\text { Waste Stream } \\
\text { Number }\end{array}$ & $\begin{array}{l}\text { Waste Stream } \\
\text { Description }\end{array}$ & $\begin{array}{l}\text { Mass } \\
\text { kg/yr }\end{array}$ & $\begin{array}{c}\text { Volume } \\
\mathrm{m}^{3} / \mathrm{yr}\end{array}$ & $\begin{array}{c}\text { Bulk Density } \\
\mathbf{k g} / \mathrm{m}^{3}\end{array}$ \\
\hline B3 & $\begin{array}{l}\text { Job Control Waste } \\
\text { (Extraction) }\end{array}$ & 10,000 & 75 & 133 \\
\hline B5 & Equipment (H-3) & 3,400 & 2.5 & 1,360 \\
\hline B5b & Hydride Beds & 55 & 0.14 & 393 \\
\hline B7a & Equipment (Extraction) & 3,400 & 2.5 & 1,360 \\
\hline B13 & Tritiated Oil* & 360 & 0.4 & 900 \\
\hline $\mathbf{B 1 3 a}$ & Glovebox Bubbler Fluid* & 3.6 & 0.004 & 900 \\
\hline Total & & $17,218.6$ & 80.54 & 214 \\
\hline
\end{tabular}

*These liquids are stabilized before disposal.

\section{Direct Disposal to ILTV Silos}

\section{A. Low-Level Radioactive Waste (Intermediate Level Waste)}

\begin{tabular}{|c|l|c|c|c|}
\hline $\begin{array}{c}\text { Waste Stream } \\
\text { Number }\end{array}$ & \multicolumn{1}{|c|}{$\begin{array}{c}\text { Waste Stream } \\
\text { Description }\end{array}$} & $\begin{array}{c}\text { Mass } \\
\mathbf{k g} / \mathbf{y r}\end{array}$ & $\begin{array}{c}\text { Volume } \\
\mathbf{m}^{\mathbf{3}} / \mathbf{y r}\end{array}$ & $\begin{array}{c}\text { Bulk Density } \\
\mathbf{k g} / \mathbf{m}^{\mathbf{3}}\end{array}$ \\
\hline B6 & Spent TPBARs (Extraction) & 16,000 & 14 & 1143 \\
\hline B6a & TPBAR Baseplates & 2,270 & 5 & 454 \\
\hline Total & & 18,270 & 19 & 962 \\
\hline
\end{tabular}

Direct Disposal to ILTV Bulk Cell

A. Low-Level Radioactive Waste (Intermediate Level Waste) 


\begin{tabular}{|c|l|c|c|c|}
\hline $\begin{array}{c}\text { Waste Stream } \\
\text { Number }\end{array}$ & \multicolumn{1}{|c|}{$\begin{array}{c}\text { Waste Stream } \\
\text { Description }\end{array}$} & $\begin{array}{c}\text { Mass } \\
\mathbf{k g} / \mathbf{y r}\end{array}$ & $\begin{array}{c}\text { Volume } \\
\mathbf{m}^{3} / \mathrm{yr}\end{array}$ & $\begin{array}{c}\text { Bulk Density } \\
\mathbf{k g} / \mathbf{m}^{\mathbf{3}}\end{array}$ \\
\hline B5 & Equipment (H-3) & 3,400 & 2.5 & 1,360 \\
\hline B5a & U/Mg Beds & 3,710 & 8.4 & 442 \\
\hline B7 & Furnace Components & 3,400 & 2.5 & 1,360 \\
\hline B7a & Equipment (Extraction) & 3,400 & 2.5 & 1,360 \\
\hline Total & & 13,910 & 15.9 & 875 \\
\hline
\end{tabular}

Interim Storage/Off-site Disposal

B. Mixed Low-Level Waste

\begin{tabular}{|c|l|c|c|c|}
\hline $\begin{array}{c}\text { Waste Stream } \\
\text { Number }\end{array}$ & \multicolumn{1}{|c|}{$\begin{array}{c}\text { Waste Stream } \\
\text { Description }\end{array}$} & $\begin{array}{c}\text { Mass } \\
\mathbf{k g} / \mathbf{y r}\end{array}$ & $\begin{array}{c}\text { Volume } \\
\mathbf{m}^{\mathbf{3}} / \mathbf{y r}\end{array}$ & $\begin{array}{c}\text { Bulk Density } \\
\mathbf{k g} / \mathbf{m}^{3}\end{array}$ \\
\hline B4 & Job Control Waste (Mixed) & 380 & 2.5 & 152 \\
\hline B9 & Mixed Waste Equipment & 23 & 0.01 & 2,300 \\
\hline B15 & $\begin{array}{l}\text { Oxygen Analyzer Micro-fuel } \\
\text { Cells }\end{array}$ & 6.8 & 0.004 & 1,700 \\
\hline Total & & 409.8 & 2.514 & $\sim 163$ \\
\hline
\end{tabular}

\section{Hazardous Waste}

\begin{tabular}{|c|l|c|c|c|}
\hline $\begin{array}{c}\text { Waste Stream } \\
\text { Number }\end{array}$ & \multicolumn{1}{|c|}{$\begin{array}{c}\text { Waste Stream } \\
\text { Description }\end{array}$} & $\begin{array}{c}\text { Mass } \\
\mathrm{kg} / \mathrm{yr}\end{array}$ & $\begin{array}{c}\text { Volume } \\
\mathrm{m}^{3} / \mathrm{yr}\end{array}$ & $\begin{array}{c}\text { Bulk Density } \\
\mathrm{kg} / \mathrm{m}^{3}\end{array}$ \\
\hline B12 & $\begin{array}{l}\text { Analytical Lab/Rad Con } \\
\text { Chemicals* }\end{array}$ & 628 & 0.63 & 1,000 \\
\hline B15 & $\begin{array}{l}\text { Oxygen Analyzer Micro-fuel } \\
\text { Cells }\end{array}$ & 4.5 & 0.004 & 1,125 \\
\hline Total & & 632.5 & 0.63 & 1,000 \\
\hline
\end{tabular}

*Analytical Laboratory/Rad Con chemicals are wastes for which treatments cannot a priori be defined. Treatment will be a function of the type of chemical; e.g., solid, liquid, acid, base, etc. Most chemicals are assumed to be clean non-radioactive waste and can be recycled or shipped to an off-site vendor for processing. The number shown here is approximate, excluding pump oils and alcohols. A specific gravity of 1 is assumed. 


\section{APPENDIX G}

\section{LPA Hazardous Waste Codes With Subcategories}

Table G1 below lists EPA hazardous waste codes for which EPA has developed subcategories (40 CFR sections 268.41 through 268.43, Tables CCWE, 2, 3, and CCW). For each subcategory, DOE has assigned a letter subcode. The subcategories represent unique Land Disposal Restrictions (LDR) treatability groups with distinct treatment standards. In addition, DOE has assigned a subcategory (with subcode " $X$ ") for wastes that, because of a lack of characterization information, could not be put into an appropriate EPA defined subcategory. This table was developed in support of the SRS Approved Site Treatment Plan for mixed waste, WSRC-TR-940608, and may be subject to change. 
Table G1

EPA Hazardous Waste Codes with Subcategories defined under the LDRs Program

\begin{tabular}{|c|c|c|c|c|}
\hline $\begin{array}{l}\text { MPA } \\
\text { Code }\end{array}$ & $\begin{array}{l}\text { Sub } \\
\text { code }\end{array}$ & Subcategory & Conc Limit & Description \\
\hline \multirow[t]{3}{*}{ D001 } & $A$ & $\begin{array}{l}\text { Ignitable Liquids High TOC } \\
\text { Nonwastewaters }\end{array}$ & & $\begin{array}{l}\text { Ignitable liquids as defined in } 40 \mathrm{CFR} \\
261.21 \text { containing } 10 \% \text { or greater } \\
\text { Total Organic Carbon (TOC). }\end{array}$ \\
\hline & $\overline{\mathbf{B}}$ & Ignitable Liquids, Wastewaters & & $\begin{array}{l}\text { Ignitable wastes as identified in } 40 \\
\text { CFR } 261.21 \text { managed as wastewater } \\
\text { [e.g., in Clean Water Act surface } \\
\text { impoundments or land disposal units } \\
\text { (or their equivalent); or in Safe } \\
\text { Drinking Water Act underground } \\
\text { injection wells]. }\end{array}$ \\
\hline & $\bar{C}$ & $\begin{array}{l}\text { Ignitable Waste, Low TOC } \\
\text { Nonwastewaters }\end{array}$ & & $\begin{array}{l}\text { All other ignitable waste as identified } \\
\text { in } 40 \text { CFR } 261.21 \text { that is neither a } \\
\text { high TOC nor managed as } \\
\text { wastewater. }\end{array}$ \\
\hline \multirow[t]{3}{*}{$\mathrm{DO02}$} & $\overline{\mathbf{A}}$ & $\begin{array}{l}\text { Corrosive Wastewater-Acid, } \\
\text { Alkaline or Other }\end{array}$ & & $\begin{array}{l}\text { Corrosive waste, as identified in } 40 \\
\text { CFR 261.22, managed as wastewater. } \\
\text { [e.g., in Clean Water Act surface } \\
\text { impoundments or land disposed units } \\
\text { (or their equivalent); or in Safe } \\
\text { Drinking Water Act underground } \\
\text { injection wells.] }\end{array}$ \\
\hline & $\bar{B}$ & $\begin{array}{l}\text { Corrosive Nonwastewater-Acid, } \\
\text { Alkaline or Other }\end{array}$ & & $\begin{array}{l}\text { Corrosive waste, as identified in } 40 \\
\text { CFR 261.22, not managed as } \\
\text { wastewater. }\end{array}$ \\
\hline & $\overline{\mathbf{C}}$ & High-Level Wastes & & $\begin{array}{l}\text { Wastes that exhibit the properties } \\
\text { listed in } 40 \mathrm{CFR} 261.22 \text { (a)(1) and are } \\
\text { radioactive high-level wastes } \\
\text { generated during the reprocessing of } \\
\text { nuclear fuel rods. }\end{array}$ \\
\hline
\end{tabular}


Table G1

EPA Hazardous Waste Codes with Subcategories defined under the LDRs Program (Cont'd)

\begin{tabular}{|c|c|c|c|c|}
\hline $\begin{array}{l}\text { IPA } \\
\text { Code }\end{array}$ & $\begin{array}{l}\text { Sub } \\
\text { code }\end{array}$ & Subcategory & Conc Limit & Description \\
\hline \multirow[t]{5}{*}{$\mathrm{DO03}$} & $\mathbf{A}$ & Reactive Cyanides & & $\begin{array}{l}\text { Cyanide-bearing wastes that, when } \\
\text { exposed to pH conditions between } 2 \\
\text { and } 12.5 \text {, generate hazardous } \\
\text { quantities of toxic gases. }\end{array}$ \\
\hline & B & Reactive Sulfides & & $\begin{array}{l}\text { Sulfide-bearing wastes that, when } \\
\text { exposed to } \mathrm{pH} \text { conditions between } 2 \\
\text { and } 12.5 \text {, generate hazardous } \\
\text { quantities of toxic gases. }\end{array}$ \\
\hline & $\mathrm{C}$ & Explosives & & $\begin{array}{l}\text { Waste capable of detonation or } \\
\text { explosive reaction under various } \\
\text { conditions, or is a forbidden, Class A } \\
\text { or Class B explosive under DOT } \\
\text { regulations. }\end{array}$ \\
\hline & D & Water Reactives & & $\begin{array}{l}\text { Waste, as defined in } 40 \text { CFR } \\
261.23(a)(2) \text {, (3), or (4), that is either } \\
\text { very reactive with water, or is capable } \\
\text { of generating toxic or explosive gases } \\
\text { with water. }\end{array}$ \\
\hline & $\overline{\mathbf{E}}$ & Other Reactives & & $\begin{array}{l}\text { Reactive waste that, per } 40 \text { CFR } \\
261.23(a)(1) \text {, is normally unstable and } \\
\text { readily under goes violent change } \\
\text { without detonating. }\end{array}$ \\
\hline \multirow[t]{2}{*}{ D004 } & $\overline{\mathbf{A}}$ & TCLP Toxic for Arsenic & $5.0 \mathrm{mg} / \mathrm{l}$ & $\begin{array}{l}\text { Those wastes that exhibit the toxicity } \\
\text { characteristics for arsenic. }\end{array}$ \\
\hline & $\bar{B}$ & As High-Level Wastes & & $\begin{array}{l}\text { Those wastes that exhibit the toxicity } \\
\text { characteristics for arsenic and are } \\
\text { radioactive high-level wastes } \\
\text { generated during the reprocessing of } \\
\text { nuclear fuel rods. }\end{array}$ \\
\hline \multirow[t]{2}{*}{ D005 } & $\overline{\mathbf{A}}$ & TCLP Toxic for Barium & $100 \mathrm{mg} /$ & $\begin{array}{l}\text { Those wastes that exhibit the toxicity } \\
\text { characteristics for barium. }\end{array}$ \\
\hline & $\mathbf{B}$ & Ba High-Level Wastes & & $\begin{array}{l}\text { Those wastes that exhibit the toxicity } \\
\text { characteristics for barium and are } \\
\text { radioactive high-level wastes } \\
\text { generated during the reprocessing of } \\
\text { nuclear fuel rods. }\end{array}$ \\
\hline D006 & $\mathbf{A}$ & TCLP Toxic for Cadmium & $1.0 \mathrm{mg} / \mathrm{l}$ & $\begin{array}{l}\text { Those wastes that exhibit the toxicity } \\
\text { characteristic for cadmium. }\end{array}$ \\
\hline
\end{tabular}


Table G1

EPA Hazardous Waste Codes with Subcategories defined under the LDRs Program (Cont'd)

\begin{tabular}{|c|c|c|c|c|}
\hline $\begin{array}{l}\text { EPA } \\
\text { Code }\end{array}$ & $\begin{array}{l}\text { Sub } \\
\text { code }\end{array}$ & Subcategory & Conc Limit & Description \\
\hline \multirow[t]{2}{*}{ D006 } & B & Cadmium-containing batteries & & $\begin{array}{l}\text { Batteries containing leachable levels } \\
\text { of cadmium above } 1.0 \mathrm{mg} / \mathrm{iter} \text {. }\end{array}$ \\
\hline & $\bar{C}$ & Cd High-Level Wastes & & $\begin{array}{l}\text { Those wastes that exhibit the toxicity } \\
\text { characteristics for cadmium and are } \\
\text { radioactive high-level wastes } \\
\text { generated during the reprocessing of } \\
\text { nuclear fuel rods. }\end{array}$ \\
\hline \multirow[t]{2}{*}{ D007 } & $\bar{A}$ & TCLP Toxic for Chromium & $5.0 \mathrm{mg} / 1$ & $\begin{array}{l}\text { Those wastes that exhibit the toxicity } \\
\text { characteristic for cadmium. }\end{array}$ \\
\hline & B & Cr High-Level Wastes & & $\begin{array}{l}\text { Those wastes that exhibit the toxicity } \\
\text { characteristics for chromium and are } \\
\text { radioactive high-level wastes } \\
\text { generated during the reprocessing of } \\
\text { nuclear fuel rods. }\end{array}$ \\
\hline \multirow[t]{4}{*}{ D008 } & $\mathbf{A}$ & TCLP Toxic for Lead & $5.0 \mathrm{mg} /$ & $\begin{array}{l}\text { Those wastes that exhibit the toxicity } \\
\text { characteristic for lead. }\end{array}$ \\
\hline & B & Lead Acid Batteries & & $\begin{array}{l}\text { Lead acid batteries that are identified } \\
\text { as RCRA hazardous wastes and which } \\
\text { are not excluded from regulation } \\
\text { under the land disposal restrictions. }\end{array}$ \\
\hline & C & Radioactive Lead Solids & & $\begin{array}{l}\text { Lead solids, including elemental } \\
\text { forms of lead, but not including } \\
\text { treatment residuals that can be } \\
\text { stabilized or organo-lead materials } \\
\text { that can be incinerated (then } \\
\text { stabilized as ash). }\end{array}$ \\
\hline & $\overline{\mathbf{D}}$ & Po High-Level Wastes & & $\begin{array}{l}\text { Those wastes that exhibit the toxicity } \\
\text { characteristics for lead and are } \\
\text { radioactive high-level wastes } \\
\text { generated during the reprocessing of } \\
\text { nuclear fuel rods. }\end{array}$ \\
\hline \multirow[t]{2}{*}{ D009 } & $\bar{A}$ & TCLP Toxic for Mercury & $0.2 \mathrm{mg} / 1$ & $\begin{array}{l}\text { Nonwastewaters that exhibit the } \\
\text { toxicity characteristic for mercury and } \\
\text { contain less than } 260 \mathrm{mg} / \mathrm{kg} \text { total } \\
\text { mercury. }\end{array}$ \\
\hline & $\mathbf{B}$ & $\begin{array}{l}\text { High Mercury (Contains } \\
\text { Organics) }\end{array}$ & & $\begin{array}{l}\text { Nonwastewaters that exhibit the } \\
\text { toxicity characteristic for mercury, } \\
\text { contain greater than or equal to } 260 \\
\text { mg/kg total mercury, also contain } \\
\text { organics, and are not incinerator } \\
\text { residues. }\end{array}$ \\
\hline
\end{tabular}




\section{Table G1}

\section{EPA Hazardous Waste Codes with Subcategories defined under the LDRs Program} (Cont'd)

\begin{tabular}{|c|c|c|c|c|}
\hline $\begin{array}{l}\text { EPA } \\
\text { Code }\end{array}$ & $\begin{array}{l}\text { Sub } \\
\text { code }\end{array}$ & Subcategory & Conc Limit & Description \\
\hline \multirow[t]{5}{*}{ D009 } & C & $\begin{array}{l}\text { High Mercury (Contains } \\
\text { Inorganics) }\end{array}$ & & $\begin{array}{l}\text { Nonwastewaters that exhibit the } \\
\text { toxicity characteristic for mercury, } \\
\text { contain greater than or equal to } 260 \\
\text { mg/kg total mercury, are inorganic, } \\
\text { and may include incinerator residues } \\
\text { and residues from mercury roasting } \\
\text { and retorting (RMERC) operations. }\end{array}$ \\
\hline & D & $\begin{array}{l}\text { Elemental Mercury Contaminated } \\
\text { with Radioactive Materials }\end{array}$ & & $\begin{array}{l}\text { Elemental mercury contaminated with } \\
\text { radioactive materials. }\end{array}$ \\
\hline & $\bar{E}$ & $\begin{array}{l}\text { Hydraulic Oil Contaminated with } \\
\text { Mercury Radioactive Materials }\end{array}$ & & $\begin{array}{l}\text { Hydraulic oil exhibiting the toxicity } \\
\text { characteristic for mercury and which } \\
\text { is contaminated with radioactive } \\
\text { materials. }\end{array}$ \\
\hline & $\bar{F}$ & Mercuny Wastewaters & & $\begin{array}{l}\text { All D009 waste managed as } \\
\text { wastewater. }\end{array}$ \\
\hline & $\bar{X}$ & $\begin{array}{l}\text { Nonwastewater with Unknown } \\
\text { Mercury Concentration }\end{array}$ & & $\begin{array}{l}\text { Characteristically hazardous mixed } \\
\text { wastes due to mercury that are not } \\
\text { elementary mercury, hydraulic oil or } \\
\text { high-level waste, for which it is not } \\
\text { known if the mercury concentration is } \\
\text { less than or equal to } 260 \text { ppm. }\end{array}$ \\
\hline \multirow[t]{2}{*}{ D010 } & $\overline{\mathbf{A}}$ & TCLP Toxic for Selenium & $5.7 \mathrm{mg} / \mathrm{l}$ & $\begin{array}{l}\text { Those wastes that exhibit the toxicity } \\
\text { characteristics for selenium. }\end{array}$ \\
\hline & $\overline{\mathbf{B}}$ & Se High-Level Wastes & & $\begin{array}{l}\text { Those wastes that exhibit the toxicity } \\
\text { characteristics for selenium and are } \\
\text { radioactive high-level wastes } \\
\text { generated during the reprocessing of } \\
\text { nuclear fuel rods. }\end{array}$ \\
\hline \multirow[t]{2}{*}{$\overline{D 011}$} & $\bar{A}$ & TCLP Toxic for Silver & $5.0 \mathrm{mg} / \mathrm{l}$ & $\begin{array}{l}\text { Those wastes that exhibit the toxicity } \\
\text { characteristics for silver. }\end{array}$ \\
\hline & $\overline{\mathbf{B}}$ & Ag High-Lovel Wastes & & $\begin{array}{l}\text { Those wastes that exhibit the toxicity } \\
\text { characteristics for silver and are } \\
\text { radioactive high-level wastes } \\
\text { generated during the reprocessing of } \\
\text { nuclear fuel rods. }\end{array}$ \\
\hline
\end{tabular}




\section{Table G1}

EPA Hazardous Waste Codes with Subcategories defined under the LDRs Program (Cont'd)

\begin{tabular}{|c|c|c|c|c|}
\hline $\begin{array}{l}\text { EPA } \\
\text { Code }\end{array}$ & $\begin{array}{l}\text { Sub } \\
\text { code }\end{array}$ & Subcategory & Conc Limit & Description \\
\hline \multirow[t]{2}{*}{$\mathrm{F} 003$} & $A$ & Spent Nonhalogenated Solvents & $\begin{array}{l}2.6-180 \\
\mathrm{mg} / 1\end{array}$ & $\begin{array}{l}\text { F003 solvent due to the presence of } \\
\text { one of the following: acetone, ethyl } \\
\text { acetate, ethyl benzene, ethyl ether, } \\
\text { methyl isobutyl ketone, n-Butyl } \\
\text { alcohol, and xylene. Also } \\
\text { cyclohexane, but only if F001-F005 } \\
\text { solvents other than methanol and/or } \\
\text { carbon disulfide (F005) are also } \\
\text { present. Also methanol, but only if } \\
\text { F001-F005 solvents other than } \\
\text { cyclohexane and/or carbon disulfide } \\
\text { (F005) are also present. }\end{array}$ \\
\hline & B & $\begin{array}{l}\text { Cyclohexane/Methanol/Carbon } \\
\text { Disulfide Only }\end{array}$ & & $\begin{array}{l}\text { F003 solvent due to the presence of } \\
\text { cyclohexane, methanol or carbon } \\
\text { disulfide, but only if no other F001- } \\
\text { F005 solvents are present (except } \\
\text { cyclohexane, methanol and/or carbon } \\
\text { disulfide are also present). }\end{array}$ \\
\hline \multirow[t]{4}{*}{ F005 } & $\mathbf{A}$ & Spent Nonhalogenated Solvents & $\begin{array}{c}10-170 \\
\mathrm{mg} / 1\end{array}$ & $\begin{array}{l}\text { The following spent non-halogenated } \\
\text { solvents: benzene, isobutanol, } \\
\text { methylethyl ketone, pyridine, and } \\
\text { toluene. Also, carbon disulfide if } \\
\text { FO01-F005 solvents other than } \\
\text { cyclohexane (F003) and/or methanol } \\
\text { (F003) are also present. Also, 2- } \\
\text { Ethoxyethanol and 2-Nitropropane, } \\
\text { but only if other F001-F005 solvents } \\
\text { are also present. }\end{array}$ \\
\hline & B & $\begin{array}{l}\text { Solvent Waste Listed for } 2 \text { - } \\
\text { Nitropropane only }\end{array}$ & & $\begin{array}{l}\text { Waste containing 2-nitropropane as } \\
\text { the only F001-F005 listed solvent. }\end{array}$ \\
\hline & C & $\begin{array}{l}\text { Solvent Waste Listed for } 2- \\
\text { Ethoxyethanol only }\end{array}$ & & $\begin{array}{l}\text { Waste containing } 2 \text {-ethoxyethanol as } \\
\text { the only F001-F005 listed solvent. }\end{array}$ \\
\hline & $\overline{\mathbf{D}}$ & $\begin{array}{l}\text { Cyclohexane/Methanol/Carbon } \\
\text { Disulfide only }\end{array}$ & & $\begin{array}{l}\text { F005 listed mixed waste for which the } \\
\text { specific F005 constituent is not } \\
\text { identified. } \\
\text { F005 solvent due to the presence of } \\
\text { carbon disulfide, but only if no other } \\
\text { F001-F005 solvents are present, } \\
\text { except that cyclohexane (F003) and/or } \\
\text { methanol (F003) may also be present. }\end{array}$ \\
\hline
\end{tabular}




\section{Table G1}

\section{EPA Hazardous Waste Codes with Subcategories defined under the LDRs Program (Cont'd)}

\begin{tabular}{|c|c|c|c|c|}
\hline $\begin{array}{l}\text { EPA } \\
\text { Code }\end{array}$ & $\begin{array}{l}\text { Sub } \\
\text { code }\end{array}$ & Subcategory & Conc Limit & Description \\
\hline \multirow[t]{2}{*}{ F025 } & $\mathbf{A}$ & F025 Light Ends & & $\begin{array}{l}\text { Light ends listed for one or more of } \\
\text { the following: Carbon Tetrachloride; } \\
\text { chloroform; 1, 2-Dichloroethane; 1, 1- } \\
\text { Dichloroethylene; methylene chloride; } \\
\text { 1, 1, 2-Trichloroethane; Trichloethane } \\
\text { or vinyl chloride; plus wastes } \\
\text { qualifying as F025 light ends, but } \\
\text { characterization information is } \\
\text { insufficient to determine specific } \\
\text { contaminants. }\end{array}$ \\
\hline & $\mathbf{B}$ & Spent Filter/Aids and Desiocants & & $\begin{array}{l}\text { Spent filters/aids containing one or } \\
\text { more of the following: Carbon } \\
\text { tetrachloride, chloroform, methylene } \\
\text { chloride, 1, 1,2-Trichloraethane, } \\
\text { Trichloroethylene, vinyl chloride, } \\
\text { hexachlorobutadiene, or } \\
\text { hexachloroethane, plus wastes } \\
\text { qualifying as F025 spent filters/aids or } \\
\text { desiccants, but characterization is } \\
\text { insufficient to determine specific } \\
\text { contaminants. }\end{array}$ \\
\hline \multirow[t]{2}{*}{ P047 } & $\bar{A}$ & 4, 6-Dinitro-a-cresol & & $\begin{array}{l}\text { 4, 6-Dinitro-o-cresol as a discarded } \\
\text { commercial chemical product, off- } \\
\text { specification species, container } \\
\text { residue, or spill residue. }\end{array}$ \\
\hline & $\overline{\mathbf{B}}$ & 4, 6-Dinitro-o-cresol salts & & $\begin{array}{l}\text { 4, 6-Dinitro-o-cresol salts as } \\
\text { discarded commercial chemical } \\
\text { products, off-specification species, } \\
\text { container residues, or spill residues. }\end{array}$ \\
\hline \multirow[t]{2}{*}{ P059 } & $\overline{\mathbf{A}}$ & Heptachlor & & $\begin{array}{l}\text { Heptachlor as a discarded commercial } \\
\text { chemical product, off-specification } \\
\text { species, container residuc, or spill } \\
\text { residue. }\end{array}$ \\
\hline & B & Heptachlor Epaxide & & $\begin{array}{l}\text { Heptachlor epoxide as a discarded } \\
\text { commercial chemical product, off- } \\
\text { specification species, container } \\
\text { residue, or spill residuc. }\end{array}$ \\
\hline
\end{tabular}




\section{Table G1}

\section{EPA Hazardous Waste Codes with Subcategories defined under the LDRs Program (Cont'd)}

\begin{tabular}{|c|c|c|c|c|}
\hline $\begin{array}{l}\text { EPA } \\
\text { Code }\end{array}$ & $\begin{array}{l}\text { Sub } \\
\text { code }\end{array}$ & Subcategory & Cone Limit & Description \\
\hline \multirow[t]{5}{*}{ P065 } & $\mathbf{A}$ & $\begin{array}{l}\text { Mercury Fulminate - High } \\
\text { Mercury Incinerator or RMERC } \\
\text { Residues }\end{array}$ & & $\begin{array}{l}\text { Nonwastewaters with greater than or } \\
\text { equal to } 260 \mathrm{mg} / \mathrm{kg} \text { total mercury and } \\
\text { that are residues from either } \\
\text { incineration or mercury roasting or } \\
\text { retorting (RMRRC) of wastes } \\
\text { containing mercury fulminate. }\end{array}$ \\
\hline & $\bar{B}$ & $\begin{array}{l}\text { Mercury Fulminate Waste (not } \\
\text { from incineration or RMERC) }\end{array}$ & & $\begin{array}{l}\text { Nonwastewater mercury fulminate } \\
\text { waste, regardless of mercury content } \\
\text { that is neither residues from } \\
\text { incineration nor residues from } \\
\text { RMERC. }\end{array}$ \\
\hline & $\bar{C}$ & $\begin{array}{l}\text { Mercury Fulminate - Low } \\
\text { Mercury RMERC Residues }\end{array}$ & & $\begin{array}{l}\text { Nonwastewaters with less than } 260 \\
\text { mg/kg total mercury and that are } \\
\text { residues from RMERC of wastes } \\
\text { containing mercury fulminate. }\end{array}$ \\
\hline & $\overline{\mathbf{D}}$ & $\begin{array}{l}\text { Mercury Fulminate - Low } \\
\text { Mercury Incinerator Residues (not } \\
\text { RMERC) }\end{array}$ & & $\begin{array}{l}\text { Nonwastewaters with less than } 260 \\
\text { mg/kg total mercury and that are } \\
\text { residues from RMERC of wastes } \\
\text { containing mercury fulminate. }\end{array}$ \\
\hline & $\overline{\mathbf{E}}$ & Mercury Fulminate Wastewaters & & $\begin{array}{l}\text { All P065 (mercury fulminate) waste } \\
\text { managed as wastewaters. }\end{array}$ \\
\hline \multirow[t]{3}{*}{ P092 } & $\bar{A}$ & $\begin{array}{l}\text { Phenyl Mercury Acetate } \\
\text { Nonwastewater } \\
\text { High Mercury Incinerator or } \\
\text { RMERC Residues }\end{array}$ & & $\begin{array}{l}\text { Nonwastewaters phenyl mercury } \\
\text { acetate wastes, regardless of mercury } \\
\text { content, that are residues from either } \\
\text { incineration or mercury roasting or } \\
\text { retorting (RMERC) of wastes } \\
\text { containing phenyl mercury acetate. }\end{array}$ \\
\hline & B & $\begin{array}{l}\text { Phenyl Mercury Acetate } \\
\text { Nonwastewater } \\
\text { Phenyl Mencury Acetate Waste } \\
\text { (not from incineration or } \\
\text { RMERC) }\end{array}$ & & $\begin{array}{l}\text { Nonwastewaters phenyl mercury } \\
\text { scetate wastes, regardless of mercury } \\
\text { content, that are residues from } \\
\text { incineration nor residues from } \\
\text { RMERC. }\end{array}$ \\
\hline & C & $\begin{array}{l}\text { Phenyl Mercury Acetate } \\
\text { Nonwastewater } \\
\text { Low Mercury RMRRC Residues }\end{array}$ & & $\begin{array}{l}\text { Nonwastewaters with less than } 260 \\
\text { mg/kg total mercury and that are } \\
\text { residues from RMERC of wastes } \\
\text { containing phenyl mercury acetate. }\end{array}$ \\
\hline
\end{tabular}




\section{Table G1}

EPA Hazardous Waste Codes with Subcategories defined under the LDRs Program (Cont'd)

\begin{tabular}{|c|c|c|c|c|}
\hline $\begin{array}{l}\text { EPA } \\
\text { Code }\end{array}$ & $\begin{array}{l}\text { Sub } \\
\text { code }\end{array}$ & Subcategory & Conc Limit & Description \\
\hline \multirow[t]{2}{*}{ P092 } & D & $\begin{array}{l}\text { Phenyl Mercury Acetate } \\
\text { Nonwastewaters } \\
\text { Low Mercury Incinerator } \\
\text { Residues (not RMERC) }\end{array}$ & & $\begin{array}{l}\text { Nonwastewaters with less than } 260 \\
\text { mg/kg total mercury and that are } \\
\text { residues from incineration, but not } \\
\text { RMERC, of waste containing phenyl } \\
\text { mercury acetate. }\end{array}$ \\
\hline & $\bar{E}$ & $\begin{array}{l}\text { Phenyl Mercury Acetate } \\
\text { Wastewaters }\end{array}$ & & $\begin{array}{l}\text { All P092 (mercury fulminate) waste } \\
\text { managed as wastewaters. }\end{array}$ \\
\hline \multirow[t]{5}{*}{ U151 } & $\bar{A}$ & High Mercury Nonwastewater & & $\begin{array}{l}\text { Nonwastewaters with greater than or } \\
\text { equal to } 260 \mathrm{mg} / \mathrm{kg} \text { total mercury } \\
\text { [including residues from mercury } \\
\text { roasting or retorting (RMERC) of } \\
\text { U151 waste if it contains greater than } \\
\text { or equal to } 260 \mathrm{mg} / \mathrm{kg} \text { total mercury]. }\end{array}$ \\
\hline & B & $\begin{array}{l}\text { Low Mercury Nonwastewaters } \\
\text { from RMERC }\end{array}$ & & $\begin{array}{l}\text { Nonwastewaters with less than } 260 \\
\text { mg/kg total mercury and that are } \\
\text { residues from RMERC of U151 } \\
\text { wastes. }\end{array}$ \\
\hline & $\mathbf{C}$ & Low Mercury Nonwastewaters & & $\begin{array}{l}\text { Nonwastewaters with less than } 260 \\
\text { mg/kg total mercury that are not } \\
\text { residues from RMERC. }\end{array}$ \\
\hline & $\bar{D}$ & $\begin{array}{l}\text { Elemental Mercury } \\
\text { Contaminated with Radioactive } \\
\text { Materials }\end{array}$ & & \\
\hline & $\overline{\mathbf{E}}$ & Mercury Wastewaters & & $\begin{array}{l}\text { All U151 (mercury) waste managed as } \\
\text { wastewaters. }\end{array}$ \\
\hline \multirow[t]{3}{*}{ U240 } & $\overline{\mathbf{A}}$ & $\begin{array}{l}\text { 2, 4-D (also known as } \\
\text { Dichlorophenoxyacetic Acid) }\end{array}$ & & $\begin{array}{l}\text { 2, 4-D as a discarded commercial } \\
\text { chemical product, off-specification } \\
\text { species, container residues, or spill } \\
\text { residues. }\end{array}$ \\
\hline & $\mathbf{B}$ & $\begin{array}{l}\text { 2, 4-D (Dichlorophenoxyacetic } \\
\text { Acids) Salts \& Esters }\end{array}$ & & $\begin{array}{l}\text { 2, 4-D salts or esters as discarded } \\
\text { commercial chemical products, off- } \\
\text { specification species, container } \\
\text { residues, or spill residues. }\end{array}$ \\
\hline & $\mathbf{C}$ & Unspecified U240 Waste & & $\begin{array}{l}\text { U240 waste, but characterization } \\
\text { information is insufficient to } \\
\text { determine whether the A or B subcode } \\
\text { is appropriate. }\end{array}$ \\
\hline
\end{tabular}


WSRC-TR-96-294, Rev. 1, 11/30/97

"CLWR-TEF Process Waste Assessment"

\section{DISTRIBUTION}

Susan D. Carson, SNL-NM

Phyllis K. Peterson, SNL-NM

Elliot A. Clark, 773-A

G. Jack Alexander, 235-H

Alexcia O. Delley, 730-1B

Jeffrey S. Holder, 232-H

Rex N. Lutz, 773-53A

Robert A. Malstrom, 773-A

Anita S. Poore, 773-A

Paul J. Rowan, 233-26H

Joseph K. Santos, 233-26H

Richard R. Viviano, 730-1B

Ronnie J. Catoe, 730-1B

Michael O. Hickman, 730-1B

Richard Boyd, 233-4H

F. Houston Brown, 730-1B

G. Tom Seeley, 730-1B

Dennis E. Grove, 730-1B

Bill F. Brizes, 730-B

Bob A. Smith, 730-B

John R. Purucker, 730-B

George R. Vozniak, 730-B

Don J. Green, 235-H

Bob L. Rabun, 235-H

James R. Knight, 773-A

B. Tom Butcher, 773-43A

David A. Zigelman, 705-3C

Michael W. Lewis, 724-15E

Maurice J. Ades, 705-3C

Kevin L. Tempel, 705-3C

Ted Motyka, 773-A

James E. Klein, 773-A

B. Tom Butcher, 773-43A

C. Barry Shedrow, 773-42A

Richard W. Reynolds, 703-45A

SRS Records, 773-52A 